Thiago Fernandes dos Santos Pereira

\title{
Ação da Cidadania:
}

Betinho e sua concepção de democracia

Dissertação de Mestrado

Dissertação apresentada ao Programa de PósGraduação em Ciências Sociais da Pontifícia Universidade Católica do Rio de Janeiro (PUCRio) como requisito parcial para a obtenção do título de mestre em Ciências Sociais.

Orientadora: Profạ . Maria Sarah da Silva Telles Co-orientador: Prof. Fernando Cardoso Lima Neto 
Thiago Fernandes dos Santos Pereira

\author{
Ação da Cidadania: \\ Betinho e sua concepção de democracia
}

Dissertação apresentada como requisito parcial para obtenção do grau de Mestre pelo Programa de Pós-Graduação em Ciências Sociais do Departamento de Ciências Sociais do Centro de Ciências Sociais da PUC-Rio. Aprovada pela Comissão Examinadora abaixo assinada.

Profa. Maria Sarah da Silva Telles

Orientadora

Departamento de Ciências Sociais - PUC-Rio

Prof. Fernando Cardoso Lima Neto Co-Orientador

Departamento de Ciências Sociais - PUC-Rio

Profa. Dulce Chaves Pandolfi Fundação Getúlio Vargas

Profa. Angela Maria de Randolpho Paiva Departamento de Ciências Sociais - PUC-Rio

Profa. Mônica Herz

Coordenadora Setorial do Centro de Ciências Sociais - PUC-Rio

Rio de Janeiro, 17 de abril de 2015 
Todos os direitos reservados. É proibida a reprodução total ou parcial do trabalho sem autorização da universidade, do autor e do orientador.

Thiago Fernandes dos Santos Pereira

Graduou-se em Ciências Sociais pela PUC-Rio em 2011e em Pedagogia pela UERJ, em 2012. Especializou-se em Filosofia Moderna e Contemporânea pela UERJ, em 2012. É Professor de Sociologia na Rede Pública estadual do Rio de Janeiro. Tem interesse em Teoria Social Clássica, Sociologia Política e Sociologia da Educação.

Ficha Catalográfica 
Dedico este trabalho a todos os que lutaram e lutam pela superação das injustiças e para que a democracia e seus direitos valham para todos. 


\section{Agradecimentos}

Esta dissertação, apesar de ganhar seu acabamento final a partir de meus punhos, jamais teria sido desenvolvida sem a preciosa ajuda das pessoas que, cada qual com sua parcela, foram muito importantes para o desenvolvimento deste trabalho.

Agradeço a Deus por me conceder vida, paz e amor pela vida.

Agradeço especialmente a minha querida orientadora Maria Sarah da Silva Telles que desde sempre acreditou em mim (as vezes até mais que eu mesmo), sendo desde o início de minha graduação, uma incansável estimuladora de meu desenvolvimento acadêmico e profissional. Por me permitir "ganhar asas", alimentando minhas ideias e projetos sempre com uma acolhida generosa. Sem abdicar do rigor inerente à construção de um trabalho acadêmico, encontrar seu apoio para o desenvolvimento de minhas propostas de análises, me encheu de confiança para concluir este trabalho.

Agradeço também a meu co-orientador Fernando, de quem tenho o prazer de ser seu primeiro orientando no Departamento. Encontrá-lo foi uma grata e feliz surpresa. Agradeço por sua presença e constante cuidado com que sempre analisou o desenvolvimento deste trabalho, sendo um importante mestre e referencial para mim.

Agradeço as integrantes de minha banca, a professora Angela Paiva pelo aceite ao convite e o cuidado demonstrado desde a qualificação com este trabalho e também a professora Dulce Pandolfi, que de pronto aceitou nosso convite e, desde o exame de qualificação deu contribuições inestimáveis para o desenvolvimento deste trabalho, sobretudo na sugestão das análises das correspondências da população à Betinho, que ajudou a iluminar os caminhos propostos neste trabalho, além de dividir conosco experiências maravilhosas sobre Betinho. 
Agradeço a meus professores Maria Alice Rezende de Carvalho, Valter Sinder, Marcelo Burgos e Luiz Werneck Viana com os quais tive o privilégio de dividir momentos de imersão na teoria e pesquisa sociológica e aprendizados que transcendem o universo da sala de aula.

Agradeço a PUC-Rio e a Coordenação de Aperfeiçoamento de Pessoal de Nível Superior (CAPES), pelos auxílios concedidos, sem os quais este trabalho não poderia ter sido realizado.

Agradeço também aos funcionários do CPDOC/FGV pela gentileza e disponibilidade com a qual me trataram, facilitando em muito o labor de minha pesquisa.

Agradeço a meus colegas de curso Irineu, Marcele, Luisa, Luzia, Laura, Christian e Leo Puglia pela boa companhia e por fazerem de nossa convivência sempre agradável, apesar das muitas obrigações a cumprir. Aqueles dias de aula regados aos biscoitinhos, cafés e boas conversas jamais serão esquecidos.

Agradeço a Monica e Eveline pela disponibilidade e gentileza e especialmente a Ana, pelo tratamento sempre cheio de irreverências.

Agradeço aos meus amigos Luiz Antonio e Camila pela força e carinho com que me ajudaram a fazer com que minhas obrigações no curso fossem cumpridas.

Agradeço especialmente a meu amigo e parceiro Leo Ramos pela amizade e apoio em todos os momentos. E também por seu rigor nas correções de meu trabalho e pelas contribuições super importantes que ajudou a agregar neste trabalho.

Agradeço especialmente a meus familiares, sobretudo meus pais Sergio e Erinete que fizeram o carinho e a esperança serem abundantes em nossa convivência e também a Juliane, ao Pedro e a Sara por sempre me ajudarem e apoiarem e me fazerem feliz ao seu lado. 


\section{Resumo}

Thiago Fernandes dos Santos Pereira; Maria Sarah da Silva Telles. Ação da Cidadania: Betinho e sua concepção de democracia. Rio de Janeiro, 2015, 139 p. Dissertação de Mestrado - Departamento de Ciências Sociais, Pontifícia Universidade Católica do Rio de Janeiro.

Este trabalho busca analisar a Campanha da Ação da Cidadania Contra a Fome, a Miséria e Pela Vida, procurando examiná-la além do combate à fome, forma pela qual ficou majoritariamente conhecida no imaginário coletivo. Partindo desta premissa, ao longo do trabalho, percebe-se que tanto o discurso da Campanha - o inconformismo com a fome e a miséria - quanto sua forma de organização, realizada pela sociedade - isto é, fora das instituições tradicionais constituem a materialização de uma forma de pensamento que se desenvolveu décadas antes com seu principal articulador: Herbert de Souza. Conceitos como a importância da sociedade civil, de uma democracia que esteja baseada em princípios como solidariedade e participação social constituem ideias que Betinho reivindica após seu regresso do exílio e que tomam forma na experiência da Campanha da Ação da Cidadania.

\section{Palavras chave}

Ação da cidadania; democracia. 


\section{Abstract}

Thiago Fernandes dos Santos Pereira; Maria Sarah da Silva Telles. Ação da Cidadania: Betinho's conception of democracy, Rio de Janeiro, 2015, 139 p. MSc. Dissertation - Departamento de Ciências Sociais, Pontifícia Universidade Católica do Rio de Janeiro.

This dissertation search analyse the "Campanha da Ação da Cidadania Contra a fome, a miséria e pela Vida" wanting undestand your discorse beyond the fight against hunger. Starting this point, across this dissertation is discovered that the discourse - the rejection against the hunger and poverty - and your organization form - made by the society, out the traditional institutions - are the result the materialization a way of thinking developed for your leader: Herbert de Souza. Concepts such as importance of civil society, of democracy formed by solidarity and social participation are ideas that Herbert de Souza defend after your return from exile and that took place in the experience of Campaingn.

\section{Keywords}

Citizenship action; democracy. 


\section{Sumário}

1. Introdução

2. Encontro de Betinho com seu conceito de democracia

2.1. Betinho, sua vida, suas lutas

2.2. A experiência do exílio: o momento determinante na vida de Betinho

2.2.1. Mudar o Estado para mudar a sociedade: lutas e ações políticas de Betinho anteriores ao exílio

2.2.2. A experiência do Chile e a descoberta de uma outra forma de ação política

2.3. Betinho e sua concepção de democracia

2.4. Incompatibilidade entre capitalismo e democracia

3. Ação da cidadania como desdobramento da descoberta da sociedade civil

3.1. Sociedade civil para Hegel, Marx e Gramsci

3.2. Sociedade civil no contexto contemporâneo

3.3. Sociedade civil no contexto brasileiro

3.4. Ideia de Sociedade civil inspiradora de Betinho

3.5. Ênfase de Betinho na sociedade civil conduzindo-o à

Campanha contra a fome

3.6. Prática cidadã como valor na experiência de Betinho

3.7. Experiência da campanha da Ação da Cidadania Contra a Fome, a Miséria e Pela Vida

3.7.1 A campanha como primeiro passo de uma longa jornada 78

3.7.2. Chamamento ético-político 
3.7.3. Abrangência, organização e adesão

3.7.4. Incompatibilidade entre democracia e miséria

3.8. Campanha como momento exemplar de aposta na sociedade 89

3.9. Campanha como proposta de radicalização da democracia 94

4: A Campanha: suas virtudes, defeitos e legado na sociedade $\quad 98$

4.1. Objeções à organização da Campanha 98

4.2. Respostas da sociedade ao chamamento da Campanha 101

4.3. Recepção da sociedade a partir das correspondências da população a Betinho 103

4.4. Distinção entre caridade e solidariedade 115

4.5. Consequências, desdobramentos e legados da Campanha para relação Estado $\times$ Sociedade no Brasil

5. Considerações Finais

6. Referências Bibliográficas 
Introduzir milhares na vida, nas relações, na sociedade brasileira é a questão central da democracia. Não há como fazer democracia só para alguns, como uma ação entre amigos. Não há como escapar desse desafio

Herbert de Souza 


\section{Introdução}

Os grandes eventos históricos que marcam determinada época e chamam a atenção de uma sociedade como um todo em determinado momento, jamais tendem a ser esquecidos. Sua memória, entretanto, por vezes é guardada pelo senso comum sob um único signo, não contemplando sua complexidade.

A "Campanha da Ação da Cidadania Contra a Fome, a Miséria e pela Vida" figura, certamente, no âmbito desses eventos que marcam a sociedade, popularmente lembrada como a "Campanha contra a fome", ou ainda "Campanha do Betinho".

Imortalizada na memória nacional a partir de seu mote principal de ação pela resolução do problema biológico mais urgente e universal, a fome, que constituía, ainda na década de 1990, um grande problema nacional, cuja superação não era priorizada pelos governos.

Entretanto, compreendê-la como somente uma espécie de "Cruzada contra a fome" - ainda que esta tenha seu alto grau de nobreza - constitui uma contundente diminuição de seu projeto em sua dimensão total.

Este trabalho tem como roteiro o exame da experiência da "Campanha da Ação da Cidadania Contra a Fome, a Miséria e Pela Vida", buscando compreender seu projeto - com "P" maiúsculo - de sociedade, cuja luta pelo fim da fome constituía o primeiro estágio de uma longa caminhada.

Na Campanha, a intolerância contra a existência da fome constituía uma expressão de repúdio contra uma estrutura social que é capaz de negar emprego, moradia, inclusão, etc. A fome constituía a "desgraça derradeira" daqueles cujos demais direitos foram negados. Quem chegava a não ter o que comer era porque já não tinha mais nada, ou melhor, tudo já lhe havia sido negado (SOUZA, 1994, p.22 a).

A Campanha, que iniciou suas ações mirando o combate à fome, não era apenas um movimento que denunciava as condições miseráveis de uma significativa 
parcela da população. Entender o que nela existia para além da agenda contra a fome, o legado não lembrado pelo senso comum, é o mergulho analítico proposto neste trabalho.

Lutar contra a fome significava, na perspectiva da Campanha, lutar contra a sociedade que produzia a fome como fenômeno social. Neste itinerário, inevitavelmente, ela se colocava no limiar do questionamento das próprias estruturas sociais existentes, assim como da proposição de novas formas de ação e organização social que não admitissem a exclusão de milhares de pessoas.

É impossível entender o que foi a experiência e o projeto da Ação da Cidadania sem considerar a história de um de seus fundadores e principal articulador, Herbert de Souza, conhecido como Betinho. Indo além, em determinado momento, a biografia de Betinho e a Campanha confundem-se, ficando impossível falar desta sem lembrar-se daquela.

Uma das apostas deste trabalho é que a natureza fundamental presente nos princípios da Campanha contra a Fome só pode ser compreendida se buscada na biografia de Betinho nas três décadas anteriores a ela.

É no contexto da passagem da década de 1960 para a de 1970, momento em que o Brasil se via assolado pelos anos de chumbo da ditadura civil-militar, que Betinho, integrante da Ação Popular (AP), ainda como militante clandestino que nutria a esperança de organizar uma resistência contra o aparato estatal, percebe, após seguidas divergências com a direção desta organização e a queda de diversos companheiros de luta, que o tipo de estratégia proposto pela AP não era o mais eficaz, decidindo pelo exílio (RODRIGUES, 2007, p. 126; SOUZA, 1978, p.90).

Betinho exila-se no Chile, país que vivia um momento de animação das lutas políticas e sociais decorrentes da eleição do governo de Salvador Allende. Chegando lá, reencontrou não apenas muitos de seus companheiros, como também uma nova forma de pensar as lutas e suas próprias ações.

No Chile, Betinho permite-se realizar uma profunda autocrítica sobre suas ações pregressas, percebendo o quanto estava imerso numa luta com poucas condições de alcançar seus objetivos e que tampouco suas ações correspondiam às 
demandas da realidade concreta em que estivera imerso. Tomar o Estado, contando apenas com a boa vontade de algumas centenas de militantes em nome do povo, mas sem o povo, o fez perceber o quanto essas ideias estavam distantes da realidade brasileira daquela época.

O período em que esteve no Chile proporcionou uma profunda reflexão acerca do que era verdadeiramente mobilização popular, sendo sua principal chave de comparação a sua recente experiência no Brasil em que se falava em nome do povo, mas de um povo que estava desmobilizado. No Chile, lugar em que participação popular efervescia, Betinho percebeu que sem o povo, sem a sociedade, não se iria a lugar algum, não se construiria nenhum projeto sólido (SOUZA, 1996, p. 98 b).

A partir deste momento, a noção da importância da participação da sociedade torna-se um valor, uma premissa para Betinho. Mais importante que uma revolução armada de algumas centenas de pessoas que tomasse o Estado em nome do povo era a participação do povo nas grandes questões e nas lutas do dia-a-dia.

Chegar ao Estado só passou a fazer sentido para Betinho se fosse através da participação popular, da sociedade. Nesse momento, nasce também uma nova fé em Betinho, a fé na força da democracia. Não aquela simples democracia representativa, mas uma democracia constituída de solidariedade, de participação, tendo como valor fundamental a cidadania, que se colocasse como instrumento à serviço da edificação de uma nova estrutura social a partir da participação popular (SOUZA, 1996 a).

Quando retorna ao Brasil no fim da década de 70, Betinho traz um novo projeto de transformação social, não mais a tomada do Estado a qualquer custo, mas somente por meio da adesão e da participação da sociedade. Não mais um novo regime pensado por algumas centenas, mas uma democracia vivida e projetada por todos e, acima de tudo baseada na experiência da cidadania.

O engajamento nas lutas através do estímulo à participação da sociedade constitui a grande bandeira de Betinho no contexto da redemocratização. Nessa perspectiva, Betinho integra o Movimento pela Ética na Política que, com 
centenas de outras entidades e forte participação da sociedade, encabeça o movimento pelo impeachment do presidente Fernando Collor.

Vencida a primeira batalha, o movimento buscou não se desfazer de suas atividades. Buscando outra "causa ética", surge o tema da fome. Em março de 1993, as mesmas entidades que formaram o Movimento pela Ética na Política lançam a Campanha da Ação da Cidadania Contra a Fome, a Miséria e pela Vida, da qual Betinho se torna, rapidamente, a figura mais proeminente.

A ideia da Campanha era estimular a participação da sociedade, unir os necessitados aos que podiam de alguma maneira ajudar, sem comandos ou hierarquias. A ideia era não permanecer inerte frente ao escândalo da fome de 32 milhões de pessoas num país rico.

A Campanha a qual Betinho fora seu principal articulador teve não apenas o mérito de denunciar o escândalo da fome de milhares de pessoas, mas de mostrar que a sociedade era ativa, que estava disposta a agir e a lutar. A amplitude da Campanha e a resposta da sociedade ao chamamento foram dignas de aplausos. Nunca, até então, a sociedade abraçara uma causa de forma tão ampla.

A Campanha revelou como a proposta de Betinho, nascida, sobretudo, após seu exílio no Chile, de ênfase na participação da sociedade como principal motor das transformações sociais, encontrava respaldo na realidade concreta.

A Campanha só pôde existir e ter o caráter que teve devido à influência de Betinho. Nesse sentido, sua análise merece ser revisitada sob esta perspectiva, pois o legado da Campanha transcende em muito a forma aparente pela qual ficou conhecida no imaginário.

Como dito anteriormente, este trabalho busca realizar um exame da experiência da Campanha da Ação da Cidadania sob a ótica da possibilidade de compreendêla como expoente de uma tipologia de ação social até então pouco usual no contexto brasileiro: o da mobilização da sociedade.

O fato de não se encontrar diretamente ligada a partido político ou a movimento social específico não tornava sua reivindicação despolitizada. Pelo contrário, como será observado neste trabalho, a Campanha constitui a expressão de uma 
reivindicação política essencialmente questionadora, a saber: a problematização da contínua existência da fome e da miséria em milhares de lares de um país rico.

Analisando a Campanha como o esboço de uma nova ação política, observa-se que ela pode ser mais bem compreendida se analisada à luz da trajetória de seu principal articulador - Herbert de Souza, Betinho - que, em determinado momento histórico de sua vida e de seu país, se permitiu realizar uma autocrítica, passando a reivindicar uma nova forma de ação política que não mais olhasse para o Estado em si mesmo, mas que estabelecia a sociedade como fundamento de todas as mudanças, inclusive do próprio Estado.

Para analisar o legado e impacto da Campanha na sociedade, buscar-se-á refazer o percurso da trajetória biográfica de Betinho para melhor compreender como ela se materializou na Campanha.

O capítulo inicial apresenta a trajetória de Betinho, observando a experiência do exílio como momento fundamental de sua vida, quando surgem novas formas de pensamento e de intervenção em seu horizonte.

São essas "novas ideias" e formas de intervenção, as quais serão apresentadas no decorrer deste trabalho, articuladas a um ideal de democracia composto pela participação popular, da sociedade, que constituem a base do pensamento que ajudou a orientar os valores e objetivos da Campanha.

Betinho classificou o conjunto dessas "novas ideias" que surgiram em seu horizonte como uma troca de visão:

\begin{abstract}
estreita e autoritária em seus métodos, muito dogmática em direção a uma outra visão da política, afastando-me da esquerda clássica. A questão da democracia se torna, cada vez mais, a preocupação central. Em meu espírito, apareceram outros princípios que qualifico de democráticos (SOUZA apud NAKANO, 2000, p.331)
\end{abstract}

Neste trabalho, analisam-se então, os fundamentos da democracia tal como ela foi pensada por Betinho. Além disso, compara-se tal proposta de democracia, que, na visão de Betinho, seria construída pela efetiva participação popular, com a perspectiva de capitalismo que aqui se desenvolveu. 
No segundo capítulo, busca-se problematizar e situar o conceito de sociedade civil, dimensão chave para pensar a nova proposta de ação política de Betinho e a natureza da Campanha da Ação da Cidadania.

Busca-se compreender como a sociedade civil foi situada no pensamento social clássico a partir das análises de Hegel, Marx e Gramsci. Também se analisa, sucintamente, sua problematização no contexto contemporâneo e brasileiro.

Feito isto, observa-se como a perspectiva de sociedade civil reivindicada por Alan Wolfe (1991) traz importantes elementos para pensar a ideia de sociedade civil idealizada por Betinho e, em boa medida, implementada na Campanha da Ação da Cidadania.

É também feita uma análise descritiva da Campanha, buscando reconstituir seus momentos mais importantes. Ao término deste capítulo, observa-se como ela constitui o momento de materialização de uma proposta que acreditava na força do engajamento da sociedade como caminho para a realização das mudanças necessárias ao país.

O terceiro e último capítulo busca analisar como a Campanha mobilizou, atingiu e chamou a atenção da sociedade bem como a forma pela qual compreendeu a mensagem da Campanha. Para isto, utiliza-se, sobretudo, a análise das correspondências da população a Betinho presentes em seu acervo pessoal localizado no Centro de Pesquisa e Documentação (CPDOC) da Fundação Getúlio Vargas (FGV) no Rio de Janeiro. O conjunto das correspondências traz valiosas pistas para entender como, efetivamente, as pessoas compreendiam e respondiam à mensagem da Campanha.

Partindo deste corpus, o trabalho analisa como a Campanha da Ação da Cidadania trouxe novos elementos para pensar a relação Estado x sociedade no Brasil e como estas novas propostas podem ser compreendidas se observada a própria trajetória de seu principal articulador, Betinho. 


\section{2: Encontro de Betinho com seu conceito de democracia}

\subsection{Betinho: sua vida, suas lutas}

Além de constituir um indivíduo singular na história recente do Brasil, Herbert de Souza teve, ao longo de sua existência, para além das notáveis realizações publicamente conhecidas, um conjunto próprio de ideias que guiavam sua práxis. Tais ideias que direcionavam suas ações sofreram, ao longo do tempo, significativas mudanças.

Essas mudanças em sua forma de pensamento constituem também objeto de análise deste trabalho, nas quais a experiência da Campanha da Ação da Cidadania Contra a Fome, a Miséria e Pela Vida é observada como resultante de tais mudanças.

Antes de apresentar alguns conceitos fundamentais que Betinho teve como referência, procuraremos apresentar o personagem central deste trabalho de forma sucinta, buscando identificar os principais eventos de sua vida relacionados aos temas em questão. Para tanto, baseamo-nos em alguns materiais como a biografia de Betinho, escrita por Carla Rodrigues ${ }^{1}$; dois livros/entrevistas, Sem vergonha da utopia: conversas com Betinho, de Ricardo Gontijo e No fio da navalha: Betinho, constituído por um conjunto de jornalistas e um acadêmico ${ }^{2}$; e duas reconstituições da vida e obra de Betinho, organizadas por Dulce Pandolfi ${ }^{3}$.

Betinho nasceu Herbert José de Souza, em 3 de novembro de 1935, na cidade de Bocaiúva, no norte de Minas Gerais. Filho do Seu Henrique e Dona Maria, Betinho teve mais cinco irmãs e dois irmãos. A primeira tragédia na vida da

\footnotetext{
${ }^{1}$ Carla Rodrigues, “Betinho: sertanejo, mineiro, brasileiro”, Ed. Planeta, São Paulo, 2007.

2 "No fio da navalha: Betinho", conjunto de entrevistas reunidas numa publicação. Participaram na condição de entrevistadores: Emir Sader, Fernando Molica, Franklin Martins, Marceu Vieira e Suely Caldas.

3 Dulce Pandolfi e Luciana Heymann: “Um abraço Betinho", Ed. Garamond, Rio de Janeiro, 2005; Dulce Pandolfi, Agusto Gazir e Lucas Correa (Orgs): “O Brasil de Betinho, Mórula Editorial/IBASE, Rio de Janeiro, 2012.
} 
família deu-se no nascimento dos três irmãos que nasceram hemofílicos, doença transmitida pela mãe.

Primeira tragédia na vida de Betinho, a hemofilia com a qual é obrigado a conviver desde o nascimento, priva-o de uma infância considerada "normal", devido às limitações físicas impostas pela doença. A despeito dela, no entanto, a infância de Betinho, apesar de simples, foi carregada de boa convivência com os familiares, em especial com o pai, de quem guarda boas lembranças:

Ele não se parecia nada comigo (...) mas a imagem do meu pai como companheiro vem de longe (...) quando ele chegava em casa, resolvia sempre dar um passeio comigo. Me botava montado em seu cangote e íamos até uma fazenda próxima. Eu acho que esse estar com, passear com e conversar com era a maior demonstração de companheirismo que ele, uma pessoa dos seus trinta e tantos anos, podia dar a uma criança de quatro, cinco anos (SOUZA apud GONTIJO, 1988, p. 33).

Durante a infância, além de viver em Bocaiúva, cidade na qual seu pai chegou a ser nomeado prefeito, entre 1941 e 1943, viveu em Ribeirão das Neves e em Belo Horizonte.

$\mathrm{Na}$ adolescência contraiu tuberculose, doença fatal na época. Pelo alto risco de contágio provocado pela doença, havia apenas dois caminhos: a internação num hospital, ou o isolamento. A família optou pelo segundo, improvisando um quartinho no quintal da casa, onde Betinho viveu isolado durante três anos. Seus contatos eram raros. Durante os três anos em que esteve adoentado, Betinho foi privado do convívio com o mundo exterior, a escola e os amigos.

A cura da tuberculose veio três anos mais tarde, aos 18 anos. Quando o tratamento convencional já não era capaz de oferecer melhoras significativas, o jovem descobriu, em meio a suas leituras - uma das raras companhias para o solitário jovem tuberculoso -, um novo medicamento que prometia a cura da doença. Na Revista "O Cruzeiro", veio a saber sobre a "Hidrazida", medicamento que o curaria em três meses de tratamento.

A cura da tuberculose abriu novamente o mundo e a vida para o jovem que passou a viver intensamente, buscando recuperar os anos perdidos pela doença. 
Voltou, então, a estudar e, como era, em geral, três anos mais velho que seus colegas de turma, alcançou rapidamente proeminência e liderança. Retomou também o contato com a igreja através da militância na Ação Católica através da $\mathrm{JEC}^{4}$, a qual já havia se interessado ainda durante o período de reclusão por conta da doença.

A experiência da Ação Católica representou a possibilidade de mudança no ethos religioso católico que, até então, no Brasil, de maneira geral, tinha uma prática religiosa separada das questões sociais. No contexto da década de 1950, entretanto, inclusive com a inserção da Ação Católica no Brasil, surgiu "um grupo de leigos e parte da hierarquia eclesiástica que estavam propondo uma nova leitura do que [era] ser cristão", de modo a associar a prática religiosa à luta pelas questões sociais (PAIVA, 2003, p. 164).

As leituras de autores ligados ao humanismo cristão como Teilhard de Chardin (1881-1955), Jacques Maritain (1882-1973) e Emmanuel Mounier (1905-1950), que relacionavam a experiência da fé cristã ao engajamento pelos ideais de justiça terrena, constituem, pode-se dizer, o gérmen das ideias de Betinho sobre a sociedade.

Maritain propôs, em sua concepção de humanismo integral, uma ação do indivíduo cristão comprometido como cidadão, classificada como comprometer-se enquanto cristão, afirmando a necessidade dos católicos atuarem de forma engajada no mundo. Esta concepção seria diferente da que o autor classificou como comprometer-se como cristão, o que compreendia se relacionar apenas com as estruturas institucionais da igreja (PAIVA, 2003, p. 168).

Mounier também exerce nesse momento importante influência para esse novo tipo de ação engajada que surgia em alguns espaços na Ação Católica brasileira,

\footnotetext{
${ }^{4}$ Juventude Estudantil Católica. Parte integrante da Ação Católica no Brasil, instituída na década de 1930 pela Igreja Católica objetivando a formação de leigos para colaborar na missão de evangelização da igreja. No bojo desses movimentos são criadas várias instituições setoriais representativas da sociedade. A JEC especificamente tinha como área de atuação os estudantes secundaristas. No entanto, assim como a JEC, a JUC, que atuava no meio universitário, vão receber no Brasil a influência de padres ligados e/ou simpáticos ao humanismo cristão, ajudando a formar uma base de militantes que unisse a prática cristã à militância política. Posteriormente vários militantes chegam a deixar a JEC e a JUC, pelas limitações de suas atuações nos marcos institucionais do clero da Igreja.
} 
associando o modo de ser católico à intolerância com as injustiças no mundo. Em sua concepção, o católico estar indiferente frente aos acontecimentos do mundo constituiria um "escândalo". Este referencial de pensamento exerceu forte influência na direção da JUC nos anos 50 (PAIVA, 2003, p. 170 e 171).

O engajamento e pensamento de Betinho são influenciados sobremaneira por esta literatura, por uma leitura de religiosos que associavam a fé cristã e a prática religiosa: "Maritain, propunha um 'cristianismo jovial e engajado', que pretendia atuar no mundo, e defendia 'uma sociedade democrática, onde justiça, liberdade e fraternidade não fossem apenas palavras, porém realidades vivas, ao alcance de todos" (RODRIGUES, 2007, p.46).

Sua entrada na JEC, que em Belo Horizonte havia sido fundada em 1953, ano de sua cura, coincide com sua entrada no movimento estudantil. Já em 1958, transferiu-se para a JUC ${ }^{5}$, ao ingressar no curso de Administração Pública e Sociologia Política da faculdade de Ciências Econômicas, ligada à Universidade Federal de Minas Gerais.

Sua juventude, no final dos anos 1950 e início dos anos 1960, é marcada por uma intensa atividade estudantil, quando, em 1961, a chapa ligada à JUC elegeu Aldo Arantes para a presidência da União Nacional dos Estudantes (UNE) ${ }^{6}$.

No entanto, conforme se intensificava o aprofundamento de Betinho com a militância, mais apareciam as divergências com as limitações da Ação Católica através da JUC, que, ligada à hierarquia da igreja, via com desconfiança e mesmo oposição o horizonte das lutas sociais sendo articuladas dentro de suas estruturas.

O grupo de Betinho na JUC envolvia-se cada vez mais nas questões sociais e políticas, assim como no questionamento das injustiças presentes na sociedade. Buscando-se desvencilhar das limitações presentes na hierarquia da igreja, acabou por fundar a Ação Popular (AP) que representava a continuidade da mesma luta

\footnotetext{
${ }^{5} \mathrm{JUC}$ (Juventude Universitária Católica), criada e desenvolvida nos mesmos marcos da JEC, tinha como área especifica de atuação o setor universitário.

${ }^{6}$ União Nacional dos Estudantes, entidade estudantil formada em 1938. Ganhou notoriedade pela atuação política combatente desde a década de 1940, quando fez oposição ao Estado Novo. Na década de 1960, opôs-se à ditadura militar e nas campanhas das diretas, nos anos 80 , e no impeachment do presidente Fernando Collor nos anos 90.
} 
inicialmente travada na juventude católica com agendas sociais mais enfáticas e desvinculadas das normas da igreja:

\begin{abstract}
A fundação da AP foi o meio encontrado por essas pessoas para reivindicar a independência com relação à hierarquia eclesiástica, rompendo definitivamente com a igreja. Ainda que fossem preservados traços da filosofia humanista e do pensamento dos católicos franceses, a AP tinha a missão de desenvolver a política nacionalista, a reforma universitária, a defesa da escola pública, a aliança entre estudantes, proletários e camponeses, temas alheios à discussão religiosa (LIMA NETO, 2013, p. 120 e 121).
\end{abstract}

A AP nasceu em 1962 como uma organização política engajada. Já no ano seguinte, elegeu o presidente da UNE, na época José Serra, e tornou-se uma das principais organizações políticas do Brasil. Rapidamente, conquistou amplos setores estudantis, conseguindo, em determinados momentos, mais influência que o próprio Partido Comunista no movimento estudantil. Num espaço de menos de dois anos, a AP ganhou um enorme protagonismo no movimento político brasileiro. Em entrevista de Betinho, Ricardo Gontijo observa que:

Em menos de dois anos de atividade, a AP somava mais de 2 mil militantes em todo país. "Nós éramos um grupo de radicais, mas que em nenhum momento tínhamos entrado em áreas difíceis de conquista cultural. O PC esforçava-se sempre por se auto-afirmar como PC. Isso afastava a massa impregnada de pregação anticomunista. Nós dizíamos o que o PC queria dizer, mas sem usar nenhum slogan. Tínhamos uma maneira de falar que se adaptava ao nosso contexto cultural" (GONTIJO, 1988, p. 69).

Devido a sua proeminência no movimento estudantil e na AP, Betinho é chamado, em 1963, para trabalhar na assessoria do Ministério da Educação sob a gestão do ministro Paulo de Tarso. Apesar de curta, essa experiência é significativa para Betinho. Sobre essa atuação que constitui uma das primeiras experiências no governo e no poder, Betinho afirma:

Foi uma experiência fascinante, era a primeira vez que a gente tinha uma experiência de poder. Então, você chega no ministério da educação e descobre com pouco tempo que aquilo ali era uma clientela, pelo corredor você sabe que é uma clientela, político e Igrejas e escolas particulares. Eu me lembro, por exemplo, de ver o Tancredo lá discutindo o problema de distribuição de lápis, caderno, material escolar, isso tudo era material de propaganda, de campanha eleitoral. E era distribuído lá. O Paulo chama o Paulo Freire e bola a 
Campanha de Alfabetização; ele já tinha o método, a gente resolve alfabetizar um milhão de pessoas (SOUZA, 1996, p. 47 b)

Ao sair do Ministério da Educação junto com o ministro Paulo de Tarso no final de 1963, Betinho foi convidado para trabalhar na SUPRA (Superintendência da Reforma Agrária), pois, é salutar lembrar que a bandeira da luta pela reforma agrária constitui um elemento presente na biografia de Betinho desde sua militância de juventude até sua ação nas décadas de 1980/90. Carla Rodrigues observa, na biografia de Betinho, que, oficialmente, sua atribuição seria a de "montar um plano de reforma para o Brasil e organizar os camponeses", mas ao ser contratado, ganhou a função prática de, "sair pelo Brasil organizando a AP" (RODRIGUES, 2007, p. 88).

As experiências de construção da AP, da reforma agrária e do governo foram, entretanto, interrompidas com o golpe de 1964. Receosos e atemorizados pelos rumores da disposição do governo em iniciar reformas estruturais, como a agrária por exemplo, amplos setores da elite, assim como diversos segmentos religiosos, constituíram uma importante base social de apoio ao golpe de Estado que derrubou o presidente João Goulart.

O golpe, seguido da inexistência de uma resistência organizada, inaugurou um período de duas décadas de supressão de experiência democrática e, mais que isso, interrompeu todos os projetos e caminhos, tanto na esfera do governo, quanto da sociedade, dos movimentos estudantis e populares. Toda a esfera de encaminhamento de lutas dos camponeses, dos trabalhadores, dos estudantes foi trucidada pelo golpe. Realizando análise retrospectiva sobre o significado do golpe, Betinho observa que:

O fim do processo era como ver um pai morto. Havia sido cometido um assassinato político. Ali morreu um Estado, morreu uma liderança popular, morreu um processo. Uma derrota política de um período histórico da qual você jamais vai se recuperar nos mesmos termos. Teria que ser criado um novo Brasil, um novo processo (...). Não haverá uma ressurreição do pré-64, porque esse período foi trucidado, foi assassinado. Não se matam somente as pessoas, também se matam os países, os processos históricos. Agora é preciso reinventar o país e o seu processo (GONTIJO, 1988, p.73). 
Após o golpe, Betinho seguiu para o Uruguai, mesmo destino de dezenas de integrantes do governo e do próprio presidente. No ano seguinte, Betinho retornou ao Brasil clandestinamente com o objetivo de rearticular a AP. As atividades da organização tiveram eficácia relativa, no sentido de encaminhar uma resistência contra a ditadura até 1967. No entanto, não apenas o endurecimento do regime a partir de 1968, mas os problemas e divergências internas da própria organização tornavam seus intentos cada vez mais difíceis de serem realizados (RODRIGUES, 2007, p. 108 e 109).

Após uma longa série de divergências sobre as táticas de ação adotadas pela AP, que decidiu seguir a estratégia da revolução chinesa, adotando preceitos do maoísmo, seus integrantes foram conduzidos a um processo de "proletarização" como forma de construção da resistência.

Betinho foi enviado para São Paulo e, durante algum tempo, trabalhou como operário, tarefa que encontrava dificuldades adicionais devido à fragilidade de sua condição física constantemente afetada pela hemofilia. Além disso, o endurecimento do regime e o enfraquecimento da resistência provocado pelo desmantelamento e captura de vários militantes, somadas as suas crescentes divergências com a direção da AP, levaram Betinho a partir para o exílio em 1971

Sua primeira experiência efetiva de exílio ocorreu no Chile em 1971, após anos de clandestinidade no Brasil. Sua chegada ao Chile aconteceu num momento ímpar na história do país que experimentava episódios singulares com a chegada ao poder, por meio do sufrágio universal, do governo popular e socialista de Salvador Allende, em 1970.

Além da promoção de diversas reformas sociais, o Chile tornava-se inevitavelmente o abrigo de centenas de exilados dos países nos quais regimes autoritários haviam sido instaurados. O próprio Betinho, em sua chegada, foi auxiliado por José Serra, ex-presidente da UNE, que já vivia no Chile há alguns anos, oferecendo-lhe abrigo nos primeiros meses.

Ao chegar ao Chile, Betinho recuperou sua verdadeira identidade, seu contato com uma série de ex-companheiros e o simples e indescritível prazer da liberdade, 
negados na experiência da clandestinidade. Retomou também ao exercício de sua profissão e sua produção intelectual, passando a trabalhar como colaborador político de um dos assessores do presidente Allende, cargo em que substituiria ninguém menos que Darcy Ribeiro ${ }^{7}$ que estava de saída para trabalhar no governo peruano (RODRIGUES, 2007, p. 129).

Sua experiência de exílio no Chile vai muito além da retomada de sua identidade e do reencontro com a liberdade. $\mathrm{O}$ momento e as condições políticas que Betinho encontrou no Chile fizeram-no repensar toda sua trajetória e inauguraram um momento no qual nasceram novas formas de compreender sua luta. Como veremos adiante, a experiência no Chile vai constituir o antes e depois da sua vida como militante.

No entanto, o exílio chileno duraria apenas dois anos. Com o golpe militar de 11 de setembro de 1973, que derrubou o governo de Allende, instaurando uma ditadura também no Chile, Betinho, os exilados brasileiros e todos os apoiadores do presidente Allende estavam em perigo. Aqueles que conseguiram escapar da prisão e da tortura se ausentavam do país.

Inicia-se, neste momento, uma nova tentativa de fuga para Betinho que, em menos de 10 anos, experimentou diretamente o segundo golpe militar que interrompeu outra experiência histórica de governos dispostos a realizarem ações progressistas na sociedade.

O primeiro abrigo foi na embaixada do Panamá, onde ele e Maria, sua companheira, estavam em companhia de duas centenas de exilados numa pequena casa em que funcionava a representação diplomática panamenha. Após alguns meses de indefinição, Betinho conseguiu ir ao Panamá e de lá para o Canadá,

\footnotetext{
7 Darcy Ribeiro (1922-1997), antropólogo, escritor, político e educador. Mineiro de Montes Claros, formou-se na Escola de Sociologia e Política de São Paulo. Trabalhou e fez estudos com tribos indígenas do Pantanal. Escreveu várias publicações ressaltando o caráter singular e as potencialidades da civilização brasileira. Foi ministro da casa civil no governo Jango, com o golpe militar de 1964 assim como Betinho esteve exilado em diferentes países. Após a redemocratização elegeu-se vice governador do estado do Rio de Janeiro, onde também foi secretário de educação e cultura, responsável pela criação dos CIEPs, escolas de horário integral no estado do Rio de Janeiro. Foi também senador e um intelectual da educação brasileira, da qual a legislação específica leva seu nome (ver FERNANDES, 2011).
} 
onde, com o apoio de brasileiros que viviam naquele país, se estabeleceu já em 1974.

Alguns meses depois, Betinho conseguiu uma bolsa para viver e estudar na York University, nos Estados Unidos, onde permaneceu por três anos e meio, passando também alguns meses do ano de 1977 na Escócia. O último país onde Betinho vivenciou o exílio foi o México, onde recebeu o convite para trabalhar como professor da Universidade Autônoma do México.

O período no exílio significou para Betinho, fundamentalmente, a oportunidade de conhecer e identificar novas possibilidades de experiências políticas. De um contexto maniqueísta e limitado de visão política em que a tomada do Estado era percebida como forma hegemônica de mudança, as experiências do exílio levaram Betinho a conhecer a força e a importância das ações individuais, grupais e comunais na construção de uma sociedade que valorizasse e aprofundasse os fundamentos da democracia. Estes foram alguns fatores e aspectos que Betinho trouxe da experiência do exílio.

Essas experiências e aprendizados constituem os contornos fundamentais de uma nova postura que cresceu em Betinho, o engajamento pela edificação das lutas ao nível da sociedade. Essa postura materializou-se, posteriormente, no seu retorno ao Brasil na fundação do IBASE e na Campanha contra a fome. Mais que isso, foi a grande causa da vida de Betinho até sua morte. Esse realinhamento ético e político será especificado nos capítulos seguintes deste trabalho.

Em 1979, com o anúncio da Lei da Anistia, Betinho retorna ao Brasil como uma das figuras mais conhecidas e célebres do país. Imortalizado pela música de Aldir Blanc e João Bosco ${ }^{8}$, que mencionava a celebração da "volta do irmão do Henfil”, Betinho torna-se, a partir deste momento, uma das figuras públicas mais conhecidas do Brasil.

Uma de suas primeiras iniciativas foi - diferente de boa parte dos exilados, que buscaram a vida político-partidária como área de atuação - a criação de uma instituição que se voltasse para a organização do uso e difusão do conhecimento e

\footnotetext{
8 "O bêbado e a equilibrista". Composição de João Bosco e Aldir Blanc e interpretado por Elis Regina.
} 
informação à serviço da sociedade com o intuito de combater a exclusão e tornar a sociedade mais democrática (GONTIJO, 1988, p.160).

Essa instituição é o Instituto Brasileiro de Análises Sociais e Econômicas (IBASE), fundado em 1981. Essas instituições com atuação na sociedade formariam um campo em favor das ONGs, universo no qual Betinho e o IBASE tiveram papeis significativos para sua constituição e afirmação. Betinho constitui, pode-se dizer, um dos personagens que mais contribuiu, através de suas ações, para a expansão e popularização das chamadas Organizações Não Governamentais (ONGs) (LIMA NETO, 2013).

Os passos da trajetória de Betinho, desde sua origem na militância católica, como seu posterior rompimento com a igreja para seguir um caminho de ação política secular, traduziam em dinâmica individual o caminho percorrido na formação das ONGs no Brasil, que possuía uma trajetória semelhante (LIMA NETO, 2013, p. 113 e 128).

\begin{abstract}
A trajetória de Betinho representa, portanto, um microcosmo bastante representativo do que foi o processo de formação do campo das ONGs no Brasil. Seu percurso individual encontra forte correspondência com o âmbito mais abrangente de transformação dos valores sociais que conferiam sentido à noção de ONG (LIMA NETO, 2013, p. 113).
\end{abstract}

No entanto, a grande realização que conferiu maior notoriedade a Betinho foi a Campanha da Ação da Cidadania Contra a Fome, a Miséria e Pela Vida, organizada inicialmente como decorrência das lutas desenvolvidas pelo Movimento pela Ética na Política, que após triunfar na campanha pelo impeachment do presidente Fernando Collor, decidiu continuar a mobilização popular. Baseada em estudos desenvolvidos pelo IPEA $^{9}$, que à época mostravam que mais de 30 milhões de pessoas no Brasil se encontravam abaixo da linha da

\footnotetext{
${ }^{9}$ Criado na década de 1950, o IPEA (Instituto de Pesquisa Econômica Aplicada) é um órgão vinculado ao governo que produz pesquisas, projetos e estudos buscando oferecer subsídios ao governo na produção, análise e difusão com vistas ao planejamento de políticas públicas. Em 1992, o IPEA publica, sob a coordenação de Ana Maria Peliano, o "Mapa da fome: subsídios à formulação de uma política de segurança alimentar" que revelou o quadro da questão alimentar e de indigência no Brasil, que indicava na época que, 32 milhões de pessoas encontravam-se abaixo da linha da pobreza no Brasil.
} 
pobreza, buscou desenvolver uma campanha nacional que denunciasse e mobilizasse a sociedade para enfrentar tal problema.

Betinho tornou-se a figura mais proeminente deste movimento que, lançado em março de 1993, alcançou projeção nacional. O movimento buscava estimular a solidariedade e a intolerância ao estado de exclusão de cerca de 1/6 da população que, como veremos adiante, começava com a doação de alimentos como ação emergencial, mas buscava também chamar a atenção da população para a discussão sobre a natureza e legitimidade de uma sociedade que excluía a maioria das pessoas.

A projeção que alcançou o movimento é inédita. Em 1993, parte significativa da sociedade engajou-se na campanha, chamando atenção o grande número de pessoas que não possuíam experiências de ação e engajamento político anteriores. Pesquisa realizada pelo IBOPE à época em várias cidades brasileiras revelou que $68 \%$ dos entrevistados afirmavam conhecer a campanha e $32 \%$ deles já haviam contribuído de alguma forma com ela.

Betinho, após a Campanha, tornou-se figura nacionalmente conhecida pela causa da solidariedade, uma espécie de "Gandhi" brasileiro, imagem que ficou no imaginário também por seus infortúnios pessoais, pelas doenças, pela fragilidade física, etc.

Mesmo com o episódio do jogo do bicho, no qual foi revelado que Betinho teria aceitado doação de bicheiros para salvar a $\operatorname{ABIA}^{10}$ (Associação Brasileira Interdisciplinar da AIDS), que passava por severa crise financeira, fato que durante algum tempo comprometeu sua imagem e foi, como o próprio Betinho chegou a afirmar, um grande baque, a imagem que ficou de sua figura, no entanto, transcende a este episódio.

\footnotetext{
${ }^{10}$ ABIA: Fundada em 1987, sediada no Rio de Janeiro, tinha como objetivos a mobilização e esclarecimento da sociedade sobre a epidemia de Aids. Formada por profissionais de diversas áreas, tinha como desafios atuar no enfrentamento da Aids a partir da perspectiva dos direitos humanos.
} 
Em agosto de 1997, vitimado pela Aids, que já tinha levado seus dois irmãos, o músico Chico Mario e o cartunista Henfil, Betinho deixou esta vida e, também, muitas lições. Algumas delas serão resgatadas neste trabalho.

A figura de Betinho, até hoje, em grande medida, é lembrada pela experiência da Campanha contra a fome. No entanto, ela era expressão de uma luta que continha propósitos mais profundos e revolucionários. Carregava em seu bojo a compreensão da ação emergencial e estrutural aglutinadas num mesmo processo como faces de uma mesma moeda. Ao longo deste trabalho, buscaremos investigar estas características da campanha, sobretudo no segundo e terceiro capítulos.

Nas seções seguintes deste capítulo, buscar-se-á organizar, em perspectiva, a evolução das mudanças das ideias de Betinho e como a experiência do exílio foi fundamental para a descoberta de novos valores que, mais tarde, seriam materializados na campanha contra a fome.

\subsection{A experiência do exílio: o momento determinante na vida de Betinho}

\subsubsection{Mudar o Estado para mudar a sociedade: lutas e ações políticas de Betinho anteriores ao exílio}

Conforme visto anteriormente, a trajetória de Betinho experimentou muitas e profundas mudanças de ordem pessoal, intelectual, política e até mesmo geográfica. Uma dessas experiências fundamentais que revela uma espécie de antes e depois em sua biografia encontra-se na dimensão da revisão dos valores e das formas de ação política.

Suas experiências políticas iniciaram-se ainda em meados da década de 1950 na Ação Católica (JEC depois JUC). Betinho, influenciado pelos setores mais 
progressistas da igreja, levou cada vez mais sua experiência de ação no movimento estudantil para uma visão de mundo que condenava e incompatibilizava a postura cristã com as injustiças no mundo. E a forma de posicionar-se contra essas injustiças estava em defender uma proposta anticapitalista.

Esta luta anticapitalista na passagem da década de 1950 para 1960 esteve compreendida por uma proposição não apenas de simpatia ao socialismo, mas também pela identificação do Estado como o agente fundamental que poderia processar as mudanças necessárias.

Ainda na experiência da JUC, Betinho e parte daquela geração que emergiu da juventude católica aderiram a uma postura que, em sua visão, condenava as incoerências da sociedade capitalista. Ainda que não houvesse consenso quanto à classificação ou nomenclatura da ideologia, o conteúdo defendido por parte expressiva da JUC mineira carregava uma visão de mundo com tais bandeiras e ideais socialistas (SOUZA, 1978, p. 73).

Nesse sentido, a criação da Ação Popular (AP), em 1962, representou um momento de afirmação e cristalização não apenas de Betinho, mas pelo estímulo de lutas nos contextos nacional e internacional. Com a criação da AP, o desenvolvimento de uma proposta de ruptura pretendida por alguns setores da JUC ficava mais propício, pois já estava fora dos marcos institucionais da igreja.

Novamente, o alinhamento da AP reitera uma visão presente ainda em tempos de JUC, a visão do Estado como principal esfera para a promoção de mudanças na estrutura social. Até o momento, ele era visto como o meio mais eficaz de realizar a empreitada de mudanças para o Brasil.

Nesse sentido, a AP ganha cada vez mais espaço no cenário político nacional com um discurso semelhante ao do Partido Comunista sem, no entanto, ter de carregar o peso do nome ou estigma partidário, além de ter seu discurso melhor adaptado ao contexto brasileiro (GONTIJO, 1988, p.65; SOUZA, 1978, p. 75 e 76). 
A AP coloca-se não apenas como uma organização fundamental no início da década de 1960, mas estrutura o eixo de suas ideias de transformação por meio da mudança do Estado com uma organização e uma agenda semelhante a um partido. O próprio Betinho percebeu posteriormente esse alinhamento, essa postura sua por meio da AP:

\begin{abstract}
A AP nasceu como uma organização de massa avançada, como um movimento. Foi este seu caráter que gerou sua força, sua sensibilidade e capacidade de expansão (...). Acho que nós vivemos um movimento com direção para um partido de massa. Isso ficou claro em 1964, e se não houvesse 64 a AP poderia ter vindo a ser um partido de massas, ainda que limitado. Mas seria um partido político, com quadros, com militantes e com um apoio popular (SOUZA, 1978, p. 76).
\end{abstract}

A ocorrência do golpe militar em 1964, além de interromper o desenvolvimento de muitas lutas ao nível da sociedade, deteve o ímpeto das formas de avanços, tanto no Estado, como na sociedade, ou no movimento estudantil.

Para Betinho, o golpe implicou inicialmente sua ida ao Uruguai em junho de 1964, junto a outros políticos e militantes para tentar organizar a resistência ao golpe. No ano seguinte, ele retornou ao Brasil na condição de clandestino. Uma das principais motivações para a volta de Betinho como de outros foi a crença na possibilidade de montar uma resistência capaz de derrotar a ditadura civil-militar.

No bojo desta crença, tem-se ainda uma clara observação sobre que, para se alcançar a efetiva mudança, a tomada do Estado constituía elemento central das transformações almejadas por Betinho e outras importantes organizações da esquerda brasileira.

Nesse período, a AP inicia uma guinada que, posteriormente, seria fundamental para a trajetória de Betinho, inclinando-se para uma leitura cada vez mais estreita do marxismo e dela para o maoísmo, como um tipo cada vez mais dogmático de ação e compreensão do mundo.

As escolhas e diretrizes encaminhadas pela direção da AP iniciaram um processo contínuo de discordância crescente com Betinho. No entanto, em fins da década de 1960, na perspectiva de Betinho, ainda se encontrava a crença de que a 
clandestinidade teria ainda algum tipo de condição de fazer frente à ditadura, entendimento que, como veremos adiante, será modificado.

O episódio mais característico deste momento de Betinho e da AP deu-se, inspirado nas orientações maoístas tomadas pela AP, quando Betinho foi levado a um processo de proletarização, no qual militou e viveu diretamente a experiência de um operário, trabalhando numa fábrica no ABC paulista (GONTIJO, 1988, p102 e 103; NAKANO, 2000, p.326).

Neste período, a questão que se coloca para Betinho, que começa a fazer um exercício de questionamento de sua prática, encontrava-se no fato de que a organização que ajudara a criar, a AP, seguia um caminho cada vez mais distante de sua fundação e da realidade daquele momento. Betinho observa assim este momento:

\begin{abstract}
Dizem-me que sou um pequeno burguês, que nunca deixei de ser. Então, porque sou pequeno burguês, tenho que passar por um processo de proletarização, o que significa purgar todas as vestes de pequeno burguês e tornar-me um operário. Se eu cumprisse isso teria condições de ser um militante revolucionário, um verdadeiro marxista-leninistamaioísta, e portanto pronto para me incorporar na nova organização, no novo partido do operariado que tinha surgido no Brasil (a AP, grifo meu) (SOUZA, 1978, p. 82).
\end{abstract}

Os questionamentos de Betinho começam a aprofundar-se neste momento, como o sentido e os caminhos de sua luta e a viabilidade de suas escolhas. A luta contra um Estado autoritário e equipado com todo aparato repressivo levou Betinho a questionar profundamente a escolha realizada não apenas pela AP, mas também por outras importantes organizações de esquerda - como a ALN de Marighella, o MR8 de Lamarca - que, naquele momento, faziam oposição ao regime militar clandestinamente, abraçando uma luta cujas condições objetivas se mostravam improváveis de alcançar sucesso.

Os desencontros com a direção da AP, somado ao eminente perigo representado pelas constantes prisões aos militantes do ABC paulista, onde funcionava seu aparelho, fazem Betinho tomar a decisão de deixar o Brasil. Assim, ele narrou seu pensamento e sua decisão: 
Outra tomada de consciência muito grande foi a de que nós não éramos quase nada, ou praticamente nada, que nós não éramos um partido, que não éramos um partido da classe operária, que não tínhamos condições de sobrevivência, que nessa altura não só a minha vida, mas em conjunto era uma situação de suicídio. E isso não era política! Foi então que tomei a decisão, com alguns poucos amigos de sair, e de sair de qualquer jeito. Apesar de que alguns não concordaram, a maioria que estava vivendo a mesma circunstância concordou e, inclusive facilitou a minha saída. É assim que em novembro de 1971 prevendo todas as quedas que sucessivamente iriam ocorrer, saio e vou fazer uma longa viagem. Desta vez para o Chile (SOUZA, 1978, p. 90).

Betinho parte, então, para o exílio, decisão que será fundamental para a constituição de uma nova forma de conceber sua ação política não apenas pregressa, mas que, na perspectiva deste trabalho, inaugura uma nova forma de lutar pelas mesmas causas que marcarão todas as iniciativas posteriores na vida de Betinho, inclusive a última e mais famosa, a Campanha da Ação da Cidadania Contra a Fome, a Miséria e Pela Vida.

\subsubsection{A experiência do Chile e a descoberta de outra forma de ação política}

A saída do Brasil e a chegada ao Chile, para além da questão política, representou, para a experiência pessoal e existencial de Betinho, a possibilidade de um renascimento, após anos de clandestinidade, de modo a viver como cidadão. Assim, Betinho narra essa experiência de reavivamento:

Volto a ser eu mesmo e durante uns dez dias fico igual ao cara que passa numa mina sem ver luz do sol, que não respira o ar puro e de repente se vê diante de um lago iluminado, com flores, água fresca. Durante dez dias fiquei embriagado. Sentava nas praças, embriagado com o clima, com o povo, andava, sentava nos bares, olhava aquela gente, e era como se eu dissesse assim: "agora sou gente também, né, não tem esquadrão da morte, nem cenimar". Não tem que entrar ou sair do ônibus e olhar para ver se estava sendo perseguido" (GONTIJO, 1988, p.110). 
No Chile, Betinho retoma sua carreira profissional, trabalhando diretamente com um dos assessores do presidente Allende, posto deixado por Darcy Ribeiro que havia ido ao Peru. Deixar o Brasil na condição de clandestino e encontrar no Chile o retorno à atividade profissional, ao livre pensamento, à possibilidade de ser ele mesmo, foi, naquele momento, uma experiência altamente prazerosa. Betinho classifica como "surreal" a possibilidade de, em seu trabalho, constatar que algumas das ideias desenvolvidas por ele se tornariam reais no governo Allende (NAKANO, 2000, p.327).

A chegada ao Chile representou, na trajetória de Betinho, a realização de um processo de revisão de sua trajetória. Neste momento, junto ao impacto positivo do reencontro com a experiência democrática no Chile, Betinho permitiu abrir-se ao exercício de reflexão sobre as formas de ação política vivenciadas por ele até então.

Nesse reexame, a insuficiência de uma clareza analítica entre o que se almejava e as condições reais que se apresentavam no contexto brasileiro constitui uma das maiores críticas realizadas aos opositores do regime militar - que acreditavam ser possível derrubar o governo com algumas centenas de militantes -, às organizações de esquerda, inclusive à $\mathrm{AP}$ e a si próprio.

Esse momento de reflexão e autocrítica é possibilitado, sobretudo, pelo contraste observado por Betinho ao chegar ao Chile, onde as formas de ação política se davam numa dimensão maior que a experiência dos anos que antecederam o golpe militar no Brasil:

A partir daí, de 71 até o golpe, foi um período de descobrir o que era a política numa situação extrema, porque o Chile era inegavelmente o país de maior politização e mobilização política da América Latina, senão do mundo, tirando certos países da Ásia e mesmo da Europa. Foi um curso intensivo de ciências políticas em dois anos. Aí você vai descobrir o que é massa, o que é luta de classes, o que é partido. Ai você vai descobrir o que é liderança, e o que é não ser liderança, como é que se desenvolve o nível político, qual a relação entre economia e política. Ai você sai de uma situação sem política, ou apolítica, para uma situação de Política com P maiúsculo, a política em dimensões de massa (SOUZA, 1978, p.95). 
Em outro momento, Betinho refere-se a este mesmo contexto decisivo em sua experiência:

\begin{abstract}
Como disse, o Chile foi um curso de política, porque aqui no Brasil a gente reunia 30 pessoas e dizíamos: 'fizemos um ato de massas'. No Chile, quando se fazia uma manifestação de 600 mil, se dizia que foi um fracasso. Aí você começa a rever todas as categorias, como: o que é massa? Nas manifestações, você via todas as classes organizadas e em lugares separados, uma coisa fantástica, os professores, os metalúrgicos, os mineiros, todos com suas bandeiras. Era uma aula de luta de classes ao vivo (SOUZA, 1996, p. 98 b).
\end{abstract}

A chegada ao Chile só confirmou as desconfianças suscitadas por Betinho nos últimos anos de clandestinidade no Brasil. Uma espécie de "nova certeza" cada vez mais se delineava na concepção de Betinho, a de que não seria suficiente apenas a "boa vontade" de uma esquerda comprometida em tomar o Estado, mas conhecer sua própria dimensão e dialogar com a sociedade constituíam elementos fundamentais e imprescindíveis. Betinho percebeu o quanto era necessário repensar sua ação política anterior.

Uma situação revolucionária não poderia ser desenvolvida ou almejada olhando-se apenas para o Estado. Para que não fosse uma criação artificial, seria imprescindível a força e participação da sociedade, tal qual a presenciada por Betinho no Chile.

Uma situação revolucionária não poderia ser desenvolvida ou almejada olhando-se apenas para o Estado. Ela não adviria de uma criação artificial, mas necessitava de uma força que só a sociedade tinha, tal qual aquela que Betinho presenciara em seu exílio no Chile.

Betinho conclui, após a chegada ao Chile, o que ele denomina como seu processo de "revisão e autocrítica", no qual se viu assombrado com a dimensão, com a participação da sociedade no processo democrático daquele país. Ali, sim, era possível afirmar que milhões de pessoas entravam na história e faziam história. Essa experiência obrigou-o a olhar para sua ação anterior, ainda no espaço brasileiro, e a problematizar a postura das organizações de esquerda que reivindicavam a luta armada, a AP e a ele mesmo (SOUZA, 1978, p.95). 
O conjunto das reflexões desenvolvidas a partir do contato com a experiência chilena levou Betinho a perceber que, mais importante que lutar pela tomada do Estado, ou conquistar o Estado, seria necessário conquistar a sociedade.

Os movimentos de mudança não viriam da aplicação das cartilhas e teorias desvinculadas da realidade, como a própria AP e Betinho acabaram por realizar em fins da década de 1960. A mudança/ruptura necessitava vir da realidade concreta, isto é, vir da sociedade em um movimento vivo das massas.

O efeito pedagógico da experiência chilena levou a trajetória de Betinho a se dividir em antes e depois dela.

O Chile foi o contraponto dos anos anteriores. Ele me permitiu completar a crítica à Ação Popular e colocar um fim naquela relação esquizofrênica com o mundo... Entendia cada vez mais que a política é um processo e não uma lógica, e que participam deste processo diferentes pessoas, movimentos, grupos, atores sociais, de comum acordo ou não (SOUZA apud NAKANO, 2000, p. 328).

A partir deste momento, o Estado deixa de ser uma categoria central de análise para Betinho. Em seu lugar, passa a ter cada vez mais importância a percepção de que a luta que desenvolvia até então estava muito mais próxima ao que ele mesmo classificou de "sentido missionário", na qual a leitura marxista dada de forma estreita o teria levado a lutar pela emergência de uma situação, que no caso brasileiro, não existia.

Nem ele, nem ninguém seriam capazes de ser o "senhor do povo", da massa. Pois, a própria sociedade, em qualquer contexto - como o que ele vira no Chile se fazia aparecer. Ali sim, podia-se falar de um movimento, porque haveria correspondência com a realidade. Enfim, sem ficar insensível a tais realidades, mas sem a pretensão de criá-las. Essa foi a lição que o Chile deu a Betinho (SOUZA, 1978, p.102).

A lição dada pela experiência chilena foi apropriada e encampada por Betinho. Novos valores foram incorporados à sua forma de pensamento enquanto outros ficaram para trás. O dogmatismo e a visão estreita e monocromática da realidade dão lugar ao valor da democracia como fundamento principal para as mudanças. 
Na relação Estado x sociedade, a sociedade adquire cada vez mais importância para pensar o projeto de edificação de um novo país. Tais concepções se cristalizam continuamente na experiência de Betinho durante todo o exílio. Mesmo o golpe militar no Chile, em 1973, que o obriga novamente a partir para outros países, já não é capaz de deter o aprendizado dos últimos dois anos de exílio.

Esta lição trazida desde o exílio no Chile constitui a base de todo movimento de revisão realizado por Betinho, na qual a mudança do Estado só se torna útil se for construída através da participação da sociedade.

O conjunto de suas mudanças é resumido por Betinho da seguinte maneira:

\begin{abstract}
No que diz respeito ao meu engajamento na esquerda, evolui de uma visão estreita e autoritária em seus métodos, muito dogmática, em direção a uma outra visão da política, afastando-me da esquerda clássica. A questão da democracia se tornou, cada vez mais, a preocupação central. Matizei e tornei relativo o papel dos partidos. Reforcei a importância da ética como fator de construção da política. Em meu espírito, apareceram outros princípios que qualifico de democráticos. Eles existem na realidade, mas não os encontro na teoria. Vejo a democracia como um processo infinito, interminável, mas concreto (SOUZA apud NAKANO, 2000, p. 331).
\end{abstract}

Mais do que a transição de formas de poder, orientadas verticalmente, Betinho cristaliza a percepção de que o eixo central das mudanças, para que sejam efetivas, não podem se basear somente na discussão da mudança do Estado. Elas precisam ser orientadas por mudanças que comecem nas bases, da sociedade para o Estado, não pelo caminho inverso.

Os novos princípios democráticos que passam a orientar a conduta de Betinho serão mais bem desenvolvidos na seção seguinte, onde seu conceito de democracia será objeto de análise.

No entanto, no que se refere aos marcos deste trabalho - que busca, na trajetória decorrida anteriormente por Betinho, outras possibilidades de leituras para entender um dos projetos pelo qual ficou nacionalmente conhecido, a Campanha contra a fome - a experiência do exílio no Chile, pode-se dizer, constitui o divisor 
de águas, quando passa a existir em Betinho a concepção de uma nova forma de ação política.

Sem a experiência chilena, arriscamo-nos a afirmar, a Campanha da Ação da Cidadania talvez nunca tivesse existido, ou pelo menos não teria o caráter de uma ação ético-política de repúdio à existência da miséria num país rico. Essa concepção fortemente presente na campanha, logicamente transcende em muito a pura e simples doação de alimentos.

A partir da experiência chilena, Betinho repensa suas orientações, que ao nível das teorias se transferem de uma visão estritamente classista, das classes como atores principais do processo histórico, para a história numa outra perspectiva. Em suas palavras, a história passa a ser percebida como: "ação e contradição de milhares de ações, coletivas ou individuais" (SOUZA, 1996, p. 145 b).

A análise posterior que o próprio Betinho faz sobre a edificação de novos valores em sua trajetória é compreendida da seguinte forma:

\begin{abstract}
Acho que nesse caso houve uma evolução do meu pensamento do ponto de vista teórico e do ponto de vista prático. Do ponto de vista teórico eu descubro a democracia como questão central, como referência básica. E na prática eu descubro a importância e o valor do cidadão, do indivíduo. Fiz uma descoberta óbvia: a sociedade é composta de indivíduos e eles atuam de acordo com seus ideais e suas aspirações, recebem influência (SOUZA, 1996, p.145 b).
\end{abstract}

Essa abertura, essa permissão de olhar o mundo e suas contradições a partir de outros enfoques além das classes, sem negá-las, possibilita a Betinho expandir sua compreensão política, perceber que a ação política se faz não apenas na política partidária ou no Estado, mas na sociedade, na mobilização das pessoas.

No entanto, o conjunto das observações que levam Betinho a repensar suas ações a partir do exílio no Chile, longe de representarem um abandono de suas ideias, expressa seu compromisso com a luta contrária à exclusão e às desigualdades numa outra arena de lutas. No exílio, Betinho compreende que não se deveria atropelar a história ou fabricá-la, como pensava ele, a AP e boa parte dos movimentos de esquerda no Brasil que encamparam a luta contra a ditadura a 
partir da estratégica da luta armada, o que levava a um confronto direto e desproporcional com o Estado autoritário nas décadas de 1960 e 70.

Ainda no exílio, Betinho observa como a sua passagem pelo Chile foi um momento importante de reflexão sobre a sua experiência:

Enfim, o Chile vai ser outro momento elevado de compreensão do que é política. Do que é processo revolucionário. É uma oportunidade mais profunda para se refletir o que tem sido nossa experiência no Brasil e sobre como a gente vê e continua a analisar política no Brasil. (SOUZA, 1978, p. 96).

Essa experiência fundamental o permite não apenas refletir sobre as incorreções do passado, mas projetar uma nova forma de ação política que fizesse do passado um instrumento pedagógico.

A despeito do conjunto das redefinições no pensamento de Betinho, como as elencadas acima, permaneceu sempre em sua trajetória, desde a juventude na JEC/JUC até o fim de sua vida, o compromisso com a modificação da excludente e desigual - estrutura social e econômica brasileira.

As mudanças aparecem na forma e no caminho de reivindicar tais mudanças. $\mathrm{O}$ sentido e objetivo de tais mudanças permanecem como um valor, um compromisso ético-político que Betinho deixou para a sociedade como um legado.

A seguir buscaremos analisar, mais cuidadosamente, os novos ideais que iluminaram o pensamento de Betinho a partir do contato com o exílio. Sobretudo, seu conceito de democracia que passou a orientar suas ações e juízos.

\subsection{Betinho e sua concepção de democracia}

Na seção anterior, concentramo-nos em avaliar como, no bojo da trajetória de Betinho, a experiência da clandestinidade e do exílio, sobretudo o exílio no Chile, 
foram fundamentais para trazer à tona uma reavaliação de sua forma de pensamento.

Os princípios de mudanças que estavam concentrados na tomada do Estado foram repensados de forma que, para Betinho, o Estado deixou de ser o único ator histórico preponderante, aparecendo em seus horizontes analíticos outras perspectivas de luta.

O alinhamento com uma postura próxima da leitura estreita do marxismo e do maoísmo dos tempos de clandestinidade cede lugar para a compreensão do valor da democracia. Como afirmou posteriormente, do ponto de vista teórico, da evolução do tempo e de suas experiências, descobriu-se o valor central da democracia como caminho para a edificação de uma nova sociedade.

Estado, marxismo, liberalismo tornam-se noções secundárias frente à concepção de que o mais importante é o que se forja na esfera da sociedade. Somente a democracia poderia formar uma sociedade que suprimisse as históricas injustiças. Pode-se dizer que, a partir da experiência do exílio, a construção da democracia passa a ser o projeto de vida de Betinho.

Os itinerários traçados por Betinho levaram-no do Estado à sociedade, uma sociedade construída pela democracia cuja necessidade primeira seria a cidadania, isto é, a participação popular efetiva. Essa caminhada é fundamental para se compreender os passos traçados por Betinho, posteriormente, a partir de seu retorno do exílio e, sobretudo, na campanha da Ação da Cidadania. A democracia surge como um novo farol que ilumina sua trajetória de lutas:

Se nos anos 1970 e 80, a preocupação do Betinho sociólogo era o Estado, nos aos 90, ainda antes da Campanha contra a fome, o foco dele se direcionava para a cidadania, à qual o Estado para ele, deveria se subordinar. Na visão de Betinho, democracia e cidadania 'de mãos dadas', seriam incompatíveis com o capitalismo e com as experiências socialistas totalitárias (PANDOLFI; GAZIR; CORREA, 2012, p.175).

Este termo (democracia) no entanto, se torna complexo de avaliar por sua característica polissêmica. Pensada desde a Grécia antiga, a democracia tem 
iluminado as noções e ideais mais distintos. Em seu nome praticaram-se as mais diversas ações, revoluções, contrarrevoluções etc.

Nesse sentido, a despeito da polissemia do termo "democracia" e de sua larga problematização no pensamento social, tomamos como base a ideia de democracia reivindicada por Betinho.

É salutar lembrar que, apesar de explicitar seu entendimento sobre seu ideal de democracia em diversas publicações - como veremos a seguir -, por não se encontrar sob as regras da escrita e mesmo do ambiente acadêmico, além de dirigir seu discurso a um público amplo, as caracterizações de Betinho por vezes não possuem o rigor acadêmico ou a preocupação em atender aos requisitos inerentes à problematização científica de um determinado conceito.

Com isto, é possível encontrar, por vezes, propostas ou entendimentos expressos sem o que classificaríamos de rigor científico. Feita a ressalva a este respeito, como o objetivo deste trabalho está em compreender a experiência da Campanha da Ação da Cidadania à luz da trajetória de Betinho, tomamos como base a ideia de democracia pensada por ele.

Elegendo a democracia como concepção que passou a iluminar sua visão de mundo, Betinho procurou esclarecer e caracterizar em seus pormenores o que entendia por democracia, ou melhor, a que tipo de democracia ele se referia quando a defendia.

Primeiramente, o conceito de democracia defendido por Betinho caracteriza-se por sua amplitude e distância, quase utópica, que, no entanto, pode ser construído a cada dia em todas as esferas, desde as mais simples. Combinando seus aspectos constitutivos, ela seria responsável por revoluções. Sua concepção de democracia, inicialmente, contempla cinco dimensões fundamentais que orientam sua visão:

No meu entender, são cinco os princípios definidores de uma relação democrática: liberdade, igualdade, participação, diversidade e solidariedade. Não existe democracia sem liberdade, igualdade, participação, solidariedade e diversidade, que é reconhecer e admitir as diferenças, saber que se pode ser igual ao outro, mas diferente (SOUZA, 1994, p. 20 f). 
As cinco dimensões constitutivas da democracia fundam uma ética altamente revolucionária se se considera que, para sua efetivação, a sociedade teria de refundar suas bases. Sobre estas dimensões, Betinho observa ainda:

Cada um separado, quase daria para transformar o mundo. Imagine todos eles juntos. Juntar igualdade com diversidade e liberdade, temperar com solidariedade, conseguida pela participação, este é o grande desafio da democracia: a simultaneidade na realização concreta dos cinco princípios, meta sempre irrealizável e, ao mesmo tempo, possível de ser tentada a cada passo, em cada relação, em cada aspecto da vida (SOUZA, 1996, p. 66 a).

Seu conceito de democracia caracteriza-se por aglutinar de forma harmônica as questões emergenciais e estruturais, o agora e o futuro, o simples e o complexo, como faces de uma mesma moeda, como elementos indissociáveis. Neste aspecto residia não apenas sua natureza, mas também sua identidade, associada a toda trajetória futura de Betinho. Pensar o futuro pressupõe necessariamente pensar o agora, pois não há como falar do futuro sem agir no presente (SOUZA, 1991, p.12).

A Campanha da Ação da Cidadania foi compreendida por muitos como uma simples ação assistencialista. Esta leitura superficial não levava em conta que tal Campanha possuía uma ligação estreita com a concepção de democracia desenvolvida por Betinho desde a década 1970. O pensar uma nova sociedade e a modificação da estrutura social ligava-se diretamente à transformação do agora.

É na articulação entre realidade e utopia, do visível e do invisível, que reside um aspecto singular de seu conceito de democracia.

A democracia é o igual e o diverso. O encontro de liberdades. A convergência da pessoa e da comunidade. Da sociedade civil e do Estado (Administração do bem público). A democracia é o atendimento do básico e do transcendental . Do pão e da liberdade. Do finito e do infinito. Do eu e do nós. É a afirmação da consciência, no mundo de sua falsificação em relações coisificada. Democracia é obra sem limites e portanto, inacabável, Mas democracia é exatamente aquilo que fizermos dela e por isso é fundamental inventá-la a todos os níveis e a cada momento (SOUZA, 1991, p.12). 
O processo de transformação proposto por Betinho que articula tais dimensões busca superar também o histórico discurso de mudança, em que os resultados efetivos destas são colhidos apenas num futuro longínquo, a longo prazo; em que as promessas de transferência dos benefícios da riqueza e dos aspectos positivos são projetadas para um futuro incompreensível e impalpável, ou seja, a perder de vista.

Iniciando pelas questões urgentes, locais, do presente, a democracia constitui-se num caminho que conduz tais lutas às questões estruturais, do futuro e gerais. Esta democracia tem, necessariamente, uma trajetória ascendente - da sociedade para o Estado - e não o contrário. Um conceito genuíno e fundamental na democracia para Betinho está na participação ativa e contínua, desde as questões do dia-a-dia, às questões estruturais:

\begin{abstract}
A democracia não se refere somente à ordem do poder público, do Estado, mas deve existir em todas as relações sociais, econômicas, políticas e culturais. Começa na relação interindividual, passa pela família, a empresa, as igrejas, as instituições da sociedade civil e culmina no Estado. Uma sociedade democrática é aquela que vai conseguindo democratizar todas as suas instituições e práticas. É uma sociedade perpassada pelos princípios, construídas por eles, de forma consciente, voluntária e livre. É o reconhecimento da humanidade de todos por todas as pessoas. A democracia não nasce das máquinas, mas das pessoas. É obra da consciência humana, a mais sofisticada das tecnologias (SOUZA, 1996, p. 68 a).
\end{abstract}

Seu ideal de democracia necessita inexoravelmente associar-se à experiência da cidadania, que se inicia na participação do cidadão. Esta participação de forma alguma se confunde ou se reduz ao sufrágio universal (SOUZA, 1996, p. 67 a). A participação do cidadão precisa ser presente em todo tempo, em todos os aspectos da vida social. Este nível de participação cidadã, da vivência cotidiana da cidadania constitui a base da democracia pensada por Betinho.

Nesse sentido, Betinho chama a atenção para o que classifica de uma espécie de espelho invertido, que leva o senso comum a pensar, no caso brasileiro, que as pessoas, os cidadãos, ou grupos teriam suas necessidades fundamentais supridas pelo Estado, imagem que foi tão presente, que quase sufocava a própria sociedade. Betinho observa então que, apesar deste histórico, é o Estado que depende do 
cidadão, da sociedade, para se impor. Sem os cidadãos, sem a sociedade, o Estado não seria nada (SOUZA, 1996, p.67 a).

Mais adiante, Betinho reafirma como seu conceito de cidadania passa pela construção da experiência cidadã em todas as esferas da sociedade:

\begin{abstract}
Quando o cidadão descobre que ele é o princípio do que existe e pode existir com sua participação, começa a surgir a democracia. Cidadania e democracia andam de mãos dadas e não existem separadas. Cidadania não é individualismo, mas afirmação de cada um em sua relação de solidariedade com os outros. Cidadania e democracia estão baseados em princípios éticos e tem o infinito como limite. Não existe limite para a solidariedade, a liberdade, a igualdade, participação e diversidade. A democracia é uma obra inesgotável (SOUZA, 1996, p. 67 a).
\end{abstract}

Para ser salutar, a experiência democrática necessitava ser radicalizada. E a radicalização da democracia era entendida como a contínua expansão de suas potencialidades, de suas formas de participação. Logo, a democracia nunca estaria perfeitamente completa, ela seria um contínuo e interminável processo de ampliação de direitos. E seria este inesgotável processo que construiria a força da democracia numa sociedade.

\title{
2.4. Incompatibilidade entre capitalismo e democracia
}

O conjunto de mudanças que Betinho classificou como ideais democráticos, fruto de seu processo de revisão, dá-se, podemos dizer, preservando uma coerência e compromisso com a mudança da estrutura social brasileira. Se os princípios democráticos passam a constituir o farol que ilumina suas ações, é também perceptível na trajetória de Betinho a manutenção da crítica às incoerências da sociedade capitalista, assim como a denúncia de sua insuficiência para a resolução dos problemas fundamentais da sociedade brasileira. 
Em sua visão, o caminho para alcançar a sociedade radicalmente democrática passa inexoravelmente pela superação das bases fundamentais da sociedade capitalista. Pois, para ele, a sociedade capitalista se fundaria na negação dos princípios democráticos. Logo, sua proposta de democracia aparece como preponderantemente revolucionária, pois sua proposição reivindicava outra estrutura social que revogasse os fundamentos da sociedade capitalista.

Na condição de defensor de sua proposta de democracia, Betinho manteve sua visão anticapitalista, baseada no fato de que o capitalismo era incapaz de resolver os problemas da sociedade como um todo. (SOUZA, 1987, p.13).

Aí reside a grande diferença entre a concepção de democracia de Betinho e os limites da sociedade capitalista. Betinho observava que a proposta democrática seria para todos. Ou serviria para todos ou não serviria. Um projeto de estrutura social que só englobasse alguns e excluísse outros - ou a maioria - não serviria à democracia, devendo ser repensado.

Como no caso da sociedade capitalista que, conforme observava Betinho, garantia direitos de igualdade para alguns e incluía apenas uma parcela da sociedade. Os que se encontram fora do universo produtivo do capitalismo nem sequer existem para tal projeto de sociedade.

Betinho, então, organiza o eixo fundamental de sua luta no questionamento de uma configuração de sociedade que excluía parte importante dela.

Além de não incorporar todos os setores da sociedade, na visão de Betinho, a sociedade capitalista constituía-se como nociva por tratar com desconfiança toda e qualquer proposta de inclusão completa. Betinho utiliza o exemplo dos excluídos brasileiros, que por volta de fins da década de 1980, estavam em torno de 50 milhões de pessoas não inclusas no projeto do capitalismo brasileiro:

O exemplo é real, apesar de simples. Se 50 milhões de brasileiros não estão integrados ao mercado, ao sistema produtivo do capital (ao mundo do capital), esse não é um problema do capitalismo no Brasil, simplesmente é um problema para cada um dos 50 milhões de pessoas, externo ao sistema econômico, problema social de assistentes sociais ou políticos interessados na manutenção da ordem. Por outro lado tentar incorporar esses 50 milhões na ordem do capital é provocar desordem para o capital, daí que todo discurso distributivo seja visto como subversivo, ou utópico (SOUZA, 1987, p. 13). 
A proposta de democracia de Betinho caminha no sentido inverso da proposta de sociedade capitalista, tal como ela era compreendida por Betinho. Dentre os aspectos fundamentais e os princípios gerais do capitalismo, que se concentram na sua busca pelo desenvolvimento do capital, do mercado, não necessariamente estariam incluídos o conjunto dos trabalhadores ou a sociedade; na proposta de democracia de Betinho, o desenvolvimento humano estaria em primeiro lugar:

\begin{abstract}
Propor a democracia como negação do capitalismo é propor uma sociedade igualitária e participativa, onde todos constituem o sujeito de sua própria construção como sociedade. É propor uma utopia que nunca se completa por mais que se realiza. O capital é e pretende ser tudo para o mundo do capital, enquanto a democracia é e pretende ser tudo para o mundo que surge da negação do capital (...). Porque o desenvolvimento total do capital não implica no desenvolvimento total da sociedade onde se realiza o capital. O capital se desenvolve na sociedade, mas não é o desenvolvimento do mundo, mas de si mesmo (SOUZA, 1987, p. 16 e 17).
\end{abstract}

A proposta democrática de Betinho tinha, nos marcos da sociedade capitalista, a impossibilidade concreta de sua realização devido à incompatibilidade estrutural tanto dos marcos do capitalismo, quanto de sua proposta de democracia.

Uma sociedade pensada e direcionada para a realização do bem comum, para a satisfação das necessidades humanas, sejam elas individuais ou sociais, seria inevitavelmente revolucionária no sentido de ir além das possibilidades oferecidas pelo projeto de capitalismo por aqui desenvolvido. No que diz respeito a este quesito, o conceito de democracia proposto por Betinho coloca-se como revolucionário por pensar a organização de uma estrutura social distinta, que, ao mesmo tempo, possui bases utópicas, mas possíveis de serem construídas a cada dia, a cada momento.

A crítica de Betinho à ideia do livre mercado está no fato de que ele separaria esferas indissociáveis, criando uma pretensa economia fora do aspecto ético e humano da sociedade, uma economia desvinculada e sem responsabilidade para com os diversos setores da sociedade, como se ela própria tivesse vida fora da sociedade (SOUZA, 1987, p. 97 e 98). 
A invenção desta ideia da possibilidade da economia tendo uma suposta vida à margem da sociedade, criando uma inversão de papeis, onde a criatura postula ser criadora, foi analisada há décadas no campo das Ciências Sociais, por Karl Polanyi em sua obra "A grande transformação". Nela, o autor observa o mito da economia autorregulada como uma criação historicamente datada, diferente do que postulavam seus defensores, que remeteria a uma característica da natureza humana (POLANYI, 2012).

Em sua análise, Polanyi discute a "grande transformação", que consiste na emergência de um discurso, a partir de fins do século XVIII e século seguinte, e de uma forma de pensamento trazidos por filósofos da economia liberal, como Adam Smith ${ }^{11}$, que postulavam a existência de um mercado autorregulável.

Tais autores argumentavam que a economia de mercado poderia funcionar regida por ela mesma, sem a intervenção ou a intromissão de qualquer outra esfera, como se ela respondesse a uma inclinação natural do Homem ao mercado, à busca do lucro, o que justificaria a existência de uma economia destituída de responsabilidade para com a sociedade e regulada por suas próprias leis.

Diferente desta visão, Polanyi observa que, de fato, a economia sempre foi uma dimensão de suma importância na história social humana. No entanto, suas motivações, diretrizes e objetivos sempre estiveram subordinados aos interesses sociais. Nesse sentido, o discurso que defendia a existência de uma economia de mercado que funcionasse apenas para o mercado, desvinculada de sua natureza e responsabilidade coletiva, torna-se uma falácia insustentável (POLANYI, 2012).

A ideia do mercado autorregulado, aquele que Betinho observa como um empecilho à realização da democracia por não ter em suas pretensões fundamentais a inclusão de todo o conjunto da sociedade, é semelhante ao que Polanyi busca desconstruir em sua análise, observando como tal discurso, longe

\footnotetext{
${ }^{11}$ Adam Smith (1723- 1790), Filósofo e economista inglês, um dos pais da teoria do liberalismo econômico, desenvolvida em duas de suas mais importantes obras. A "Teoria dos sentimentos morais" onde o autor esclarece sua visão dos comportamentos sociais que funcionariam como base das ações coletivas. E na "Riqueza das nações" o autor defende a ideia de que o livre mercado e a acumulação de capitais estaria na base do desenvolvimento econômico das nações. Suas ideias foram lidas, de forma a identifica o Smith como expoente maior da defesa do livre mercado, de um mercado auto regulado.
} 
de responder a uma pretensa natureza humana, estava ligado a uma concepção de sociedade forjada há alguns séculos apenas.

Na perspectiva colocada por Polanyi, uma opção para a autorregulação do mercado estava em ser equilibrada pela regulação da sociedade através do Estado.

A partir das ideias de Betinho expostas até aqui, pode-se observar que também haveria uma crítica sua quanto à regulação do mercado pela via do Estado, caso ela ocorresse através de uma configuração de Estado que estivesse desvinculado da participação social.

Apesar das diferenças entre as duas visões com relação a possíveis soluções para a superação do livre mercado, pode-se observar que ambos concordam a respeito da problematização de uma sociedade organizada e controlada unicamente a partir da perspectiva do livre mercado.

A defesa da independência de um mercado autorregulável de Smith, baseada na ideia hobbesiana de natureza humana, de que todos os homens seriam naturalmente individualistas e possessivos, como base fundamental para a defesa da criação de um mercado autorregulável - sem possuir função social -, constitui uma invenção dos séculos XVIII e XIX, a que o autor classificou de "grande transformação" (POLANYI, 2012).

Polanyi observa como o liberalismo econômico passou a julgar e a avaliar os acontecimentos sociais sob um ponto de vista estreito e o quanto algumas sociedades ocidentais compraram este discurso, historicamente datado, como pretensamente universal:

\footnotetext{
O liberalismo econômico interpretou mal a história da revolução industrial porque insistiu em julgar os acontecimentos sociais a partir de um ponto de vista econômico (...). A economia de mercado é uma estrutura institucional, e sempre nos esquecemos disto, que nunca esteve presente a não ser em nosso tempo e, mesmo assim, ela estava apenas parcialmente presente (POLANYI, 2012, p. 36 e 40).
}

Esta concepção inaugurada pela utopia do livre mercado, cuja economia possui vida própria, separada da sociedade e destituída de responsabilidades sociais, é, em boa medida, retomada por Betinho para pensar as severas limitações da 
sociedade capitalista no que diz respeito à garantia dos direitos fundamentais dos integrantes da sociedade como um todo, não apenas aos beneficiários do mundo do capital.

Tomando partido nesta discussão, Betinho faz objeções às economias capitalistas, alinhadas à utopia do livre mercado pelo fato de que elas, em sua visão, pensariam em si mesmas - desconsiderando a sociedade como um todo -, reduzindo a visão da sociedade à visão do capital, os problemas da sociedade aos problemas do capital. A lógica também dá-se inversamente, tudo que não constitui um problema do capitalismo, deixa de ser um problema da sociedade (SOUZA, 1987, p. 14; SOUZA, 1991, p. 50).

Para Betinho, o problema do capitalismo estava no fato de ele não ser capaz de garantir que os frutos do desenvolvimento econômico fossem mais bem distribuídos para o conjunto da sociedade.

Um exercício de reflexão útil para pensar a incapacidade da sociedade capitalista em garantir um projeto que contemplasse e englobasse todos os grupos da estrutura social é observada na análise de Sennett (2012 a). Nela, o argumento central encontra-se na análise das mudanças da organização do trabalho, da produção ao longo do século XX e suas consequências nas experiências pessoais e na construção do caráter, compreendido como a ligação dos indivíduos com o mundo.

Nessa reorganização do mundo do trabalho, passa-se de uma organização produtiva rígida, linear e estável para uma organização descontínua, mutável e incerta, que o autor classifica de "capitalismo flexível”.

Além deste argumento central, Sennett traz, no encerramento de sua análise, uma questão que aparece como pano de fundo para pensar os limites da sociedade capitalista, que se pode, em boa medida, aproximar ao argumento de Betinho.

Em sua visita ao Fórum Econômico Mundial de Davos ${ }^{12}$, Sennett relata como os próprios representantes do mundo do capital se sentiam pouco à vontade, ou

\footnotetext{
${ }^{12}$ Fórum Econômico Mundial, organização sediada em Genebra fundada em 1971, que realiza reuniões anuais na cidade de Davos na Suíça, reúne grandes empresários e chefes de Estado para
} 
mesmo incomodados quando eram questionados sobre as muitas pessoas que tal sistema não era capaz de incluir ou sobre aquelas que, no máximo, orbitavam perifericamente nas bordas das estruturas econômicas.

Nessa perspectiva, no seio do capitalismo flexível, produzido a partir da década de 1970, constitui-se uma visão de projeto de sociedade em que se aprofundam os problemas daqueles indivíduos que se encontram fora da órbita do capital, sendo ignorados por ele. $\mathrm{O}$ ataque do capitalismo flexível às redes de proteção e direitos impõem-se cada vez mais como uma necessidade de sobrevivência do próprio sistema às custas da degradação do tecido social (SENNETT, 2012, p. 167 a).

Na conclusão de sua análise, Sennett observa como o "nós" se constitui como um pronome perigoso, pois, para o mundo do capital, em sua nova configuração flexível de fins do século XX, já não admite sequer a construção de um sentimento de coletividade, de uma base comum. Ao contrário, fomenta uma competitividade que exclui a maioria das pessoas, na qual a construção de uma identidade comum é sacrificada para dar lugar à constante e perturbadora flexibilidade essencialmente excludente.

Relatando a partir de seu argumento a experiência que teve ao visitar o fórum econômico de Davos, Sennett, ao observar o comportamento dos representantes do novo mundo do capital, relata ter tido:

\begin{abstract}
uma espécie de epifania em Davos, ouvindo os governantes do reino flexível. Também para eles, "nós" é um pronome perigoso. Eles habitam confortavelmente a desordem econômica, mas temem o confronto organizado. Temem, claro, o ressurgimento dos sindicatos, mas ficam aguda e pessoalmente desconfortáveis, mexendo-se ou evitando olhar nos olhos, ou retirando-se para trás de anotações, se obrigados a discutir as pessoas que, em seu jargão, foram "deixadas para trás"(SENNETT, 2012, p. 176 a).
\end{abstract}

Neste mundo, deixam de constituir uma questão aqueles que se encontram fora do mercado, do trabalho e da economia. Como já dito anteriormente, Betinho observa a incompatibilidade da realização da democracia numa sociedade

discutir questões sobre economia, desenvolvimento, meio ambiente, etc. Conforme o passar dos anos ganhou cada vez maior notoriedade, constituindo-se informalmente como uma espécie de reunião geral dos grandes gestores mundiais do capitalismo. 
capitalista como a brasileira, por exemplo, pelo fato de que se existiam 50 milhões de pessoas em situação de indigência fora da órbita do mercado ou inseridos de forma periférica, uma vez que isto não constitui um problema para o mercado que postula dirigir a sociedade. Betinho defendia, para criar as condições de possibilidade da existência de sua concepção de democracia, pensar a sociedade por ela mesma, pelos interesses de todos e não pelas condições estabelecidas pela lógica capitalista:

\begin{abstract}
Pensar fora da lógica do capital significa pensar positivamente uma sociedade fundada em outra forma de relação social de produção. Significa extrair a sociedade do mundo das relações sociais capitalistas e transpô-la como projeto, como processo e como utopia para um mundo de relações sociais positivamente definidas (não capitalistas). Essa extração é um ato político, ao mesmo tempo abstrato e concreto, presente e futuro, atual e potencial (...). Os três princípios da democracia (igualdade, diversidade e participação) negam o capital na medida em que ele se funda numa relação que nega a igualdade, a diversidade e a participação. Isto porque o capital sobrevive através da apropriação privada dos meios de produção, da exclusão dos não proprietários do mundo dos que decidem sobre o que e como produzir para a sociedade (SOUZA, 1987, p. 14 e 15).
\end{abstract}

A proposição utópica feita por Betinho para a edificação de uma sociedade democrática que mobilizasse seu conceito de democracia está na reunião das dimensões que a sociedade do livre mercado teria separado e/ou invertido os valores. A ética deveria ser o princípio das relações econômicas e políticas, assim como a política - com sua força baseada na sociedade - é que deveria direcionar a economia, não o oposto. E para construir uma sociedade fundamentalmente democrática, seria necessário subordinar a economia à política e a política à ética (SOUZA, 1987, p. 97).

Passamos então à conclusão deste capítulo, que teve como objetivo expor brevemente a biografia de Betinho, não apenas por ser personagem central deste trabalho, mas pelo fato de a evolução de suas ideias, sobretudo o esclarecimento de sua concepção de democracia, ajudar-nos em muito a iluminar o que posteriormente constituiu o caráter fundamental da Campanha da Ação da Cidadania. 
Esta exposição nos conduz ao aspecto mais fundamental deste trabalho, o de entender a Campanha à luz do desenvolvimento das ideias de seu principal organizador. Longe de constituir um episódio acidental, ela estabelece-se como ação prática de um conjunto de ideias que vinham se desenvolvendo em Betinho desde a experiência do exílio no Chile.

Nestas mudanças observadas em sua trajetória, Betinho transfere-se de uma luta, em que o combate às injustiças e desigualdades deixa de ser tomado pelo Estado e somente por ele mesmo como aspecto mais importante para vislumbrar sua modificação através da sociedade.

Deixa o horizonte do Estado em si mesmo, para vislumbrar o horizonte de um Estado constituído pela participação, mobilização e pressão da sociedade. Só faria sentido pensar no Estado se fosse pela via da sociedade e a partir de sua concepção de democracia.

Sua diferença com a limitação da sociedade capitalista manteve-se preservada, mas sua forma de luta contra ela se modificou. Sua concepção de democracia estava agora fundada em cinco bases fundamentais, sem as quais ela não se realizaria: igualdade, liberdade, participação, solidariedade e diversidade.

Somente a partir desses valores se poderia edificar uma sociedade fundamentalmente democrática. A democracia só poderia existir para Betinho junto com a cidadania.

Sua concepção de democracia funda-se no uso da economia à serviço do bem comum como princípio fundamental, à serviço da cidadania e da incorporação de todos. Ou a sociedade incluía todos, ou ela não serviria para nada.

Nesse conjunto de princípios, não necessariamente se espera pelo Estado. A sociedade poderia e deveria tomar a dianteira deste processo, que deveria ser de baixo para cima e não o oposto. Esta importante compreensão é observada em Betinho no processo de formação e efetivação da Campanha Contra a Fome que será apresentada no capítulo seguinte. 


\section{Ação da cidadania como desdobramento da descoberta da sociedade civil}

No capítulo anterior, buscou-se esclarecer como da trajetória de Betinho emergiu um conceito fundamental, o de democracia. Neste, buscar-se-á observar como surgiu em sua trajetória outro conceito fundamental, o de sociedade civil, dimensão que exerceu importante influência na realização de um dos feitos mais notáveis em sua vida, a Campanha da Ação da Cidadania.

Analisando a maneira pela qual Betinho incorporou a importância da participação da sociedade civil para a transformação do país, pode-se notar como a experiência da Campanha da Ação da Cidadania materializa-se como exemplo empírico, uma vez que todo eixo da Campanha tinha como principal interlocutor a sociedade civil.

Neste capítulo, procura-se entender como o encontro de Betinho com a concepção da centralidade da mudança localizada no eixo da sociedade redunda na construção e edificação da Campanha da Ação da Cidadania.

A grande fonte de inspiração para a natureza ontológica da campanha, parte de uma visão crítica da centralidade do Estado - visto no capítulo anterior - como agente central de mudanças e intervenções, para a própria sociedade como agente fundamental na mudança da estrutura social, na qual a sociedade civil possui papel importante.

A busca dos elementos motivadores iniciais da Campanha na própria trajetória de Betinho conduz-nos a um redimensionamento realizado em seu pensamento, em que na relação Estado x sociedade, que até sua ida ao exílio pendia mais para o lado do Estado, transforma-se, após seu regresso, com maior relevância, na sociedade como importante ator social na realização das transformações.

Sem negar a importância do Estado, Betinho incorpora a noção de que a sociedade (civil) constitui agente imprescindível no processo de mudança social. 
Para identificar com maior clareza a natureza do uso do termo "sociedade civil”, realizar-se-á uma breve reconstituição da utilização deste termo no pensamento social clássico e contemporâneo. No pensamento social clássico, busca-se identificar como este conceito foi compreendido no pensamento de Hegel, Marx e Gramsci ${ }^{13}$, autores do pensamento social que, nos últimos três séculos, cunharam análises a respeito deste termo, além de estabelecerem bases teóricas fundamentais para o pensamento da esquerda.

Observar-se-á, de maneira sucinta, como a ideia de sociedade civil foi tratada no decorrer do século XX, sobretudo a partir das contribuições de Sergio Costa e Habermas, buscando pontuar os elementos mais importantes com relação à ideia de sociedade civil.

O conjunto de análises sobre a ideia de sociedade civil no século $\mathrm{XX}$ - contexto contemporâneo - busca organizar como, sob distintas visões, se observou e compreendeu tal ideia, além de contribuir com a compreensão de como os eventos históricos recentes ajudaram a moldar seu conceito.

Será também exposto, de forma breve, como os caminhos de sua incorporação foram historicamente compreendidos no contexto brasileiro, coincidindo com a transição para a democracia e o fim da ditadura militar.

Também apresentaremos uma concepção contemporânea a Betinho, sobretudo a colocada por Alan Wolfe, que no entendimento deste trabalho, mais se aproxima da perspectiva de sociedade civil pensada por ele.

Apresenta-se também a experiência da Campanha da Ação da Cidadania Contra a Fome, a Miséria e Pela Vida, observando seu alcance, amplitude, objetivos e sua natureza específica; como ela emergiu e estruturou sua atuação a partir de um discurso novo, de chamamento à sociedade; como ela vislumbrava modificar a estrutura social, sobretudo a partir da participação da sociedade.

Por fim, a experiência da campanha será analisada como o clímax da materialização da aposta de Betinho na sociedade que, como vista no capítulo

\footnotetext{
${ }^{13}$ Apesar de cronologicamente situar-se no pensamento contemporâneo, tomo a análise de Gramsci como integrante da mesma matiz e importância de Hegel e Marx.
} 
anterior, se inicia em sua trajetória desde o exílio. A campanha traz para a cena pública a ideia de "radicalização da democracia", mesmo na década de 1990, quando o cenário brasileiro iniciava seu processo de consolidação, período em que Betinho trouxe o discurso fundamental de aprofundamento da experiência democrática e como ela não combinava, nem poderia coexistir com os alarmantes e vergonhosos índices de miséria e desigualdades.

\subsection{Sociedade civil para Hegel, Marx e Gramsci}

Apesar de a expressão "Sociedade civil" aparecer desde os escritos de Aristóteles, que, ainda na Grécia Antiga, era compreendida como uma comunidade política, foi apenas no século XVIII que se propôs uma redefinição da ideia de sociedade civil, geralmente associando-a como uma esfera separada, ou mesmo como uma proteção ao Estado. Passando por Kant e Rousseau, que a compreenderam como uma oposição ao estado de natureza, é com Hegel que ela adquire um estatuto teórico (COSTA, 2002, p. 38).

As análises de Hegel, Marx e Gramsci sobre a ideia de sociedade civil são trazidas aqui como elementos para pensar como ela foi pensada historicamente. Também pelo fato de que o pensamento, sobretudo, de Marx e Gramsci parte de linhagens mais próximas com as quais Betinho dialogou a maior parte de sua vida.

\section{Sociedade civil para Hegel}

É com Hegel, no início do século XIX, que se concebe uma definição mais apurada para o conceito de sociedade civil. Inicialmente situada na transição do particularismo da família para o Estado - instituição que, para Hegel, constituía o momento de realização da natureza social humana -, a sociedade civil representaria o momento de sucessão, de superação da esfera familiar em direção aos interesses organizados por meios de grupos e classes na sociedade. A partir da 
esfera dos interesses econômicos, as classes e grupos com interesses particulares constituiriam na sociedade civil uma esfera de organização dos interesses coletivos (TONET, 2006, p. 2).

No momento de percepção da incapacidade da família e do próprio Estado de instituírem uma esfera da criação de um princípio ético comum e uma visão particular surge uma instituição intermediária, que Hegel compreende como a sociedade civil:

Hegel é, todavia, o primeiro autor moderno em cuja obra a ideia de sociedade civil cumpre um papel fundamental. Hegel reconhece que nem a família nem o Estado são capazes, nas sociedades modernas, de estabelecer o conjunto das determinações para a vida dos indivíduos. Entre a família e o Estado, surge um conjunto de instituições, o sistema das necessidades, a administração da justiça e as corporações. (...). Sociedade civil para Hegel implica, simultaneamente, as determinações egoístas e individualistas provenientes da ação dos indivíduos no interior do sistema das necessidades e a procura de um princípio ético que, para Hegel, jamais poderia ser proporcionado pelo mercado (AVRITZER, 1993, p, 218).

A esfera da sociedade civil em Hegel é percebida como etapa posterior à esfera familiar, cuja interação dos indivíduos constitui a busca pela satisfação dos interesses ainda particulares, assim como posteriormente caminha para o reconhecimento da necessidade dos outros para a realização pessoal.

De uma organização visando à realização dos interesses privados, a sociedade civil passa à esfera do reconhecimento da organização coletiva como meio de defesa dos interesses particulares (MOREIRA NETO, 2010, p. 39). A sociedade civil seria a esfera na qual os indivíduos compreenderiam que as interações e associações constituem a principal forma de defender os interesses individuais.

Essa dupla visão ou dicotomia ao analisar a sociedade civil em momentos diferentes é observada também por Sergio Costa, em que:

Por um lado, a sociedade civil incorpora o sistema de necessidades dentro do qual os indivíduos perseguem seus próprios interesses, produzindo consequências negativas para a preservação do espírito público e dos laços de solidariedade social. Ao mesmo tempo, a sociedade civil hegeliana compreende organizações intermediárias e associações (corporações) que representam o suporte fundamental de uma nova eticidade (COSTA, 2002, p, 38 e 39). 
Compreendida no momento de passagem, do que para Hegel se encontrava escalonado do simples ao complexo, a sociedade civil representava um momento de aglutinação de interesses comuns, de formação de um espírito público, ainda que motivado por interesses particulares. Esta esfera se encontrava fora do Estado, como que em um degrau abaixo dele.

Pode-se observar que, na formulação de Hegel, este confere ao conceito de sociedade civil uma elaboração mais significativa, situando-a entre a família e o Estado; uma esfera diretamente resultante das especificidades da era moderna, incorporando esferas sociais como economia e administração pública por exemplo. Constituída por organizações intermediárias que por um lado se oporiam ao particularismo do mercado e por outro contribuiriam para a promoção de um “espírito público" (COSTA, 2002, p. 38 e 39).

\section{Sociedade civil para Marx}

Já Marx estruturou sua ideia de sociedade civil inserida, sobretudo, na perspectiva crítica àquela de Hegel, em relação não apenas à concepção de sociedade civil, mas da sociedade em geral.

Objetivando consolidar sua concepção de sociedade em oposição a Hegel e seus seguidores, a concepção de sociedade civil pode ser compreendida no bojo da crítica geral de Marx ao projeto de idealismo hegeliano. Marx coloca o primado da compreensão das estruturas sociais nas relações materiais, que por sua vez condicionariam as instituições e a política. Inscrita na crítica à visão essencialmente idealista da história presente em Hegel, a concepção de sociedade civil aparece como uma esfera real, efetiva, de relações materiais que compõem a própria estrutura da sociedade burguesa:

A forma de intercâmbio, condicionada pelas forças de produção existentes em todos os estágios históricos precedentes e que, por seu turno, as condiciona, é a sociedade civil (...). Aqui já se mostra que essa sociedade civil é o verdadeiro foco e cenário de toda a história, e quão absurda é a concepção histórica anterior que descuidava das relações reais, limitando-se às pomposas ações dos príncipes e dos Estados (...). Essa concepção da história consiste, portanto, em desenvolver o processo real de produção a partir da produção material 
da vida imediata e em conceber a forma de intercâmbio conectada a esse modo de produção e por ele engendrada, quer dizer, a sociedade civil em seus diferentes estágios, como o fundamento de toda a história (MARX e ENGELS, 2007, p.39 e 42).

Logo, a ideia de sociedade civil, em Marx, aparece relacionada à sociedade burguesa como o campo no qual se dão as relações materiais efetivas que corporificam as estruturas da sociedade burguesa.

De forma semelhante, Sergio Costa (2002) observa como Marx coloca sua ideia de sociedade civil como elemento a pontuar sua crítica ao idealismo hegeliano, afirmando sua concepção da centralidade das relações materiais. Nesse sentido, longe de representar uma esfera genérica ou intermediária, como postularia Hegel, a sociedade civil constituiria mais um espaço de reafirmação dos interesses das classes dominantes. Muito longe de se identificar como uma esfera independente de aglutinação de interesses, ela se encontraria capiturada pelos interesses da classe hegemônica:

\begin{abstract}
Nesse sentido, à sociedade civil não aparece associada qualquer possibilidade de aglutinação de uma nova eticidade. $\mathrm{Na}$ ordem capitalista, a sociedade civil constitui a um só tempo a fonte e a expressão do domínio da burguesia. As instituições intermediárias que, para Hegel, atuariam como contraponto - no sentido da promoção do espírito público - ao particularismo alimentado pelo mercado representam para Marx uma outra forma de manifestação do subjugo da classe trabalhadora (COSTA, 2002, p. 39).
\end{abstract}

Temos, então, que o conceito de sociedade civil em Marx aparece associado à sociedade burguesa. Para ele, não está colocada a ideia de sociedade civil como uma esfera de participação inovadora. Em Marx, ela encontra-se subsumida nas determinações da esfera da infra-estrutura.

O que Hegel enxergou como uma possibilidade de instituição intermediária entre o particular (família) e o geral (Estado), constituído em sua ideia de sociedade civil, Marx compreendeu como mais um epifenômeno da condição geral da estrutura social de preponderância da burguesia, que tornaria a sociedade civil uma esfera constituinte de sua dominação. A sociedade civil, em Marx, pertence ao reino da sociedade burguesa, funcionando para ela. 


\section{Sociedade civil para Gramsci}

O sociólogo italiano Antonio Gramsci (1891-1937), também pertencente à tradição marxista, incorporou em suas análises um espaço para conceituar sociedade civil. Apesar de marxista, Gramsci foi responsável por conferir à sociedade civil um conceito elaborado sob outra perspectiva.

Se para Marx, a sociedade civil encontrava-se unicamente no reino da infraestrutura, em Gramsci ela encontra-se presente em outra esfera, em outro momento da vida social, o da superestrutura (COUTINHO, 1999, p.121).

Assim como Marx, Gramsci entende a estrutura social formada pelo universo da vida material (infra-estrutura) e das ideias e instituições fomentadoras de consenso (superestrutura), em que a primeira condiciona a segunda.

A novidade em Gramsci é que a ideia de sociedade civil aparece também no reino da superestrutura que se divide em duas partes: uma que o autor classifica de sociedade política, a esfera efetiva de dominação do Estado; e outra classificada de sociedade civil, esfera onde se produziriam a dominação por meio das ideias e do consenso, adquiridas através do que Gramsci classificou de "aparelhos privados de hegemonia"14.

Este entendimento de distintas concepções no reino da superestrutura se insere no conceito de Estado ampliado reivindicado por Gramsci, no qual o Estado, no contexto das sociedades ocidentais do século XX, não poderia ser compreendido apenas por seu caráter de força impositiva. Mas, o surgimento dos modernos meios de comunicação e de novas tecnologias fazia com que o domínio do Estado necessitasse ser compreendido por outros aspectos além da força física (COUTINHO, 1999, p.124; MOREIRA NETO, 2010, p.44).

\footnotetext{
${ }^{14}$ Por "aparelhos privados de hegemonia", Gramsci compreendia o conjunto das organizações responsáveis pela elaboração e/ou difusão de ideologias, de sistemas de crenças que, apesar de controlados por entes distintos era responsável por difundir ideias e visões de mundo.
} 
São nesses novos mecanismos de dominação através do consenso, da opinião em que se encontram o lugar da sociedade civil. Ela, em certo sentido, integra a concepção de Estado ampliado em Gramsci:

\begin{abstract}
Portanto, o Estado em sentido amplo, 'com novas determinações' comporta duas esferas principais: a sociedade política (que Gramsci também chama de 'Estado em sentido estrito' ou de 'Estado coerção'), que é formada pelo conjunto dos mecanismos através dos quais a classe dominante detém o monopólio legal de repressão e da violência e que se identifica com os aparelhos de coerção sob controle das burocracias executiva e policial militar; e a sociedade civil formada precisamente pelo conjunto das organizações responsáveis pela elaboração e/ou difusão das ideologias, compreendendo o sistema escolar, as igrejas, os partidos políticos, os sindicatos, as organizações profissionais, a organização material da cultura (revistas, jornais, editoras, meios de comunicação de massa), etc. (COUTINHO, 1999, p. 127).
\end{abstract}

Sem negar o primado da dimensão material para a construção da hegemonia de uma classe sobre outra, Gramsci confere um papel mais importante ao plano cultural, da moral, das ideias, observando como a dominação de uma classe possui um caráter complexo de múltiplas facetas.

A preponderância para Gramsci conquista-se, sobretudo, no plano cultural, observada na capacidade de uma classe adquirir o consenso moral e intelectual da sociedade a partir de um projeto que lhe favoreça. Para Gramsci, a disputa entre as classes pela conquista de hegemonia, do consenso, ocorre no reino da sociedade civil (COSTA, 2002, p. 40).

A sociedade civil aparece como a esfera do embate pela preponderância de determinada classe social, em que são constituídos os consensos. Era a dominação cultural que permitiria a uma classe se tornar hegemônica sem fazer uso contínuo da força.

Uma das grandes contribuições de Gramsci para a compreensão da dominação do Estado, observa, está em buscar compreendê-lo para além de suas características coercitivas, já amplamente analisadas pelos clássicos do pensamento social, mas de buscar outros fundamentos de sua natureza, chegandose assim à sociedade civil (COUTINHO, 1999, p. 128). 
Este conceito pensado em Marx e Gramsci, através de diferentes enfoques, remete, entretanto, à esfera do domínio da classe hegemônica (a burguesia). Seja na infra ou na superestrutura, a sociedade civil é percebida como um epifenômeno da luta de classes antagônicas na sociedade, atrelada à classe hegemônica na sociedade.

Conforme exposto no início deste capítulo, as compreensões dos autores citados a respeito da ideia de sociedade civil constituem elementos iniciais para se pensar o tratamento histórico deste termo.

\subsection{Sociedade civil no contexto contemporâneo}

Em contextos contemporâneos, o emprego do termo sociedade civil tem sido novamente utilizado para significar distintas situações nas sociedades ocidentais. Dentre eles, destaco três contextos específicos que Sergio Costa (2002) chama a atenção para sua inserção nas últimas décadas do século XX.

As duas primeiras dizem respeito ao emprego da ideia de sociedade civil como instância de defesa frente a um Estado forte ditador e/ou totalitário representado pelas ditaduras do chamado terceiro mundo, assim como os países sob a influência do stalinismo no Leste Europeu. No entanto, mesmo em contextos de experiências democráticas, podem-se notar reconfigurações sobre a perspectiva de sociedade civil.

Essa perspectiva de sociedade civil aparece em países capitalistas em contextos autoritários. Neles, ela aparece como uma espécie de defesa contra o Estado. Exemplos dessa tipologia de Estado foram constatados em vários países sulamericanos nas décadas de 1970, 80 e 90, encontrando-se assolados por governos ditatoriais. A ideia de sociedade civil representava um "desafogo" contra o Estado opressor:

No plano político, a recente revivificação do debate sobre a sociedade civil está associada a acontecimentos diversos. Inicialmente, o conceito ressurge no Leste Europeu nos anos 1970 e reflete a resistência à onipresença do Estado socialista real e às restrições às 
possibilidades de organização soberana da sociedade (civil). Também na América Latina, a retomada do conceito está associada à resistência contra os regimes autoritários (COSTA, 2002, p. 42).

O outro diz respeito aos países do Leste Europeu que compunham a antiga União Soviética (URSS) sob o regime stalinista, cujo Estado representava quase a totalidade da vida social a todo o momento. Nesse contexto, os debates em torno do conceito de sociedade civil emergem como expressões de questionamento a este Estado todo poderoso (COSTA, 2002, p.49; WOLFE, 1991, p.40).

O renascimento desta expressão não se reduziu a contextos de sociedades com Estados autoritários. Mesmo em sociedades ditas democráticas com desenvolvido grau de participação política e redes de proteção social - com Welfare State $^{15}$-, surge a percepção da insuficiência da burocracia estatal para a compreensão e enfrentamento da totalidade dos problemas sociais, este seria o terceiro contex to de inserção da ideia de sociedade civil no século XX.

A ideia de sociedade civil aparece também como meio de contestar as formas clássicas - sobretudo pela via dos partidos políticos - de ação política, indicando que essas instâncias já não eram capazes de atender satisfatoriamente às demandas reivindicadas por amplos setores da população que passaram a buscar outras esferas de participação, tendo em vista que a tutela política do Estado social muitas vezes transformava os indivíduos em meros receptores das benesses do Estado (COSTA, 2002, p. 43).

Esta última concepção de sociedade civil, apesar de não refletir o contexto brasileiro $^{16}$, parece-nos aquela que, como veremos adiante, mais se aproxima da ideia de Betinho sobre o conceito e utilidade da categoria de sociedade civil. O conceito que orienta suas diretrizes para suas ações nas décadas seguintes.

\footnotetext{
${ }^{15}$ Welfare State, ou Estado de Bem Estar social, criado e desenvolvidos na década de XX sobretudo nos Estados europeus, tinha como objetivo criar uma ampla rede de proteção social a partir da assistência do Estado aos que mais necessitavam.

${ }^{16}$ Pois em fins da década de 1970, o contexto sócio político brasileiro encontrava-se caracterizado pelo início do fim de uma ditadura militar, o que tornava as demandas da "sociedade civil brasileira" distintas dos países com Estado de Bem Estar Social.
} 
Apesar de seu contundente reexame crítico a respeito do papel do Estado na realização das mudanças sociais, quando Betinho abandona uma visão estreita de que apenas a partir do Estado se poderia mudar, passando a compreender também que a sociedade poderia constituir uma arena fundamental de produção de mudanças, a preocupação com a democratização do Estado jamais deixa de existir em seu horizonte. Seu reexame o leva a buscar este objetivo através de outros caminhos.

Apesar de problematizar o papel e a relevância do Estado, Betinho jamais deixou de reconhecer que era para o Estado que a sociedade deveria mirar a efetivação das mudanças desejadas, sendo imperativa a necessidade de democratização do Estado pela sociedade.

Nesse sentido, o Estado nunca desapareceu do horizonte de pensamento de Betinho, mas foi colocado em seu "devido lugar", como um ente subordinado à sociedade. Na relação Estado $\mathrm{x}$ sociedade, as duas dimensões permanecem fundamentais para Betinho, no entanto, a sociedade passa a ter um papel de protagonismo que anteriormente não tinha.

Outra importante plataforma para pensar a classificação deste termo se encontra na abordagem habermasiana, que dedicou importantes análises sobre a moderna concepção de espaço público e sociedade civil. Em suas análises, Habermas concebia esfera pública como uma instância de constituição de relações de poder organizadas no mundo público, no entanto, fora da alçada do Estado instituído uma instância separada do Estado e dos interesses privados (do mercado).

A esfera pública compreenderia o contexto público comunicativo, onde os membros de uma comunidade política englobam condições de convivência conjunta e buscam a partir de demandas distintas, possibilidades de solução de problemas vividos socialmente (COSTA, 2002, p. 27).

Apesar de, na abordagem de Habermas, a gênese da esfera pública, que nos ajuda a pensar o papel da sociedade civil, se encontrar ainda no capitalismo mercantil da Europa do século XVII, ela é percebida e caracterizada como uma 
instituição que não se confunde nem com o Estado, nem com o mercado (PERLATTO, 2012, p. 79 e 80).

A esfera pública como espaço de organização dos interesses coletivos, mediada por sua ação comunicativa, ajuda a pensar, nas sociedades ocidentais, a chegada de demandas dos grupos sociais organizados por uma via distinta do Estado.

A criação das condições objetivas ao surgimento de uma esfera pública autônoma em relação à esfera estatal dá-se na fase de evolução da sociedade burguesa. A partir desta organização social que legitima a possibilidade de intercâmbios materiais, estabelece-se a esfera pública como instrumento socialmente compreendido (HABERMAS, 1984, p. 93)

Nesse sentido, Sergio Costa observa também que, em Habermas, o poder e a capacidade de organização da sociedade civil se encontram na medida de sua desvinculação com o poder estatal instituído. Sua influência deve-se fazer sentir por outros meios:

O poder conferido à sociedade civil não deve estar associado (...) à ideia de um povo concreto que tem no Estado sua corporificação institucional. Há que se manter a distinção entre a esfera societária e a esfera política e o Estado, de sorte que a influência da sociedade civil se concretize de forma anônima e difusa por meio da existência de uma esfera pública transparente e porosa, permeável às questões originadas no mundo da vida (COSTA, 2002, p. 26).

A condução dos indivíduos do "mundo da vida"17 para o mundo da esfera pública caberia à sociedade civil, que cumpria na sociedade a função organizadora de uma instância na qual os grupos organizados exporiam suas demandas no mundo público.

Outra contribuição de Habermas para se pensar o lugar da sociedade civil nos contextos sociais contemporâneos é dada a partir de seu lugar numa concepção republicana de processo democrático. Habermas (1995), ao distinguir o liberalismo do republicanismo a partir do papel atribuído por cada um à função do

\footnotetext{
17 O mundo da vida correspondia na perspectiva de Habermas à dimensão onde os indivíduos organizam e formam suas identidades, tornando-se capazes de compreender os sentidos que elas próprias conferem às suas ações. Perlatto, 2012, p. 81.
} 
processo democrático, observa na concepção republicana um lugar importante para a sociedade civil. Um elemento de integração social distinto do Estado e do mercado:

Para a prática da autodeterminação cidadã supõe-se uma base de
sociedade civil autônoma, independente tanto da administração
pública como do intercâmbio privado que protegeria a comunicação
política da absorção pelo aparato estatal ou da assimilação à estrutura
do mercado. Na concepção republicana o espaço público e político e a
sociedade civil como sua infraestrutura assumem um significado
estratégico. Eles tem a função de garantir a força integradora e a
autonomia da prática do entendimento entre os cidadãos (HABERMAS, 1995, p.40).

Esta perspectiva, assim como as demais observadas, nos ajuda a identificar como o pensamento social contemporâneo ofereceu numerosas possibilidades para se analisar o papel da sociedade civil nas sociedades contemporâneas, ajudando a compor a visão que Betinho teve de sociedade civil como instância de organização e ação dos grupos sociais para além do mercado e do Estado.

\subsection{Sociedade civil no contexto brasileiro}

A inserção deste conceito no Brasil esteve intimamente relacionada à resistência à ditadura militar. Neste caso, ela aproxima-se da realidade observada acima, dos países do Leste Europeu, que tinha no Estado seu inimigo e a personificação do poder autoritário.

As leituras sobre a incorporação do conceito de sociedade civil no Brasil ressaltam sua inserção mais pela via da necessidade de oposição ao Estado que propriamente a emergência de uma esfera autônoma e independentemente organizada; ou mesmo pela simples e urgente necessidade de organização dos perseguidos pelo Estado autoritário (COSTA, 2002, p.55; WEFFORT, 1984, p.93 e 95). 
Weffort observa que sua inserção, inicialmente após o golpe civil militar - que suprimiu as instâncias e instituições de participação política -, se fez devido a satisfação das necessidades mais urgentes aos opositores do regime. A sociedade civil aparece primeiramente como suprimento de necessidades em sua forma mais "molecular":

\begin{abstract}
A decepção, mais ou menos generalizada, com o Estado abre caminho, depois de 1964 e, sobretudo, depois de 1968, à descoberta da sociedade civil. Mas nem por isso terá sido, em primeiro lugar, uma descoberta intelectual. Na verdade, a descoberta de que havia algo mais para a política além do Estado começa com os fatos mais simples da vida dos perseguidos. Nos momentos mais difíceis eles tinham de se valer do que encontravam à sua volta. Não haviam partidos aos quais se pudesse recorrer, nem tribunais nos quais se pudesse confiar (WEFFORT, 1984, p. 93).
\end{abstract}

Para Costa, as necessidades empíricas superaram a fase de organização conceitual, apropriando-se delas para combater o inimigo maior, o Estado autoritário:

\begin{abstract}
A utilização da expressão sociedade civil nesse caso remete-nos ao sentido coloquial do termo, como não militar, estabelecendo uma linha divisória entre a sociedade (civil) e o Estado (militar). Enquanto concepção política, a sociedade civil representava, no início dos anos 70 , uma plataforma de sustentação fundamental para o projeto de oposição ao regime militar. Com isso, a discussão sobre a plausibilidade empírico-analítica da categoria ficava relegada a um plano secundário. Ou seja, não cabiam especulações sobre a existência de uma sociedade civil no Brasil, buscava-se um marco conceptual capaz de dar suporte à organização da resistência contra os militares (COSTA, 2002, p.55).
\end{abstract}

Sergio Costa cita o próprio Weffort (1984), que afirma categoricamente que a sociedade civil no caso brasileiro parte, primeiramente, de uma grande necessidade real, antes de teórica.

No entanto, se por um lado é correta a análise dos autores, por outro, pode-se objetar também que, já no contexto de fins da ditadura e de redemocratização no início da década de 1980, a percepção da limitação do Estado - seja por seu caráter historicamente autoritário, seja por sua falta de comunicação e agendas para com os setores mais empobrecidos - coloca a ideia de que não apenas a 
redemocratização ou a derrota dos militares seria suficiente para a democratização da sociedade.

As postulações de Costa e Weffort, apesar de iluminar o tema da inserção do conceito de sociedade civil no contexto brasileiro, para efeitos deste trabalho não se aplicam em sua integralidade. Pois, como será exposta, no caso de Betinho, a importância da ideia de sociedade civil sobrevive ao fim da ditadura e ao próprio processo de redemocratização, constituindo a década de 1990 como o grande momento em que afirma a importância e o valor da sociedade civil para a contínua democratização da sociedade.

A sociedade civil para Betinho não possuía apenas o conteúdo antiautoritário ou antimilitar, ela se aplicaria de forma mais apropriada no contexto de plena democracia. Exemplo claro dessa concepção deu-se por meio da experiência do IBASE$^{18}$ que obteve a participação de centenas de associações e esferas independentes e que sobreviveram com vitalidade ao declínio do regime militar, expondo diferentes demandas para o novo contexto democrático que se desenhava no Brasil a partir da década de 1980.

Já no contexto posterior à redemocratização, o processo de decantação para se identificar o que poderia se constituir como uma "sociedade civil brasileira" não foi compreendida de forma semelhante.

O próprio Sergio Costa analisa que, o que poderia se classificar como sociedade civil brasileira, se constituía na verdade de uma colcha de retalhos, onde diversos grupos, cada qual com seus interesses, na maioria das vezes, não dialogavam entre si, pulverizando-se em distintas plataformas, podendo ser identificado por seu caráter heterogêneo e multifacetado (COSTA, 2002, p. 58 e 59).

Costa observa que, nos anos 90, as organizações da sociedade civil, por um lado, ganharam cada vez mais notoriedade e um campo específico de atuação. Associações de bairros, de mulheres, de negros exerceram significativa

${ }^{18}$ O Instituto Brasileiro de análises Sociais e Econômicas (IBASE), criado e sediado no Rio de Janeiro em 1981, por Herbert de Souza, Marcos Arruda e Carlos Afonso. Tinha o objetivo de funcionar como um instrumento de auxilio aos movimentos sociais, associações populares no sentido de promover a democratização do acesso à informação - que era percebida como a chave para o uso da cidadania plena - contribuindo também para o fortalecimento da sociedade civil. 
contribuição para o desenvolvimento e enriquecimento da esfera pública brasileira.

Por outro lado, uma das objeções feitas por Costa estava no fato de que algumas organizações, utilizando-se da categoria sociedade civil, acabariam por assumir ações e funções do Estado, ou mesmo do mercado, distanciando-se do caminho esperado a ser tomado por uma organização da sociedade civil, ora fazendo o papel que seria do Estado, acentuando ainda mais seu descrédito como promotor das mudanças, ora incorporando a crítica neoliberal, onde não apenas o governo, mas o Estado seriam percebidos como essencialmente intervencionistas e incapazes de promover o desenvolvimento (COSTA, 2002, p.58 e 59).

No entanto, para além das dificuldades analíticas e conceituais colocadas na caracterização da sociedade civil no contexto brasileiro, a perspectiva trazida por Betinho ao propor um realinhamento do Estado para a sociedade não apenas olhava para a chave da sociedade civil, mas para a força presente em todas as suas esferas.

Ainda que no caso brasileiro, autores como Costa e Weffort não constatassem uma sociedade civil homogênea e sólida - situação improvável de ser encontrada onde quer que seja. Ela existia ainda que de forma latente ou pulverizada e seria capaz de se organizar continuamente. Essa força ainda que latente, já seria para Betinho suficiente para mobilizar grandes questões a serem resolvidas no país. A simples existência de uma sociedade civil - ainda que pouco organizada - abria grandes possibilidades ao processo de democratização no país. E esse processo não partiria do Estado, tampouco do mercado, mas da força presente na sociedade (SOUZA, 1994 b).

Apesar de analisar o campo da sociedade civil no Brasil sob o prisma da ambivalência, Costa reconhece-a, entretanto, como campo majoritário de potencialidades de relações de solidariedade (COSTA, 2002, p. 60 e 61).

Junto a isto, o autor percebe a sociedade civil como um dos legítimos campos de atuação escolhidos por atores políticos que já não se identificavam com os 
partidos políticos ou com as estruturas estatais, realizando sua ação política na sociedade:

\begin{abstract}
A despeito desse conjunto de ambivalências, não me parece ser o caso de abandonar, no Brasil, a referência à sociedade civil como um campo próprio de relações sociais marcadas antes pela solidariedade que pela competição. Nesse caso, a sociedade civil compreende um contexto de ação, ao qual se vincula aquele conjunto de amplos atores que, depois do restabelecimento dos canais democráticos de expressão e do fissuramento do bloco de certa maneira unitário de oposição ao regime militar, não querem ser assimilados nem às estruturas partidárias nem ao aparelho de Estado (COSTA, 2002, p. 60 e $61)$.
\end{abstract}

Este caminho certamente traduz o destino escolhido por Betinho para escrever sua estrada no contexto da redemocratização e mesmo posterior a ele, a atuação na sociedade civil como um universo desvinculado do Estado e da política partidária como forma de melhor intervir a fim de modificá-los.

\title{
3.4. Ideia de Sociedade civil inspiradora de Betinho
}

Pode-se dizer que existe uma notável associação entre a importância crescente da sociedade civil e o contexto da redemocratização no contexto brasileiro (TONET, 2006, p.1; WOLFE, 1991, p.36). No entanto, na retomada deste conceito, para além das perspectivas analisadas anteriormente, existe uma que no entendimento deste trabalho vai ser fundamental para se constituir como diretriz conceitual a iluminar as noções e ações de Betinho após seu regresso do exílio.

Ao invés de uma concepção de mundo que olhava o desenvolvimento histórico apenas pelo prisma das classes ou do Estado, Betinho incorpora outras questões e faz sua opção pela sociedade civil (SOUZA, 1996, p.146 b).

A concepção de sociedade civil que de forma mais bem acabada poderia ser capaz de traduzir o referencial de Betinho será compreendida neste trabalho como aquela exposta por Alan Wolfe (1991), o autor abraça a ideia de que no mundo 
que surge nas últimas décadas do século $\mathrm{XX}$, já não é possível analisar o desenvolvimento das sociedades apenas pelo binômio Estado/Mercado, existindo uma terceira categoria que, cada vez mais se coloca como fundamental no desenvolvimento econômico, político e social: a de sociedade civil.

Para Wolfe, enquanto as análises sociológicas mais canônicas privilegiavam sobremaneira a economia e a política como vetores do desenvolvimento nas sociedades capitalistas modernas, deixavam de perceber uma dimensão que o autor busca trazer para complementar o Estado e o mercado. Pois, se na economia o foco mantinha-se preponderantemente no mercado, e o Estado na questão do poder, sempre na perspectiva macro, a sociedade civil permitiria pensar outros limites além das duas dimensões:

\begin{abstract}
A sociedade civil, ao contrário, requer que o foco se dirija para objetos de menor porte. Sua preocupação é com o social, mais do que com o econômico e o político. A sociedade civil tem sua atenção voltada para famílias, comunidades, organizações voluntárias, sindicatos e movimentos de base espontâneos (...). A característica fundamental da sociedade civil é que ela é flexível, disponível e aberta às pessoas comuns, à vida cotidiana. Falar da sociedade civil é reverter as prioridades da economia política. É afirmar que os seres humanos e seus desejos são capazes de alterar estruturas de outra forma determinantes (WOLFE, 1991, p. 36).
\end{abstract}

$\mathrm{Na}$ visão do autor, equilibrar a atenção entre o desenvolvimento quantitativo, medido em escala macro, e o qualitativo, compreendido na participação e na solidariedade, tornava-se fundamental para o desenvolvimento de sociedades que, como a brasileira, realizavam transição para contextos democráticos.

A impossibilidade de vivenciar experiências de ações livres na sociedade durante o período do regime militar é um elemento que ajuda a compreender como, no contexto da década de 1980, as iniciativas ao nível da sociedade ganham notoriedade, sendo percebidas com entusiasmo cada vez maior pelo fato de inexistirem anteriormente.

A sociedade civil ganha a cena também por outra motivação elencada por Wolfe: diante dos dilemas das sociedades ocidentais modernas - as democracias liberais - de fins do século XX, nem os defensores do livre mercado quando 
convidados a responder sobre a exclusão produzida pelo livre mercado, nem a esquerda estatista quando confrontada com os problemas do stalinismo soviético eram capazes de oferecer respostas satisfatórias a tais problemas.

Nesse contexto, somadas às velhas alternativas com agendas tradicionais, assim como os novos movimentos sociais que traziam demandas de novos setores, tornou-se inevitável a compreensão de que já não podia mais se dar numa chave dupla, mas numa tríade em que a sociedade civil complementava o Estado e o mercado (WOLFE, 1991, p. 42).

Sozinhos, Estado e mercado não dariam conta de organizar a sociedade no que diz respeito aos valores mais fundamentais e intangíveis como a solidariedade e a cidadania. Pensar outra dimensão que empoderasse a ação coletiva dos cidadãos, em que a democracia aparecesse como consequência da participação, aproxima a proposição de Wolfe à ação política de Betinho:

\begin{abstract}
É preciso colocar o eixo desta revolução na cidadania, em cada pessoa e em todas. Não no Estado nem no mercado. Nenhum dos dois é capaz de dar vida completa a esses princípios. Esta é uma obra do homem e da mulher, juntos. O Estado quase sempre mata ou alija um desses princípios e alega que é uma medida necessária para salvar a democracia. Mata um pedaço em nome do todo. O Estado é um animal que precisa ser sempre domesticado. Sem estar sob controle da democracia, perde o rumo. É corrompido e corrompe. O mercado sem o controle da cidadania, perde seu gosto pela liberdade e a competição. Entrega-se a uns poucos para servir a minorias (SOUZA, 1996, p.66 e 67 a).
\end{abstract}

Por isto, seria necessário transcender a esfera do universo meramente quantitativo, linguagem familiar ao Estado e ao mercado. Somente com o complemento da sociedade civil, poder-se-ia pensar num desenvolvimento com humanidade, um desenvolvimento solidamente edificado.

Wolfe conclui a análise sobre a inclusão da sociedade civil que, em seu entendimento, se constituía como vital para o desenvolvimento de um modelo de sociedade que pensasse para além do caminho intervencionista do Estado e do mercado excludente e marginalizador:

Acrescentar a perspectiva da sociedade civil à dualidade entre o mercado e o Estado cumpre essa função, ao explicitar uma abordagem que não é, nem laissez-faire, nem intervencionista (...). Os mercados e 
os Estados não esgotam o campo de possibilidades, quando o desenvolvimento entra em discussão. Nossa dualidade deve se tornar uma trindade, e a sociedade civil não pode mais ser ignorada (WOLFE, 1991, p. 61 e 63).

A descoberta da força de mobilização e organização da sociedade civil leva Betinho a agir objetivando as mudanças e a superação das desigualdades em torno das transformações na própria sociedade como primado fundamental.

Como ponto alto do entendimento de que as mudanças não viriam somente pela mão do Estado, muito menos do mercado, pode-se afirmar que se insere como objetivação empírica a ação que conferiu não apenas a maior notoriedade à biografia de Betinho, mas que marcou a sociedade brasileira na década de 1990: a Campanha da Ação da Cidadania Contra a Fome, a Miséria e Pela Vida.

\section{5. Ênfase de Betinho na sociedade civil conduzindo-o à Campanha contra a fome}

A centralidade da mudança da sociedade como caminho para as mudanças no país, pode-se dizer, constitui o eixo fundamental que caracteriza as ideias de Betinho a partir de seu retorno do exílio. Junto a ela, encontra-se um resguardo contínuo com relação ao Estado, do qual Betinho busca se afastar. Em artigo escrito em 1994, no contexto do calor das eleições presidenciais, Betinho afirma:

\footnotetext{
Começo por dizer que não creio que o governo seja o fundamental em nenhuma sociedade e muito menos numa sociedade como a nossa. $\mathrm{O}$ poder do governo é sempre o poder dominante de uma sociedade. Sem mudar a sociedade não adianta mudar o governo. A mudança é aparente, é uma armadilha, é uma mentira. Por isso, meu olhar e minha atenção estão concentrados sobre a sociedade (SOUZA, 1994, p.1 b).
}

Tais palavras proferidas por Betinho às portas das eleições gerais de 1994 explicitam de forma categórica como o centro das atenções de Betinho se 
encontrava distante da política partidária/eleitoral para estabelecer sua ação política na sociedade.

Para ele, a chave das mudanças no Brasil encontrava-se no primado da mudança da sociedade. Não adiantaria tomar posse do Estado logrando mudar a partir dele sem a sociedade. O caminho era, inevitavelmente, inverso.

Na concepção de Betinho, o Estado poderia ser considerado como uma espécie de epifenômeno da sociedade, por isso fazia mais sentido mudar a sociedade, pois era a partir dela que se mudaria essencialmente o Estado. Ao invés de mudar o Estado por ele mesmo, como pensava até o exílio, agora a mudança do Estado tem como itinerário imprescindível a mudança da sociedade:

\begin{abstract}
A organização centralista do poder do Estado brasileiro responde à organização centralista da sociedade e existe para garanti-la (...). O estatismo brasileiro não revela um amor especial das classes dominantes por um tipo de concepção política, mas uma necessidade política concreta de proteger o poder da minoria contra a maioria (...). $\mathrm{O}$ Estado é o retrato da sociedade. Uma sociedade conservadora não produz um retrato liberal (SOUZA, 1987, p. 40 e 41).
\end{abstract}

Nesse sentido, o eixo das mudanças encontrava-se na relação Estado-sociedade, cuja característica histórica brasileira deveria dar um giro de 180 graus, tornando o Estado uma organização à serviço da sociedade. Para isto, tornava-se necessário que a sociedade descobrisse sua força, sua capacidade de organização e sua centralidade em relação ao Estado.

A descrença em relação ao Estado aumenta quando na relação direta do amadurecimento da convicção de que, na sociedade civil, se encontrava a chave para impulsionar um processo de mudança nas estruturas sociais. As urgentes mudanças que se faziam necessárias, o enfrentamento das históricas desigualdades de renda, de acesso à terra, de gênero, não seriam, satisfatoriamente, enfrentadas apenas pelas iniciativas do Estado, mas pelo engajamento da sociedade a pressioná-lo.

A novidade trazida por Betinho é a defesa da percepção não apenas da anterioridade, mas da primazia da sociedade sobre o Estado. Era necessário que a sociedade descobrisse sua força em relação ao Estado. As mudanças fundamentais 
adviriam a partir da submissão do Estado à sociedade. O Estado deveria ser pensado como um servente da sociedade. Era ela que, para Betinho, reunia as condições necessárias para se forjar um Estado fundamentalmente democrático:

\begin{abstract}
A sociedade civil é primeira, é fundadora; o Estado é resultado, é produto. Fixar-se no Estado em detrimento da sociedade civil é perpetuar a concepção autoritária de sociedade e Estado, e mais grave ainda, é tomar como ponto de partida a ordem política estabelecida pelos interesses dominantes das classes dominantes. A constituição liberal ou democrática deve partir da sociedade e não do Estado; dos direitos sociais dos trabalhadores e não das prerrogativas e poderes do ministério do trabalho; dos instrumentos e mecanismos de controle do Estado por parte dos cidadãos e não da submissão do cidadão e da sociedade ao Estado (SOUZA, 1987, p. 44).
\end{abstract}

Nesse sentido, o fundamento de seu engajamento, a partir da década de 1980, concentra-se na militância na sociedade civil, acreditando na força dessa dimensão muitas vezes minimizada.

Um projeto de país que se propusesse a enfrentar seus problemas fundamentais não poderia continuar sendo estruturado apenas sob o eixo da política partidária, que sozinha já não reunia tais condições de mobilização. Pois, na percepção de Betinho, os partidos já não conseguiam mais responder às demandas da sociedade por se encontrarem ocupados demais com os meandros das estruturas estatais. O meio acabou transformando-se no fim da atuação político-eleitoral.

\begin{abstract}
Por isso mesmo é que nos últimos anos o Estado tomou conta de todos os aspectos da vida dos partidos dentro do mais absoluto controle e vigilância. A criatura controlou e aprisionou o criador, o Estado estatizou e a sociedade civil não civilizou os partidos (...). A sociedade democrática que se aspira necessita libertar os partidos totalmente da tutela do Estado para que o Estado possa ser submetido à sociedade civil e a democracia possa existir (SOUZA, 1987, p. 50).
\end{abstract}

Percebe-se a importância e a genialidade das objeções de Betinho que identificava, já na década de 1980, um problema ainda muito presente no Brasil de hoje. A perda da capacidade de sintonia da política partidária com o conjunto da sociedade já era identificada por Betinho e apresentada com uma conformação propositiva da inclusão da sociedade nas estruturas de poder do país. 
O engajamento no processo de reconstrução democrática do país constituiu uma das bandeiras na qual Betinho organizou sua militância. Em momento algum, ela confundiu-se com a militância partidária, da qual Betinho fez questão de se separar, de tirar do horizonte de suas perspectivas.

Apesar de constante e inevitavelmente ser assediado pelo brizolismo, por toda sua histórica ligação com Brizola ${ }^{19}$ desde os tempos do golpe e do exílio e, por outro, pelo $\mathrm{PT}^{20}$ que agregava naquele momento uma série de notáveis figuras comprometidas com a transformação da sociedade, dentre os quais seu próprio irmão Henfil, Betinho não se filiou a nenhum partido (RODRIGUES, 2007, p.195 e 196).

Podemos dizer que Betinho escolheu seu próprio partido, o partido do engajamento com a sociedade. Uma atuação política à margem do caminho eleitoral, por fora das estruturas burocratizadas do Estado.

Esta opção se materializou também em função da certeza de que, cada vez mais transparecia a Betinho, a sociedade tinha dentro de si uma força que, de alguma maneira, se encontrava em estado de latência, mas, no entanto, precisava ser mobilizada e aguçada.

Era no interior das instituições e das dinâmicas da sociedade - diferente de décadas atrás quando o mesmo buscaria na transformação do Estado a emergência de uma nova sociedade - que nasceriam as propostas e ações concretas. A democracia poderia até ser garantida pelo Estado, mas nasceria inevitavelmente do seio da sociedade:

O que acho que está surgindo, sempre existiu, mas que está numa nova onda no mundo, é a onda democrática. Eu acho que ela não se dá, é uma onda que não se manifesta a nível essencialmente do

\footnotetext{
${ }^{19}$ Leonel de Moura Brizola (1922-2004), importante político brasileiro. Ligado às origens do trabalhismo iniciou a carreira política e lançado na vida pública por Getulio Vargas, foi deputado estadual e federal pelo Rio Grande do Sul, prefeito de Porto Alegre e governador do Rio Grande do Sul, quando liderou a chamada "Rede da legalidade" em apoio à posse legítima do então vice presidente da República João Goulart. No retorno do exílio ajudou a fundar o PDT, sigla em que elegeu-se governador do Rio de Janeiro por duas ocasiões.

${ }^{20}$ Partido fundado em 1980, a partir da influência de intelectuais, sindicalistas, movimentos de esquerda e das comunidades religiosas progressistas, que buscavam criar um partido que encampasse a luta e as demandas comuns aos trabalhadores brasileiros.
} 
Estado, do poder, mas ela se manifesta a nível dos movimentos sociais (SOUZA, 1996, p. 127 b).

O desenvolvimento deste conjunto de concepções que passou a associar a chave da transformação da estrutura social a instâncias da sociedade constitui orientações que, na prática, vão se materializar na experiência de Betinho no IBASE e, sobretudo, na experiência da Campanha da Ação da Cidadania que se fundou na sociedade, no engajamento da sociedade e na negação do caminho eleitoral pelas vias da instituição do Estado.

\subsection{Prática cidadã como valor na experiência de Betinho}

O conjunto das estratégias de ação política desenvolvidas por Betinho no contexto de seu retorno do exílio revelam também a exposição de um valor fundamental que pautou a militância de Betinho: o conceito de cidadania como valor como fundamento inexorável para a edificação de uma plena democracia, ou em seus termos, de uma democracia radicalizada.

Junto ao valor da democracia e a importância da sociedade civil, que constituem-se como diretrizes da ação de Betinho sobretudo no contexto de seu retorno do exílio, aparece em seu horizonte um aspecto fundamental para pensar sua ação: a cidadania como elemento que confere o principal fundamento da democracia reivindicada por Betinho.

A democracia em sua forma radical, prescindia inexoravelmente de uma prática cidadã, desenvolvida em todas as esferas da sociedade, desde as mais simples e cotidianas às maiores e mais importantes. Vivenciar o contexto de uma participação constantemente ativa e cidadã constituía o cimento social que poderia edificar a uma nova organização social e política que efetivasse os valores de igualdade, liberdade e participação reivindicados por Betinho. 
Nesse sentido, não apenas a experiência da Campanha da Ação da Cidadania surge como elemento que confere contornos sólidos a estas compreensões, mas também as próprias experiências e realizações de Betinho no contexto da década de 1980, já afirmavam o sentido da importância da edificação da democracia a partir do primado da experiência da cidadania.

No próprio contexto dos anos 80 , em que a sociedade brasileira experimentava um complexo contexto de mudanças nas mais diversas áreas, quando se tinha no horizonte o contexto das lutas pela superação da ditadura e, junto a elas o contexto de organização dos partidos políticos, da luta pela efetivação das eleições diretas, Betinho já mostra-se como pioneiro ao propor - ao invés do engajamento num partido político - a criação de uma organização não governamental como um dos principais instrumentos de intervenção na sociedade.

A criação do IBASE, nesse sentido representou um importante indicativo da direção que Betinho toma no retorno do exílio: a militância no contexto da sociedade. O IBASE, que tinha como um de seus pilares, a criação de condições, por meio do melhor acesso à informações, para o suporte e organização dos movimentos sociais, teve importância fundamental no processo de animação das lutas sociais.

Betinho, foi um dos personagens que mais contribuiu, no contexto do desenvolvimento do que hoje classificamos de ONG, não apenas pelo que representou o IBASE para o desenvolvimento das não governamentais no Brasil, mas também por sua própria biografia refletir em vários e diferentes estágios, o processo de desenvolvimentos das ONGs, como o início na militância religiosa, a posterior separação da esfera da igreja e o desenvolvimento de uma luta contra a miséria secularizada (LIMA NETO, 2013).

A "veia" da experiência cidadã em Betinho, estava colocada também num aspecto fundamental de sua trajetória: a AIDS. No contexto desta mesma década, quando o vírus HIV, torna-se um problema de dimensões globais, Betinho consegue transformar um drama pessoal e familiar - uma vez que ele e seus dois irmão hemofílicos contraem o vírus - em mais um motivo para empunhar uma 
bandeira de lutas por um melhor e mais adequado tratamento do Estado aos pacientes soropositivos.

Nesse sentido, a criação da ABIA, representou também um elemento que ajuda a observar como a partir do exílio, todas as ações de Betinho tem como fundamento a luta pela edificação da experiência cidadã, que era percebida como principal pilar para o desenvolvimento da democracia.

Apesar de tornarem-se mais claras no contexto do retorno do exílio, a prática cidadã como aspecto central da concepção de democracia de Betinho é algo verificado desde sua militância de juventude, que no entanto, ganham papel mais central no contexto de suas lutas desenvolvidas nas décadas de 1980 e a Campanha da Ação da Cidadania, onde a experiência da ação cidadã como valor é observada como o caminho para um outro tipo de estrutura social.

\subsection{Experiência da campanha da Ação da Cidadania Contra a Fome, a Miséria e Pela Vida}

\subsubsection{A campanha como primeiro passo de uma longa jornada}

Como observado no decorrer deste trabalho, ao longo da experiência de Betinho se desenvolve o entendimento sobre a sociedade, no qual ela é percebida como empoderada e gabaritada para se constituir como vanguarda no processo de mudanças.

Apesar de as motivações mais fundamentais da campanha já estarem em Betinho desde o retorno ao exílio e o tema da fome já constituir, na mesma época, uma preocupação sua, é apenas no contexto do fim da década de 1980 e início dos anos 90 que as intenções de Betinho encontram as condições reais para sua realização (PANDOLFI; HEYMANN, 2005, p. 179). 
A Campanha da Ação da Cidadania nasce no contexto do início da década de 1990, originada a partir do Movimento Pela Ética na Política ${ }^{21}$, que teve como expressão maior a mobilização em torno da defesa do impeachment do presidente Fernando Collor em 1992 (LANDIM, 1998, p.243).

Conquistado o objetivo inicial: o impeachment, o movimento, para não encerrar suas atividades, buscou empunhar a defesa de outros temas e questões éticas no Brasil. Neste momento, tendo como base um relatório divulgado pelo Instituto de Pesquisas Econômica Aplicada (IPEA), conhecido como Mapa da fome ${ }^{22}$, mobilizaram-se em torno da defesa da causa, um problema nacional que se constituía de forma escandalosa, mas silenciosamente, a fome de 32 milhões de pessoas num país rico. A intenção era novamente chamar atenção da sociedade a indignar-se e a mobilizar-se por mais uma causa (PANDOLFI e HEYMANN, 2005, p.180; PLASENCIA, 1998, p. 60).

A campanha do impeachment, sua amplitude e sucesso, solidificaram, em Betinho e nas entidades que compunham o Movimento pela Ética na Política, a ideia de que havia na sociedade uma força simpática à transformação que necessitava ser estimulada cada vez mais. A Campanha da Ação da Cidadania nasce no contexto do Movimento pela Ética na Política, com o intuito de não abandonar a força de mobilização da sociedade:

\begin{abstract}
Quando o impeachment terminou, percebemos que havia nascido um movimento na sociedade. Não foram as lideranças políticas que tiraram o Collor, foi a sociedade brasileira que depôs o presidente. Aí o pessoal do Movimento pela Ética na Política se reuniu de novo. Estávamos todos surpresos com a força do movimento, uma força que claro, não era nossa, mas da sociedade (...). Nós dizíamos: “puxa, essa sociedade é mesmo muito forte. O que vamos propor agora, qual é a nova ideia?" (SOUZA, 1994, p. 57 f).
\end{abstract}

\footnotetext{
${ }^{21}$ Movimento Pela Ética na Política, criado e desenvolvido por instituições da sociedade civil, igreja, entidades sindicais que reuniram-se no inicio da década de 1990, buscando conferir um sentido ético à política. Este movimento esteve na vanguarda das lutas pelo impeachment do presidente Fernando Collor. Terminada a campanha pelo impeachment, após sua deposição, as entidades que a compunham buscaram uma nova causa ética em torno da qual pudessem continuar a mobilizar-se. Desse novo esforço redundou a Campanha da Ação da Cidadania.

22 "O mapa da fome: informações sobre a indigência por município da federação", estudo organizado e publicado pelo IPEA, sob a coordenação da socióloga Anna Peliano, que forneceu um amplo leque de informações sobre a pobreza no Brasil, ajudando a dimensionar e quantificar o problema da fome e da insegurança alimentar a nível nacional.
} 
A Campanha da Ação da Cidadania Contra a Fome, a Miséria e Pela Vida é então lançada no dia 08 de março de 1993 pelas mesmas entidades que haviam integrado o Movimento pela Ética na Política. Sua diretriz fundamental consistia na defesa da incompatibilidade entre miséria e democracia. Era inconcebível aceitar passivamente que um dos países com maior PIB do mundo coexistisse com a miséria e a exclusão social. No evento de lançamento, foi divulgada uma carta intitulada, "Carta da Ação da Cidadania", que continha as ideias básicas do movimento (PANDOLFI e HEYMANN, 2005, p. 180).

Transcrito a seguir o conteúdo da carta que resume, de forma clara e direta, as pretensões da Campanha:

"Chegou a hora de colocar um basta nesse processo insensato e genocida gerador da miséria absoluta que coloca milhões de pessoas nos limites insuportáveis da fome e do desespero. Não podemos aceitar que seu drama será resolvido após a realização de um programa de estabilização da economia que criaria as condições para amenizar a crise social que parece existir por conta própria. O tempo da miséria absoluta e da resignação com esse quadro acabou. A sociedade brasileira definiu a erradicação da miséria como sua prioridade absoluta. Esse é o clamor ético de nossos tempos ao qual tudo mais deve se subordinar. Essa deve ser a prioridade da sociedade e do Estado. Essa é a obrigação de cada um e de todos Do governo federal e do congresso. Dos governos estaduais e municipais. Das entidades da sociedade civil. Dos trabalhadores e dos empresários. Esse é hoje, o grande divisor de água entre nós: entre os que querem erradicar a miséria ainda nessa geração e os que insistem em ficar indiferentes diante de uma tragédia que ameaça nossa própria existência como nação e como humanidade. Tudo deve responder a essa questão. $\mathrm{O}$ orçamento público, as políticas, as ações governamentais e não governamentais, as atividades produtivas, comerciais e financeiras, as atividades de ensino, pesquisa, promoção social e cultural, em que medida dão prioridade dessa questão? Ou em que medida ajudam a aprofundar esse fosso que nos separa e nos divide entre os que tem e os que vivem na mais profunda miséria?. Não se pode viver em paz em situação de guerra. Não se pode comer tranquilo em meio a fome generalizada. Não se pode ser feliz num país onde milhares se batem no desespero do desemprego, da falta das condições mais elementares de saúde, educação, habitação e saneamento Não se pode fechar a porta à consciência, nem tapar os ouvidos ao clamor que se levanta de todos os lados. A insanidade de um país que marginalizou a maioria deve terminar agora. $\mathrm{O}$ modelo de desenvolvimento que produziu a miséria está condenado. Por isso, nós abaixo assinados declaramos que essa é nossa prioridade e o nosso apelo. O Brasil precisa mobilizar todas as suas energia para mudar de rumo e colocar um fim a miséria. Deve criar em todos os lugares e com a participação de todas as pessoas a Ação da Cidadania em luta contra a miséria e pela vida. Conclamamos a todos a construir esse movimento. Podemos ainda produzir o encontro do Brasil com sua própria sociedade. Democracia e miséria não são compatíveis. Que 1993 seja um ano de mudança de rumo de nossa história a partir da 
ação de cada um, da Ação da Cidadania (AÇÃO DA CIDADANIA, Apud PANDOLFI; GAZIR; CORREA, 2012, p. 164 ).

Além disso, a Campanha baseava-se na ideia de que o primeiro passo deveria ser dado por iniciativa da própria sociedade. Ficar esperando que as instituições estatais resolvessem o problema seria inútil num país cujo Estado sempre existira para garantir os interesses dos grupos que se beneficiavam das desigualdades. Seria necessário que a própria sociedade agisse. Não apenas o engajamento político, mas o sentido ético de solidariedade (princípio da democracia para Betinho) constituía o norte da campanha:

Como nasce a Ação da Cidadania? Ela nasceu do Movimento Pela Ética na Política. Foi o mesmo grupo que participou do Movimento Pela Ética que fez uma reunião (...) e disse: ‘democracia e miséria são incompatíveis. Então a luta principal é contra a miséria. Qual é a expressão maior da miséria hoje no Brasil? É a fome. Tem 32 ou 26 milhões de pessoas com fome que não podem esperar. Trata-se de alimentar essa população. Esta é uma responsabilidade do poder público e da sociedade também, porque a sociedade não vai ficar esperando o poder público, porque afinal foi ele, ao longo desse tempo, que produziu essa miséria toda. Você não vai querer que imediatamente o criador abandone a criatura (SOUZA, 1996, p.164 b).

A Campanha teria como objetivo mais urgente doar alimentos aos que necessitavam. Sob o inconfundível lema que imortalizou a figura de Betinho, "quem tem fome tem pressa", a ideia inicial era, sem uma estrutura hierárquica vertical, aproximar aqueles que precisavam receber daqueles que estavam dispostos a ajudar:

A Ação da cidadania pautava-se por três princípios: parceria, iniciativa e participação. De forma simples, Betinho assim os caracterizava: parceria porque propõe juntar quem quer com quem precisa receber. Iniciativa porque não apresenta respostas, mas coloca questões e cobra soluções. Descentralização porque não estabelece um modelo hierárquico, mas sim estimula ações sem impor uma coordenação (PANDOLFI; HEYMANN, 2005, p. 181). 
A Campanha, apesar de vislumbrar a mudança da estrutura social brasileira, obteve sucesso muito em função do seu objetivo mais premente e simples. Não se necessitava de aparatos, organizações ou coisas do tipo, apenas a disposição e boa vontade de ajudar, "de fazer alguma coisa". Portanto, era necessário estimular cada pessoa que estivesse disposta a ajudar, a partir do que estava ao seu alcance (RODRIGUES, 2007, p. 203).

Este princípio organizacional presente na constituição da Campanha não foi constituído aleatoriamente. Ele pode ser explicado com base na própria revisão da trajetória de Betinho, conforme observado no capítulo anterior, em que a busca pela superação das estruturas de partidos e organizações rígidas, cede lugar a uma concepção mais independente destas organizações.

\subsubsection{Chamamento ético-politico}

A Campanha Contra a Fome constitui a busca de Herbert de Souza pela retomada de sua ação política, buscando diferenciar-se de suas experiências passadas. Ela é fruto de uma tentativa muito mais audaciosa de expressão, de uma nova forma de ação política que partia de um elemento não usual, de uma forma de organização pouco comum, que se propunha, no entanto, a atacar os mesmos elementos que algumas ações políticas tradicionais buscavam, a desigualdade e exclusão.

O discurso da Campanha partia de um argumento ético e humano e aprofundava-se pelo político. Era a partir do primeiro ato, da doação de alimentos, da recusa à internalização passiva da miséria como algo natural, da mobilização, ainda que pequena, que se partiria para atacar a miséria e a desigualdade em sua expressão estrutural.

Por isso, para o movimento da Ação da Cidadania acabar com a fome e a miséria não se limitava a dar comida e gerar emprego. Supunha começar por incorporar 32 milhões de seres humanos no mapa da cidadania, reconstruir radicalmente toda a sociedade, unindo as forças, as vontades e esperança para encontrar novos caminhos para um desenvolvimento mais humano, solidário e ético para o Brasil (...). O 
convite era para todos. Constituía um apelo para assumir o compromisso radical de assumir a questão da fome e da miséria numa questão a ser resolvida por cada um, num problema a ser resolvido por todos, solidariamente e de forma concreta. Um apelo a tudo que a cidadania tem de fraterno, solidário, de indignação (PLASENCIA, 1998, p. 66).

Surgia o compromisso ético-político como farol a iluminar a utopia de Betinho em sua ação política de contestação do indigno quadro de desigualdade na estrutura social brasileira. Este chamamento transcendia o caráter classista de sua militância de outrora. Apesar de não negar a existência da estratificação e organização classista da sociedade brasileira, Betinho organizou a adesão à campanha a partir de um argumento que, mais que político, é humano: da fome como a expressão máxima de marginalização.

Em artigo publicado sobre o tema, Betinho expôs seu pensamento de forma clara e direta, observando que a fome constituía a expressão máxima da exclusão. A existência da fome indicava que a sociedade já havia negado tudo aos famintos. Nesse sentido, lutar contra a fome consistia em lutar contra todas as injustiças e exclusões que se abatiam sobre as vítimas:

\begin{abstract}
A fome é exclusão. Da terra, da renda, do emprego, do salário, da educação, da economia, da vida e da cidadania. Quando uma pessoa chega a não ter o que comer, é porque tudo o mais já lhe foi negado. É uma espécie de cerceamento moderno ou de exílio. A morte em vida. E exílio da terra. A alma da fome é política (SOUZA, 1994, p. 22 a).
\end{abstract}

Esse complexo movimento de reversão das profundas disparidades começaria, entretanto, com ações relativamente simples. Era a partir do simples que se partiria para o complexo, do empírico para o teórico, do emergencial para o estrutural. Era a partir da força da solidariedade como paradigma norteador que a campanha buscou se expressar.

A compreensão de que os processos de mudança exigiam muito mais o contato direto da sociedade com suas mazelas que o processo teórico de conscientização direcionou o mote da campanha. O passo inicial da mudança encontrava-se acessível aos brasileiros, ao cidadão comum: 
Por isso, o gesto de solidariedade, por menor que seja, é tão importante. É um primeiro movimento no sentido oposto a tudo que se produziu até agora. Uma mudança de paradigma, de norte, de eixo, o começo de algo totalmente diferente (...). Se a exclusão produziu a miséria, a solidariedade destruirá a produção da miséria, produzirá a cidadania plena, geral e irrestrita. Democrática (SOUZA, 1994, p. 24 a).

E Betinho sinceramente acreditava que havia na sociedade brasileira uma disposição latente para a ação que visava contribuir para superar os vergonhosos índices de miséria e desigualdade.

A mesma força presente na disposição de luta contra a ditadura militar, a mesma disposição observada nas campanhas de redemocratização dos anos 80, no impeachment do presidente no ano anterior, encontrava-se silenciosa na sociedade brasileira. Para Betinho, era necessário chamar a sociedade para a mobilização.

Foi neste espaço, neste vácuo que a Campanha buscou chamar atenção para sua agenda:

\begin{abstract}
Quando o movimento da Ação da Cidadania começou, ninguém esperava que fosse capaz de andar tão rápido, de se expandir com tanta força, de tocar tantas e tão diferentes pessoas, de encher auditórios e de se espalhar por todos os cantos do país. Há uma tremenda força de mudança no ar, na terra. Há um movimento poderoso, tecendo a novidade através de milhares de gestos de encontro. Há fome de humanidade entre nós, por sorte ou por virtude de um povo que ainda é capaz de sentir, de mudar e de impedir que se consume o desastre, o suicídio social de um país chamado Brasil (SOUZA, 1994, p. 25 a).
\end{abstract}

A campanha mostrou ser muito bem sucedida em seu discurso que se, no momento do impeachment opunha ética à corrupção, agora opunha ética à miséria. A estrutura deste discurso, tal como a campanha do impeachment foi novamente abraçada pela sociedade brasileira.

\title{
3.7.3. Abrangência, organização e adesão
}

A Campanha da Ação da Cidadania constitui na história recente do país um dos mais importantes movimentos, não apenas por seu aspecto qualitativo, como 
observado até aqui, mas também por sua amplitude numérica. $\mathrm{O}$ movimento alcançou dimensões inéditas em nossa história.

Para se ter ideia da amplitude alcançada pela campanha, podemos notar que uma pesquisa realizada pelo IBOPE, em dezembro de 1993, revelou que, nada menos que sessenta e oito por cento $(68 \%)$ da população já conhecia ou tinha ouvido falar sobre a Campanha. Desses, trinta e dois por cento (32\%), cerca de 26 milhões de pessoas, afirmava haver, de alguma forma, participado ou contribuído com a Campanha (SOUZA, 1996 b, p. 165; LANDIM, 1998, p.242; LIMA NETO, 2013, p.71; RODRIGUES, 2007, p. 211).

Além disso, dentre os 26 milhões de pessoas que afirmavam já ter contribuído com a Campanha, onze por cento (11\%), cerca de 2,8 milhões, afirmava pertencer a algum Comitê de Combate à Fome, unidade básica de organização da Campanha (LANDIM, 1998, p. 242).

A partir dessas informações, podemos perceber que, somente nos comitês criados de forma independente e descentralizada pelos que tinham vontade de ajudar, quase três milhões de pessoas organizavam-se ativamente na Campanha. Esses números certamente invejam qualquer partido ou organização que teria dificuldades para mobilizar uma fração da população nesta proporção.

Quando pensado sob a perspectiva histórica da amplitude numérica do engajamento da sociedade em movimentos formais e institucionais, o alcance da Campanha torna-se ainda mais notável, como observa Landim:

Considerando-se os baixos índices de participação institucional da população brasileira, ou mesmo a propalada cultura política estatizante predominante nesse contexto - ou ainda a discutida crise dos movimentos sociais e ideologias - esses números relativos a uma ação voluntária, com algum grau de organização, no âmbito da sociedade são extremamente elevados e dão o que pensar (LANDIM, 1998, p. 242 e 243).

Estes números solidificam a compreensão de que, inexoravelmente, havia uma predisposição da sociedade em agir de alguma maneira para contrapor o quadro de miséria e desigualdade presente no Brasil. Nenhuma empreitada é alçada a tais dimensões sem o apoio de amplos setores da sociedade. 
A extraordinária recepção da Campanha por parte da população funcionou também como um contraponto silencioso aos críticos dela, sobretudo, os do campo da esquerda que faziam, como observo no capítulo seguinte, inúmeras objeções e frequentemente associando a Campanha a eventos de cunho assistencial.

Essas vozes tiveram que se calar frente à enorme adesão da sociedade e também à perspicácia do uso do discurso por parte de Betinho, pois ninguém teria coragem de se pronunciar de forma contrária a uma Campanha que se propunha acabar com a fome (RODRIGUES, 2007, p. 211).

Diante dessas críticas, Betinho observava:

E todo mundo vinha em cima: 'isso é assistencialismo, você está acabando com a revolução, e o socialismo? E a questão estrutural?' (...). Eu tentava responder às críticas dizendo o seguinte: 'quem tem fome tem pressa, não dá pra esperar a mudança estrutural. Mas, eu sei que só com mudanças estruturais políticas e econômicas é que a questão se resolve mesmo (SOUZA, 1996, p.166 b).

As críticas vindas do campo da esquerda muitas vezes eram as mais contundentes a Betinho e à Campanha. No capítulo seguinte, será explorada, com maior profundidade, a distinção feita entre solidariedade e assistencialismo, feita por Betinho, em resposta a tais críticas.

Tal alcance estratosférico da Campanha, é preciso notar, foi conseguido muito em função do apoio dado pela imprensa e pela grande mídia que chegou a veicular gratuitamente, nas redes nacionais de televisão, como a Rede Globo e a TV Bandeirantes, propagandas da Campanha conferindo a Betinho e à Campanha, de maneira geral, um relativo espaço nas mídias. A TVE foi além, chegando a promover um dia inteiro de programação dedicada à Campanha (SOUZA, 1996, p. 165 b; RODRIGUES, 2007, p. 209 e 210).

Junto a isto, a adesão de publicitários que contribuíram com produções, tanto das inserções na televisão, quanto na produção de marcas e slogans para a Campanha foi fundamental para seu processo de publicização, que atingiu os níveis já mostrados aqui (RODRIGUES, 2007, p. 207 e 209). 
Outro aspecto fundamental que contribuiu para o alcance da abrangência da Campanha foi a adesão de artistas, que a impulsionou. Esse apoio culminou, inclusive, na realização de um grande evento que marcou a expressiva adesão de artistas, conhecido como a "Semana de Arte contra a Fome", realizado em setembro de 1993. Nesta semana da arte contra a fome, o evento principal organizado no Teatro Municipal do Rio de Janeiro contou com a participação de mais de cem artistas, como Fernanda Montenegro e Grande Otelo. Estiveram em cartaz uma série de espetáculos em cujas sessões era cobrado um quilo de alimento como entrada (RODRIGUES, 2007, p. 210).

Outro capítulo que merece ser notado no que se refere ao alcance da Campanha foi a participação das presidiárias da penitenciária feminina Talavera Bruce, no Rio de Janeiro, que, como forma de incorporação à Campanha, internalizando o espírito do discurso de Betinho cuja afirmação era de que todos, independentemente de sua condição, podiam ajudar de alguma forma, deixaram de jantar uma vez por semana, doando a quantidade de alimentos economizada para a Campanha, levando também a ideia para outros nove presídios:

\begin{abstract}
A mais impressionante das manifestações de apoio saiu, no entanto, da inusitada iniciativa das detentas do presídio Talavera Bruce. Foi idéia dessas mulheres presas mobilizar cerca de 4.500 internos em nove presídios diferentes no Rio e doar para os comitês da Campanha as refeições a que têm direito. Foram 2,5 toneladas de alimentos que garantiram a alimentação de duzentas famílias por duas semanas de novembro no ano passado (SOUZA, 1994, p. 61 e 62 e).
\end{abstract}

Betinho, posteriormente, chegou a visitar o presídio para conhecer aquelas mulheres que, mesmo na condição de presidiárias, encontraram uma forma de ser solidárias, recebendo-o como um ídolo calorosamente (RODRIGUES, 2007, p. 211).

\title{
3.7.4. Incompatibilidade entre democracia e miséria
}

O processo de compreensão sobre a incompatibilidade entre democracia - ainda que com todas as suas limitações - e miséria constituía uma das bases em que o discurso da campanha estava ancorado. Não se poderia continuar a aceitar de 
forma passiva a ideia de que a miséria era presença inevitável numa sociedade que se pretendia democrática. A miséria, no discurso de publicização da campanha, ultrajava a democracia e a própria sociedade, constituindo um crime cujos cúmplices eram todos os que insistiam em ignorá-la. Era um crime cometido pela sociedade que precisava ser interrompido:

\begin{abstract}
Miséria é imoral. Pobreza é imoral. Talvez seja o maior crime moral que uma sociedade possa cometer. Colocar pessoas na indigência e admitir o absurdo de uma minoria milionária, esbanjadora e indiferente ao lado de milhões e milhões de indivíduos que não têm o que comer (SOUZA, 1994, p. 57 f).
\end{abstract}

Para além da defesa do argumento ético-moral, Betinho propôs, no decorrer da Campanha, desenvolver o argumento de que uma sociedade que se almejasse democrática não poderia aceitar conviver passivamente com a miséria de parte de sua população. A ideia era a de que, para existir, a democracia precisaria ser universal, isto é, para todos sob pena do esfacelamento do próprio tecido social. Não era possível, nem admissível para um país que figurava entre as 10 maiores economias do mundo, conviver com a miséria de 32 milhões de pessoas:

\begin{abstract}
A esta altura da humanidade é incrível que isso aconteça. Como morrer de fome ao lado de 70 milhões de toneladas de grãos, de 8,5 milhões de hectares de terra, se todos esses brasileiros miseráveis ficariam saciados só com $20 \%$ do desperdício? Pela fome de 32 milhões se revela a essência humana do próprio país, aquele que é capaz de negar a condição humana para $20 \%$ de sua população. A fome é o atestado de miséria absoluta e o grito de alarme que sinaliza o desastre social de um país, que mostra a cara do Brasil (SOUZA, 1994, p. 23 a).
\end{abstract}

A exploração do argumento dessa incompatibilidade constituiu-se num dos pilares sobre os quais a Campanha estruturou seu discurso mais fundamental. Ela era, antes de mais nada, uma convocação para que as pessoas refletissem sobre que tipo de sociedade, de democracia era aquela que conseguia a proeza de coexistir junto à miséria. 
Um dos mais importantes legados da Campanha pode ser observado no convite ao estranhamento da coexistência da exclusão com a democracia. Se convencendo de que não seria digno de ser rotulado como democrático um país que:

(...) exclui, que não se organiza para propiciar trabalho, emprego, renda para todos, não é ético; é perverso. Uma economia que não integra todas as pessoas não é ética. Uma sociedade que só oferece possibilidades de trabalho normal, regular, remunerado para uma minoria e que deixa a maioria à margem, à mingua, não é democrática; é imoral (SOUZA, 1994, p. 40 c).

Esta proposta de incompatibilidade marcou não apenas a Campanha, mas a própria trajetória de Betinho nos seus últimos anos de vida. Esta bandeira, muitas vezes ignorada pelas vozes dos que lhe faziam objeções, constitui um de seus elementos mais fundamentais. A ênfase no questionamento da desigual estrutura social brasileira marcou sobremaneira a campanha, fato que a tornava maior e mais abrangente que uma simples Campanha de doação de alimentos.

\subsection{Campanha como momento de aposta na sociedade}

A adoção de uma nova diretriz que orientava as visões de mundo de Betinho que, como observado neste trabalho, ganharam corpo a partir da década de 1970, traduz-se em seu regresso ao Brasil numa tentativa de transformação do Estado pela via da participação da sociedade civil como elemento impulsionador de sua democratização. Só fazia sentido transformar o Estado se fosse com e por meio da sociedade.

A sociedade era compreendida por Betinho como a esfera de onde se criariam os mecanismos mais concretos de modificação da estrutura social brasileira. Esta escolha confirmava-se cada vez mais à medida que era comparada à realidade social brasileira que, na década de 1980, vivia um de seus momentos mais efervescentes de recrudescimento da força da juventude, dos movimentos sociais e dos sindicatos que demandavam maiores avanços. 
Se o reino da política partidária se encontrava mais alinhado às preocupações dos militares que desejavam realizar uma transição "dentro da ordem", era necessário encontrar outra plataforma de lutas que refletisse os desejos da sociedade, que estavam muito distantes tanto dos militares, quanto da política partidária.

Mesmo após a redemocratização, já no contexto dos anos 90, era possível notar que a mesma força que estivera presente nas ruas pedindo o fim da ditadura e das eleições diretas se fazia presente na campanha pelo impeachment do presidente Collor (RODRIGUES, 2007, p. 198).

É no contexto de um movimento de esperança na força da sociedade que a Campanha da Ação da Cidadania pode ser melhor compreendida. Ela constitui a expressão da busca pelo engajamento político, de indignação com a fome e a miséria num país rico. Ela é a expressão política de negação do status quo da estrutura social à margem das vias institucionais e partidárias.

Ela constitui a busca pela ação, que se inicia pelo que está ao alcance de todos como forma de abrir caminho para o que não está e como forma também de chamar atenção do próprio Estado, que insistia em ignorar ou não responder com devida atenção aos problemas daquela sociedade, para refletir sobre o sentido mais fundamental da Campanha como pontapé inicial para a mudança, não apenas esperar pelos outros.

Passados vinte anos, pensar a Ação da Cidadania hoje é fazer um acerto de contas com seu legado, retratando-a a partir de sua natureza mais fundamental, que ultrapassa a forma como ela ficou majoritariamente compreendida no senso comum.

Para além de uma campanha de doação de alimentos, ela constituía não só a concepção da força da sociedade, já clara em Betinho, mas também a expressão crescente da limitação das vias institucionais tradicionais, dos partidos políticos em expressar os anseios de parte significativa da sociedade.

Em sua natureza, encontrava-se a mensagem da necessidade urgente do Estado de se fazer representar a sociedade como um todo, ao invés de se concentrar 
apenas em suas próprias estruturas burocráticas, ou em poucas e abastadas parcelas da sociedade. Começar por tomar a iniciativa de fazer o que seria uma função do Estado (doar alimentos), compreendida por muitos como mero assistencialismo, constituía uma forma de protestar, de constranger o Estado para forçá-lo a fazer as reformas estruturais que pusessem fim à miséria e à exclusão.

Um elemento que acompanhou o argumento não apenas da trajetória de Betinho, mas da Campanha foi a necessidade de defender o afastamento do Estado de suas próprias estruturas burocratizadas, que o tornavam como que, um ente estranho à sociedade.

Entretanto, é necessário esclarecer que as objeções de Betinho ao Estado constituem uma crítica distinta daquela realizada pelos liberais, por exemplo. Ao invés de reivindicar por sua diminuição - como propunham os liberais - as objeções de Betinho ao Estado reivindicavam sua transformação. Seu papel deveria ser o de servir a sociedade, de criar condições para a emergência da efetiva cidadania de todos. Essa diretriz é reafirmada por Betinho no processo eleitoral de 1994:

\begin{abstract}
Meu antiestatismo não tem a mesma origem do pensamento neoliberal. Sou crítico do Estado porque quero democratizá-lo radicalmente, submetê-lo radicalmente ao controle da sociedade, da cidadania (...). Para mim, as eleições de outubro não têm o caráter de definir nosso futuro. Quem decide o nosso futuro somos nós, a cada dia, hora, minuto de uma ação política contínua que não se esgota em outubro ou novembro (SOUZA, 1994, p .1 b).
\end{abstract}

A capacidade de mobilização da sociedade para pressionar o Estado a modificar suas prioridades talvez seja um dos aspectos mais originais que Betinho compreendeu ainda na década de 1980. Essa compreensão, em boa medida, confirmou-se nas ruas na campanha das diretas, nas eleições de 1989 e na campanha pelo impeachment.

É imbuído na fé da capacidade de organização e do descontentamento da sociedade com o distanciamento do Estado, assim como da configuração da estrutura social brasileira, que a Campanha ganha condições de ser compreendida 
em sua natureza mais fundamental. Daí, a incompreensão de muitos ao reduzí-la a simples campanha de doação de alimentos:

Desde que a Ação da Cidadania começou, as crenças pessimistas sobre a qualidade das pessoas no Brasil foram sendo desmentidas uma a uma: as pessoas não são solidárias, só pensam em si e em suas famílias. Não é verdade. A solidariedade é a moeda real da sociedade brasileira. Dar sem receber, oferecer sem cobrar. As pessoas sempre esperam das outras, não tomam iniciativas, não são capazes, não criam fatos novos. Não é verdade. A Ação da Cidadania, essa luta pela democracia, cria, inventa, inova, não espera, toma iniciativa, transforma a realidade pelas próprias mãos e não pelas mãos dos outros. Dá o que tem, divide com os outros, se emociona com a alegria dos destituídos, não vira a cara diante do sofrimento (SOUZA, 1996, p. 74 a).

A resposta da sociedade ao chamamento da Campanha revelou como sua aposta encontrava-se empiricamente fundamentada, com respaldo na realidade concreta. Betinho, pode-se afirmar, teve uma compreensão avançada, no sentido de realizar uma leitura profunda sobre a representação cada vez mais fragilizada e menos representativa da estrutura institucional e político-partidária brasileira, de sua distância para com a sociedade.

A escolha de Betinho pela atuação numa arena de ação política alheia às estruturas institucionais do Estado é colocada de forma contundente no contexto das eleições de 1994, quando responde à manifestação pública de Oded Grajew ${ }^{23}$, que solicitava o apoio e engajamento de Betinho em favor da candidatura de Lula à presidência, argumentando que sem um governo que buscasse uma mudança social, todas as iniciativas da Campanha contra a fome seriam inócuas (PANDOLFI e HEYMANN, 2005, p. 215).

Em resposta à provocação de Grajew, Betinho expõe sua visão de forma clara em que, mais importante que as eleições ou o Estado, seria a mobilização e engajamento da sociedade. $\mathrm{E}$, de que não se pode mudar o governo sem mudar a sociedade:

\footnotetext{
${ }^{23}$ Oded Grajew, 1944, empresário israelense, naturalizado brasileiro. Com longa e reconhecida atuação na defesa do engajamento das empresas com sua responsabilidade social. Foi presidente da fundação Abrinq pelos direitos da criança e do adolescente. Era simpatizante da campanha de Lula a presidência da República.
} 
Começo por dizer que minha crença em governo, qualquer governo, não é a mesma que você expressa (...) meu olhar e minha atenção estão concentrados sobre a sociedade. Por isso, para mim mais importante que o Estado é a sociedade, mais importante que qualquer governo é a Ação da Cidadania. Esse é hoje o meu credo. Entre o presidente e o cidadão, fico com o cidadão (SOUZA Apud PANDOLFI e HEYMANN, 2005, p. 216).

Nesta perspectiva, Betinho reafirma de forma contundente suas diferenças e desconfianças em relação à esquerda brasileira que, em sua opinião, continuava a se pensar como salvadora do universo, fora da qual não haveria bom caminho. Cabe lembrar que por semelhante forma de pensamento, Betinho havia deixado a Ação Popular duas décadas antes:

\begin{abstract}
Não quero o Estado no planalto, mas na planície. Não quero o presidente, mas o cidadão. Não quero o salvador, mas o funcionário público eleito para gerenciar o bem comum. Me assusta o estatismo da esquerda, a crença no poder dos que sonham com a mudança a partir da mágica do poder (...). O PT no fundo, ainda se crê um partido único, aquele que detém a verdade, o caminho e a luz, a coerência, a ética. Essa visão que tem de si mesmo me assusta (SOUZA Apud PANDOLFI; HEYMANN, 2005, p. 216 e 217).
\end{abstract}

O Estado para Betinho, mesmo tendo sua importância, era secundário se comparado com a sociedade. Era a partir dela que se fariam as grandes mudanças. Sem ela, tampouco se lograria alguma mudança efetiva.

A experiência de construção de uma legítima democracia teria em seu DNA a cidadania e a solidariedade, não estaria baseada nos palácios, mas nas experiências cotidianas de ação política na sociedade. Não seria percebida apenas a cada quatro anos através do sufrágio universal, mas diariamente nas mais diversas lutas do dia-a-dia.

A cidadania constituía a experiência da corresponsabilidade da vida em sociedade, cotidianamente, não apenas em determinados momentos, por isso transcendia a obrigação de votar ou a mera crítica aos políticos (PLASENCIA, 1998, p. 79).

É também notável que sua atuação no campo das ONGs no Brasil separada das esferas institucionais, como na experiência da Ação da Cidadania, confere à figura 
de Betinho a consolidação de sua imagem de ator político que organizava suas ações autônomas em relação às vias institucionais, dando a sua figura autoridade $\mathrm{e}$ familiaridade no diálogo direto com a sociedade.

Como agente singular no universo das ONGs, Betinho possuía também uma posição específica de onde falar à sociedade, espaço este que não se confundia com os partidos ou o Estado (LANDIM, 1998, P. 249; LIMA NETO, 2013, p. 127). Um exemplo a este respeito é o fato observado em sua recusa de trabalhar diretamente nas estruturas do Estado quando, ainda em 1992, Betinho rejeitou o convite feito pelo então presidente Itamar Franco para dirigir o Conselho de Segurança Alimentar (CONSEA). Sua reputação solidifica-se ainda mais a partir destas escolhas. Seu intento não era o de conseguir algum cargo no Estado, mas trabalhar junto à sociedade

Um dos aspectos que mais chamou a atenção no desenrolar da Campanha, no que se refere à adesão da sociedade observado por LANDIM (2013), é o caráter essencialmente popular dos doadores e da organização dos comitês da Campanha. Sendo significativa a participação de pessoas de origem popular, muitas das quais não possuíam experiências anteriores de engajamento político. Esse "chamamento à sociedade" da Campanha trouxe para a ação pessoas que em sua maior parte se encontravam alheias à temática dos problemas sociais até então (LANDIM, 2013, p. 273).

Nesse sentido, a Campanha conseguiu cumprir uma função extremamente importante: engajar na militância por uma causa social pessoas até então estranhas a esta temática. Ela produziu milhares de novos militantes.

\subsection{Campanha como proposta de radicalização da democracia}

O contexto da redemocratização no Brasil trouxe para a cena do espaço público novas - ou antigas - demandas de amplos e distintos setores da sociedade. A emergência desses atores sociais contribui muito para ajudar o desenvolvimento da luta pela expansão das fronteiras da democracia que se buscava forjar. 
O caso da Ação da Cidadania, por exemplo, trouxe para a discussão pública a agenda da intolerância em relação à fome e à miséria a ser incluída no debate como a necessidade da democracia de se fazer valer para toda a população, não apenas para alguns. Os limites da democracia, especialmente neste momento do início da década de 1990, encontravam-se relacionados à capacidade dos atores sociais tornarem públicas suas demandas:

\begin{abstract}
A emergência de novos atores coletivos representa, genericamente, o alargamento das fronteiras temáticas do espaço público, pois eles fazem com que as atenções públicas se voltem para novas situaçõesproblema, trazendo ainda formas de percepção - e, eventualmente, soluções - inéditas para problemas previamente detectados. Na história brasileira recente, pode-se constatar com clareza que o aparecimento de certos movimentos sociais desencadeia ampla discussão de temas até então não entendidos e problematizados como questões de relevância social (COSTA, 2002, p. 75).
\end{abstract}

O centro da problemática levantada por Betinho na Campanha da Ação da Cidadania, já no contexto dos anos 90, quando as instituições democráticas já se encontravam relativamente consolidadas, concentrou-se na exposição e defesa da ideia de que não bastava apenas a conquista da democracia política. Era preciso garantir na democracia a plena inclusão, a garantia da efetivação dos direitos indiscriminadamente.

Buscando denunciar o grande entrave da democracia brasileira constituída sob a orientação da perspectiva liberal, que era a de não incluir a todos, a Campanha tinha como alvo o chamamento à indignação em relação à exclusão social e econômica de milhares de pessoas. Nesta conotação a democracia tornar-se-ia uma farsa para Betinho. Uma ilusão construída pela minoria que dela se beneficiava.

Radicalizar a democracia é um termo que definia a proposta de Betinho e da Ação de Cidadania. Consistia em superar os limites de uma sociedade que não seria pensada para todos, onde a maioria não cabia, não seria incluída. $\mathrm{O}$ grande entrave à democracia no Brasil, na visão de Betinho, era sua limitação, uma vez que ela não funcionava para todos. Para ele, só radicalizando a democracia seria possível fazer com que ela valesse para todos (SOUZA, 1987, p. 22). 
O eixo nessa busca incessante da Campanha coloca-se como exemplar, pois se inicia com os dois pés no chão, com objetivo possível, o de doar alimentos aos que dele necessitavam com urgência. Em seguida, a busca por um ideal, por uma utopia, a inclusão universal de todos os cidadãos na democracia. A síntese das ideias fundamentais de Betinho expostas na Campanha e que perpassam esta compreensão são traduzidas da seguinte forma:

\begin{abstract}
No combate à fome há o germe da mudança do país. Começa por rejeitar o que era tido como inevitável. Todos podem e devem comer, trabalhar e obter uma renda digna, ter escola, saúde, saneamento básico, educação, acesso à cultura. Ninguém deve viver na miséria. Todos têm direito à vida digna, à cidadania. A sociedade existe para isso. Ou, então, ela simplesmente não presta para nada. O Estado só tem sentido se é um instrumento dessas garantias. A política, os partidos, as instituições, as leis só servem para isso (SOUZA, 1994, p. $34 \mathrm{~d})$.
\end{abstract}

Essa utopia buscada pela Campanha constituía a decorrência de uma solidificada compreensão empírica da realidade. As condições da economia brasileira, que mesmo com seus problemas, já eram pujantes, isto é, teria ela todas as condições de garantir o mínimo digno e necessário a todos. Portanto, não haveria nenhuma justificativa razoável para a exclusão de milhares de pessoas. A Campanha como proposta de radicalização da democracia e busca pela utopia traduz-se da seguinte maneira:

\begin{abstract}
Queremos transformar o mundo. Queremos tudo de novo...queremos erradicar um passado que nos envergonha a todos e construir um futuro que nos dignifica. Queremos a ética na política, a economia produzindo para todos, a cidadania se afirmando e transformando tudo o que toca. Queremos um mundo capaz de enterrar a velha injustiça, o cinismo, a indiferença, a violência, a ganância, a fome do lucro a todo custo e de fazer nascer uma nova sociedade igualitária, solidária, fraterna, participativa e diversa. Queremos um novo mundo, um mundo jovem. Romper os compromissos com a velha sociedade, a velha ordem, o velho progresso que nos transformou nessa fantástica Casa Grande e Senzala cujo nome é Brasil (SOUZA Apud PLASENCIA, 1998, p.73).
\end{abstract}

Pensada a partir desta perspectiva, a Ação da Cidadania só pode ser efetivamente compreendida se localizada como parte de um intento maior, cujas raízes mais fundamentais se encontram ainda na biografia de Betinho, no contexto 
de suas diferenças com a direção da Ação Popular em fins da década de 1960 e nas reflexões que se solidificaram no exilio, tomando sua forma final no regresso ao Brasil quando abandona de vez a via político-partidária como caminho para a mudança na estrutura social. A Campanha contra a Fome constitui um chamado para a transformação da sociedade a partir de um gesto simples e aparentemente despretensioso.

Tal como um iceberg, a Campanha, se percebida em sua anatomia, continha elementos fundamentais de crença na mobilização da sociedade para a transformação da estrutura econômica e social que, no entanto, permanecia submersa, invisível aos que a identificavam como uma simples campanha assistencial de doação de alimentos. 


\section{A Campanha: suas virtudes, vícios e legado para a sociedade}

\subsection{Objeções à organização da Campanha}

A Campanha como um movimento de amplitude nacional suscitou, como era de se esperar, inúmeras manifestações, inclusive objeções, algumas delas já expostas neste trabalho. Uma das críticas mais significativas, no entanto, era aquela que recaía sobre a proposta e o formato da Campanha no que diz respeito a sua estrutura organizacional.

A ausência de uma estrutura de organização formal, se por um lado constituía uma novidade e fator possibilitador de rápida expansão, por outro criava empecilhos para a continuidade da Campanha a médio e a longo prazo.

A exigência de descentralização e autonomia dos comitês, tanto em sua organização como no funcionamento e distribuição, buscavam promover a diversidade e o pluralismo como elemento presente na base de organização e filosofia da Campanha (PLASENCIA, 1998, p. 87).

Se por um lado tal caráter possibilitou à Campanha contar com a contribuição de pessoas de diversos credos, opiniões, partidos, religiões, etc., além de estimular e ensejar uma nova proposta de organização de ação política, por outro este modus operandi custou um alto preço no sentido de comprometer a formação de uma estrutura que se mantivesse a médio e a longo prazo, sacrificando inclusive sua continuidade. Sobre este assunto, Frei Betto observou algumas críticas à forma como a Campanha teria sido conduzida por Betinho:

Eu tinha uma crítica muito forte: estava centrada muito na pessoa do Betinho. Cheguei a falar, em reunião aqui no Rio, que ele não socializava o poder e ele ficou muito chateado. Eu sentia isso, que no momento em que ele desaparecesse... Ele tomou uma posição exatamente contrária à minha; era contra organizar demais. Eu falei: o problema é que tem que organizar, porque o movimento tem que ter continuidade, independente de suas lideranças. Era ele o movimento e ele tinha dificuldade, por exemplo, de ter um cara que articulasse o movimento no Nordeste, outro no Sul, e dividir o poder e debater com esses caras os rumos do movimento. Eu sempre fui da posição inversa. Eu realmente defendia que o movimento tinha que ser mais orgânico. 
Eu sentia que as coisas vinham num embalo e depois acabavam (FREI BETTO Apud FREIRE, 2013, p.8).

A ausência de cuidado mais pormenorizado com a formalização da Campanha visando sua continuidade era, do ponto de vista de Betinho, minimizado diante do objetivo maior e urgente de tocar o movimento, de fazer a Campanha andar (PANDOLFI; GAZIR; CORREA, 2012, p. 166).

A característica de urgência em relação às ações no presente aproxima, em certa medida, a postura de Betinho ao que Weber classificaria como a tipologia da liderança carismática, para o qual a grandeza e a centralidade das necessidades das realizações urgentes do presente excluiriam a atenção necessária às ações de longo prazo.

Essa tipologia de liderança, no contexto brasileiro, foi identificada por Helena Bomeny (2001) em outro notável mineiro, Darcy Ribeiro, para quem, frente às grandes mobilizações, as responsabilidades oficiais eram minimizadas ou mesmo ignoradas:

\footnotetext{
Os movimentos liderados por personagens políticos (...) com o perfil de Darcy Ribeiro são entusiásticos, totalizadores, sintonizados com mobilizações em que as fronteiras hierárquicas se dissolvem (...). Esse estado de espirito e esse tipo de envolvimento se opõem ao rotineiro e à disciplina, porque a emoção e a independência (...) impedem a aceitação, pelo líder, de submissão à repetição (BOMENY, 2008, p. 123).
}

$O$ perfil de Betinho certamente não atingia o grau de intensidade do personalismo de Darcy Ribeiro. No entanto, é possível notar que, no calor da luta pela construção e ampliação da Campanha, Betinho tenha caído na tentação de não pensar em desenvolver a Campanha a médio e a longo prazo, deixando-se absorver pelas necessidades urgentes.

Também é verdade que, nos anos seguintes ao de 1993, a Campanha tentou chamar a atenção para outras agendas além da doação de alimentos. Como em 1994, em que se concentrou também na geração de empregos, buscando afirmar o sentido de uma proposta mais estrutural que visasse combater o problema da 
miséria de forma contínua (SOUZA, 1994, p.40 c; PANDOLFI e HEYMANN, 2005, p.184).

Em 1995, a Campanha buscou chamar atenção para a questão da falta de acesso à terra como elemento fomentador da miséria e das desigualdades, sendo marcada inclusive pela entrega da "Carta da terra" por Betinho ao presidente Fernando Henrique Cardoso em sua posse no dia $1^{\circ}$ de janeiro de 1995, na busca de apoio do governo para enfrentar o problema da concentração de terras (PANDOLFI e HEYMANN, 2005, p.185).

A despeito do incremento dessas temáticas da Campanha, a manutenção de um projeto de baixa corporificação institucional significou a opção de uma escolha realizada por Betinho.

Em sua defesa, contrapondo-se a estas objeções, Betinho mobilizava o argumento da primazia e novidade da organização descentralizada, destacando seus aspectos positivos:

Mais um motivo de surpresa foi o fato de que a descentralização se mostrou um método eficiente de trabalho. Não há hierarquias, comando central, determinação única na campanha. Há uma aposta na iniciativa e na autonomia do cidadão, uma atitude que sempre foi considerada pela esquerda como espontaneísta. Na prática, a Ação da Cidadania mostrou que o cidadão tem grande capacidade mobilizadora (SOUZA, 1994, p. 63 e).

Ao direcionar o perfil da Campanha nesta direção, Betinho viu-se numa "faca de dois gumes", uma vez que a mesma característica que conferia legitimidade e inovação à campanha se constituía também como potencial entrave à sua continuidade. Nas palavras de Betinho, os traços da Campanha são descritos da seguinte forma:

As palavras-chave são descentralização, autonomia e iniciativa. O movimento é totalmente descentralizado, uma vez que ele não pertence a uma pessoa ou grupo, mas à cidadania, à sociedade. Cada cidadão é responsável por seus atos. O cidadão se organiza, mas com total liberdade. Cada comitê define o que fazer na luta contra a fome. O movimento é autônomo porque não está subordinado a nenhum partido político, a nenhuma igreja, a nenhum líder. E configura um movimento de iniciativas pois propõe que cada cidadão parta efetivamente para a ação. É um movimento de ação. Portanto, não se trata de uma campanha ocasional, que começa em janeiro e termina 
em dezembro. É um movimento que deposita total confiança na ética da cidadania (Entrevista à Betinho, SOUZA, 1994, p. 58).

No contexto da escolha trilhada para os rumos da Campanha, de consequências inevitáveis, que pendiam entre a segurança da continuidade e a proposta de singularidade, Betinho trilhou o caminho da segunda, escolha pela qual fez da Campanha e de sua própria biografia um acontecimento monumental na história recente da sociedade brasileira.

\subsection{Respostas da sociedade ao chamamento da Campanha}

A experiência da Campanha auxilia-nos a pensar hoje o conjunto das experiências responsáveis por animar e desenvolver a sociedade civil brasileira. Ela constitui um momento exemplar para pensar o papel do protagonismo da sociedade, bem como de sua relação com o Estado.

A imersão no estudo de sua experiência nos conduz aos caminhos trilhados por ela, a qual sugere o aparecimento de outras possibilidades de ação política em estado latente de desenvolvimento, cuja Campanha teve o mérito de estimular.

Como observa Landim (1998), a Campanha para além dos desdobramentos sociais e econômicos constitui-se como momento que traz à tona dimensões menos conhecidas e pesquisadas da sociedade, bem como constitui-se como um lócus fundamental de algumas de suas recentes transformações (LANDIM, 1998, p 248).

O balanço de seu legado, medidos os erros e acertos, revela um saldo positivo que encontra afinidade eletiva entre a compreensão da crença na força de mobilização da sociedade e a sua disponibilidade para atender e compreender o chamado da Campanha:

Tudo isso e muito mais só foi possível porque a sociedade apostou numa nova forma de fazer política, apostou na iniciativa de cada cidadão e cidadã, na descentralização como forma de organização, na iniciativa como forma de estimular a criatividade e as soluções 
próprias; apostou na parceria entre quem tem o que dar e quem precisa receber (SOUZA, 1994, p. 62 e).

É digno de ser notada também, para além do expressivo engajamento da sociedade na Campanha, a adesão de vários setores da sociedade e entidades organizadas como, por exemplo, a iniciativa de brasileiros residentes no exterior que chegaram a criar comitês de campanha na França, Suíça, Itália e Japão, dentre outros países (SOUZA, 1994, p. 62 e).

Com respeito a este tema, dentre o conjunto das correspondências da população destinadas a Betinho, destacam-se aquelas vindas de brasileiros residentes no exterior, que se haviam sensibilizado com a Campanha e de alguma forma se propuseram a ajudar e/ou dar contribuições e ideias (CPDOC/FGV, Arquivo HS ac/c 1993.01.02, folha, folhas I-12; II-1; II-78).

Os comitês organizados por funcionários de empresas públicas tiveram também um destaque significativo, sobretudo dos funcionários de bancos públicos estatais como Caixa e Banco do Brasil.

Como resultado desta mobilização, foi fundado o Comitê das Empresas Públicas no Combate à Fome e pela Vida, ou simplesmente Comitê das Estatais, reunindo empresas como Light, Petrobrás, Furnas, Eletrobrás, Correios, além de instituições financeiras, órgãos de fomentos, prestadores de serviço e instituições acadêmicas. Estes comitês, além de se articularem em torno da criação de projetos sociais, estimulavam a participação de seus funcionários na formação de comitês por todo o país (LANDIM, 1998, p. 257).

A incrível aceitação e assimilação da Campanha por parte da sociedade deu-se também no caráter didático que esta experiência possibilitou a ela mesma, como a descoberta de sua força:

O que se pode perceber hoje é que a Ação da Cidadania, um ano depois de ganhar as ruas, trouxe ao cidadão brasileiro, uma nova forma de fazer política, com princípios e estratégias que sempre existiram de forma dispersa na sociedade. O primeiro sinal de mudança foi a constatação, inédita no Brasil, de que é possível agir a partir da sociedade e não a partir do Estado. Foi uma mudança no olhar e no andar político (SOUZA, 1994, p. 62 e 63 e). 
A Ação da Cidadania, como um movimento advindo essencialmente da força da sociedade, possibilitou a ela própria descobrir a dimensão de sua força. Num país em que os canais formais de participação política se mostravam incapazes ou descompromissados em agir para a mudança, a descoberta pela sociedade de sua força tornava-se, sobremaneira, relevante.

\subsection{Recepção da sociedade a partir das correspondências da população a Betinho}

A análise das correspondências da população endereçadas a Betinho constitui, neste trabalho, uma das formas de observar o impacto de suas ações através da Campanha. Portanto, o objetivo é avaliar se o argumento principal deste trabalho encontra, no conjunto das cartas, algum tipo de convergência ou apontamentos favoráveis; se ela sensibiliza a sociedade, sobretudo aquelas pessoas até então não militantes; se funcionou também como instrumento pedagógico de esclarecimento das questões e problemas centrais da sociedade.

Tal argumento consiste em compreender a experiência da Ação da Cidadania como parte de um projeto maior, delineado na experiência e no amadurecimento de Betinho desde o exílio, que passa por concentrar o eixo de suas ações por mudança social não mais unicamente no Estado, ou nas organizações políticas tradicionais, mas nas novas possibilidades de engajamento político a partir da sociedade civil. Isto é, organizando as mudanças da sociedade para o Estado e não o caminho inverso.

Sem perder de vista o horizonte das mudanças nas estruturas sociais e econômicas, a Campanha organizou seu discurso ao propor grandes mudanças a partir de ações possíveis e ao alcance de todos, como a doação de alimentos.

Para este trabalho, do total do conjunto de manuscritos do acervo de Betinho localizado no Centro de Pesquisa e Documentação da Fundação Getúlio Vargas (CPDOC/FGV), no Rio de Janeiro, analisamos apenas as correspondências 
remetidas por pessoas físicas, ficando excluídas as de empresas, instituições políticas e entidades de maneira geral.

Foi analisado um total de 248 correspondências, das quais 79 constituíam declarações de alunos da $7^{\mathrm{a}}$ série do Colégio Pio XII em João Pessoa, que por possuírem conteúdo bastante similar, consideramos como uma unidade. As correspondências ficaram agrupadas, então, em 169 unidades analisadas.

Estas correspondências foram resultado do engajamento dos alunos sob o patrocínio da Escola e professores, que participaram da Campanha. Citamos a carta de uma aluna da $7^{a}$ série que exemplifica a natureza e conteúdo das demais:

Betinho, você está de parabéns pelo seu excelente trabalho que vem executando em favor de nossa sociedade. Lhe admiro muito e vejo em você a paz e a bondade. O que mais admiro em você é a sua coragem e perseverança. Adorei a campanha que você lançou em 1993 contra a fome (...) na qual pude participar, nessa campanha você mostrou que participando não iríamos mudar o mundo mas estaríamos fazendo a nossa parte, achei isso super legal e é uma pena que pessoas como você existem poucas no mundo (CPDOC/FGV, Arquivo HS ac/c 1993.01.02, folha III 21).

Apesar de quase a totalidade das correspondências possuírem remetente, contendo todas as identificações como nome, sobrenome e endereço, os trechos que seguirão não serão identificados nominalmente a fim de preservar os remetentes.

Do conjunto das correspondências analisadas, em sua distribuição por sexo, revela-se uma ligeira superioridade das correspondências remetidas por mulheres, como apresentado na tabela 1:

Tabela 1

\begin{tabular}{|c|c|c|}
\hline & Quantidade & Porcentagem \\
\hline Homens & 75 & $40 \%$ \\
\hline Mulheres & 106 & $55 \%$ \\
\hline Não identificados & 08 & $5 \%$ \\
\hline
\end{tabular}

Tabela 1: Distribuição das correspondências analisadas por sexo dos remetentes

* Em uma mesma correspondência pode haver mais de um remetente 
Quanto à origem geográfica das correspondências, observa-se que, em geral, vinham dos grandes centros urbanos, sobretudo da região sudeste. Apesar de se constatarem a presença de todas as regiões do país, as cidades do Rio de Janeiro e São Paulo concentram a maioria das correspondências, como observado na tabela 2:

Tabela 2

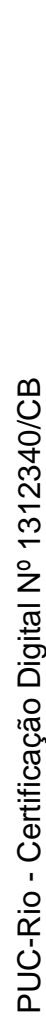

\begin{tabular}{|c|c|c|}
\hline Cidade & Quantidade & Porcentagem \\
\hline Rio de Janeiro & 38 & $23 \%$ \\
\hline São Paulo & 30 & $17 \%$ \\
\hline Belo Horizonte & 05 & $3,7 \%$ \\
\hline Niterói & 04 & $3 \%$ \\
\hline João Pessoa & 04 & $3,7 \%$ \\
\hline Exterior & 05 & $5,7 \%$ \\
\hline Não identificados & 09 & $40,9 \%$ \\
\hline Outras cidades & 74 & $100 \%$ \\
\hline Total & 169 & \\
\hline
\end{tabular}

Tabela 2: Distribuição das correspondências analisadas por cidade dos remetentes

Se agrupadas pelas unidades da Federação das quais se originaram, podemos observar, com maior clareza, a distribuição da representatividade e abrangência da Campanha que obteve alcance nacional e internacional. Conforme se observa na tabela 3, as correspondências vinham de 20 estados diferentes. Novamente, os estados da região sudeste, com destaque para Rio de Janeiro e São Paulo, são os que mais concentram as correspondências. Além daquelas advindas do exterior, em geral, brasileiros que residiam por lá e buscavam de alguma maneira contribuir com a Campanha: 
Tabela 3

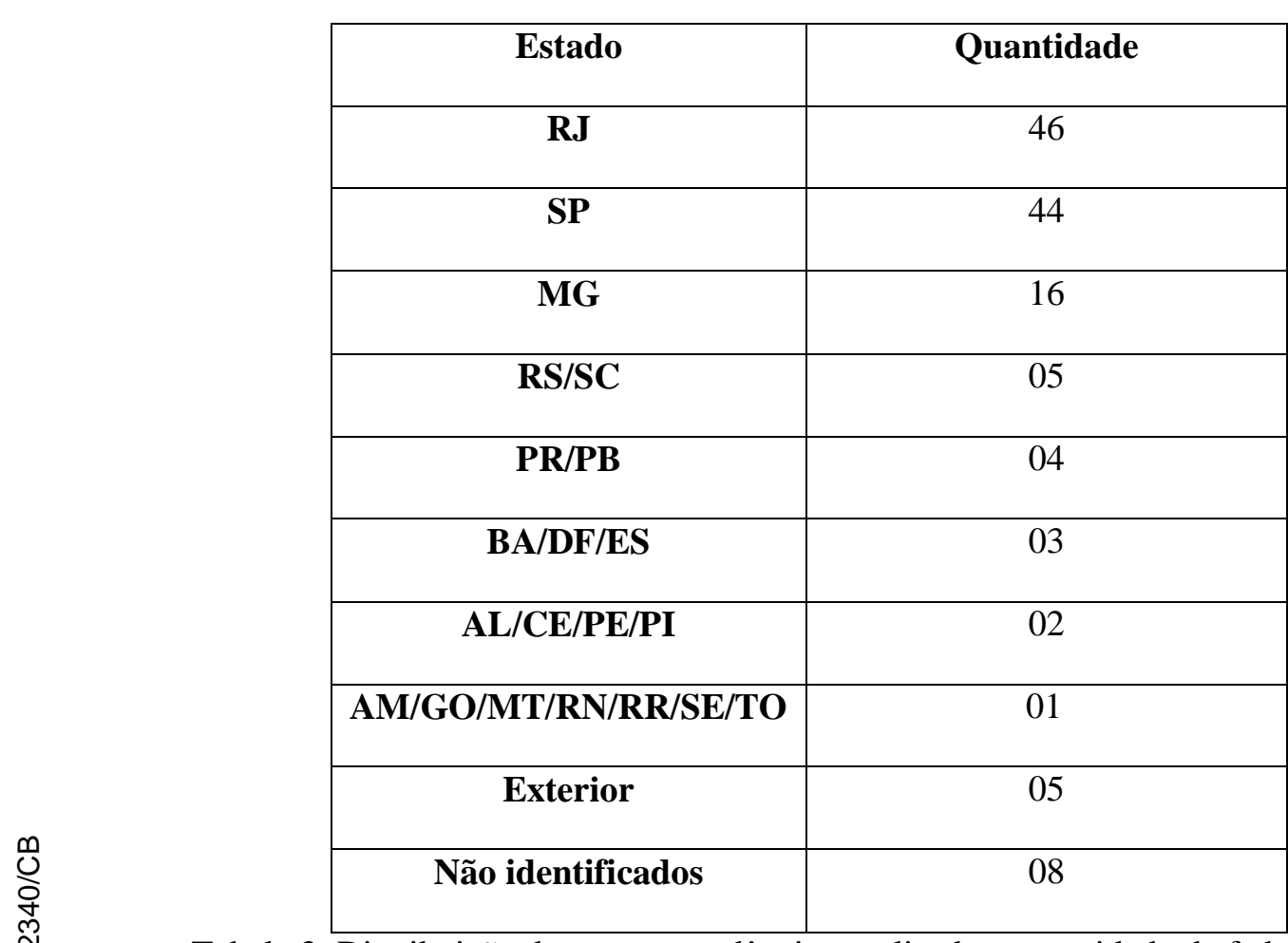

Tabela 3: Distribuição das correspondências analisadas por unidade da federação dos remetentes

Em relação a seu conteúdo, de maneira geral, as correspondências analisadas apontam de forma clara para a sensibilização da população, algo que fica evidente na maioria das cartas. Um dos elementos que mais aparece nas correspondências: as felicitações e os testemunhos de sensibilização provocados pela postura de Betinho e da experiência da Campanha.

No entanto, dois elementos chamam a atenção no conteúdo das correspondências e que merecem uma análise mais aprofundada são: 1) a disponibilização da população para, de alguma maneira, auxiliar na Campanha, mesmo sem saber como; 2) a quantidade de "soluções" e proposições levadas a Betinho pela população. A distribuição por conteúdo está disposta na tabela 4 . 
Tabela 4

\begin{tabular}{|c|c|}
\hline Assunto & Quantidade \\
\hline Parabenizam pela Campanha & 77 \\
\hline $\begin{array}{c}\text { Sugestões para a Campanha (exposição de "teses" para resolver } \\
\text { os problemas nacionais) }\end{array}$ & 37 \\
\hline Dispõem-se a colaborar com a Campanha & 35 \\
\hline Solicitação de encontros/visitas (convites para palestras) & 11 \\
\hline Envia/cede direitos de textos, músicas e poemas & 17 \\
\hline $\begin{array}{l}\text { Pedidos de informações/materiais sobre a Campanha e ou } \\
\text { criação de comitês }\end{array}$ & 04 \\
\hline Comentários diversos & 11 \\
\hline Pedidos de ajuda diversos & 06 \\
\hline $\begin{array}{c}\text { Pedidos oportunistas (lançamento ou divulgação de seus próprios } \\
\text { materiais) }\end{array}$ & 03 \\
\hline Outros & 06 \\
\hline
\end{tabular}

Tabela 4: Distribuição das correspondências analisadas pela natureza de seu conteúdo.

* Em uma mesma correspondência podem haver mais de um assunto

No conjunto dos conteúdos das correspondências analisadas, remetidas por pessoas físicas a Betinho, chama a atenção os pedidos de orientação para como se engajar na Campanha - um total de 35 correspondências, contabilizando $20 \%$ do total -, revelando de forma significativa o mérito de convocar a sociedade, as pessoas, orientando o centro de suas ações na sociedade, buscando atuar numa esfera distinta das instituições tradicionais.

Também chama a atenção o fato de que boa parte das pessoas que se comunicavam com Betinho a fim de se engajar e contribuir com a Campanha revelavam pouca ou nenhuma experiência como militante. Apesar disso, queriam agir, ajudar, mesmo sem a noção clara de como proceder. A Campanha e a experiência de Betinho eram vistas como um referencial para estas pessoas. 
A atração de pessoas, até então, não engajadas na ação contra a miséria e as desigualdades torna a Campanha singular sob o ponto de vista de sua originalidade. Ela não disputou espaço e militantes com outras organizações ou movimentos sociais. Ela mobilizou, em sua maioria, pessoas que se encontravam fora da órbita das discussões sobre os problemas sociais (LANDIM, 1998, p.247 e 248).

Ao realizar esta proeza, a Campanha não apenas angariou um conjunto maior de militantes. Ela contribuiu, em grande medida, com o redirecionamento da agenda das mudanças na estrutura social, agregando também um significativo conjunto de indivíduos até então, alheios a esta discussão.

Outro aspecto que chama a atenção nas correspondências é a significativa quantidade de "soluções" propostas a Betinho pela população. No conjunto dessas proposições, as correspondências revelam as mais diversas sugestões com vistas a aperfeiçoar a Campanha e a resolver os problemas sociais do Brasil.

Estas "soluções" iam desde sugestões para plantar/produzir mais alimentos até a proposições de contribuição financeira a partir de descontos no valor de um real ( R \$ 1,00) no salário de cada trabalhador, para angariar fundos contra a pobreza. Essas correspondências em geral, reconheciam a importância da Campanha e o mérito de Betinho, mas propunham que, para que fossem superados os problemas estruturais seriam necessárias a inclusão de outras medidas as quais se encarregavam de propor a Betinho.

A sugestão que poderia ser resumida como a criação de um "imposto contra a fome" aparece claramente em duas correspondências distintas, uma vinda de um homem de Belo Horizonte e outra de uma senhora do Rio de Janeiro. Descrevo a proposta desta última a seguir:

porque em meio a tantos impostos que são criados somente para engordar os cofres de certos políticos corruptos, não se criar um "imposto contra a fome"? Ou seja, cada trabalhador contribuiria com $\mathrm{R} \$ 0,50$ ou $\mathrm{R} \$ 1,00$ de seu salário. Esta contribuição seria destinada à compra e distribuição de mantimentos em meios às classes carentes (CPDOC/FGV, Arquivo HS ac/c 1993.01.02, folha II 85). 
Ainda sobre este aspecto, é significativo lembrar que, mesmo que apareçam de forma confusa, as correspondências nas quais são apresentadas propostas para solucionar os problemas revelam que, em boa medida, a população teria compreendido a natureza fundamental da Campanha, a de que a doação de alimentos constituía apenas o primeiro e mais urgente passo de uma longa jornada.

Nesse sentido, outra "solução" que aparece é a do estímulo à plantação. Ainda que desconsiderada a problemática do acesso à terra no Brasil, as pessoas sentiam-se confortáveis para compartilhar suas sugestões:

\begin{abstract}
Eu estive agora em dezembro/93 viajando por estrada de rodagem no sul da Espanha e Norte do Marrocos (...), só vi plantação de olivas e uvas e no Marrocos a mesma coisa, não se vê um mato, capim nenhuma terra que não esteja plantada (...). Quando desci do avião aqui em São Paulo só vi mato. Prezado Sr e se você começasse a campanha: plante, plante, plante, plante, não permita nenhum pedaço de terra sem plantar, aproveitar tudo, tudo mesmo, será que não seria uma boa? Pelo rádio, tv, jornal, revistas, etc. Tudo plantado, milho, feijão, cana, batata, verdura, legumes, cereais, etc. Desculpe, V.S. não acha? Tanta terra e só mato? Não é o caso de plantar? E acabar com a fome no mundo? Cada um aproveitar o pedaço de terra que puder. É só começar e o povo pega gosto pela coisa e aí deslancha de vez (CPDOC/FGV, Arquivo HS ac/c 1993.01.02, folha II 8).
\end{abstract}

Uma correspondência que traduz o espírito dessa modalidade de correspondências é enviada por um morador de Brasília. Nela, o cidadão propõe uma "tese" que classifica de "vencer o desemprego...trabalhando menos", cuja proposta é diminuir a jornada de trabalho para abarcar maior quantidade de trabalhadores. Nela, o remetente escreve:

Minha sugestão - que considero revolucionária, é simples, racional e inédita, podendo ser consubstanciada no slogan "vencer a inflação...trabalhando menos", merece uma reflexão profunda, que peço a vossa senhoria. Porque não se estender a jornada de trabalho para doze horas em todas as atividades produtivas, dividindo-a em dois turnos de seis horas corridas no lugar das atuais oito? Com isso se estariam abrindo milhões de novos empregos, reduzindo a miséria e a marginalidade, restituindo-se a dignidade do homem (CPDOC/FGV, Arquivo HS ac/c 1993.01.02, Folha II $38)$. 
Esta modalidade recorrente nas correspondências da população a Betinho - que classificamos como "soluções" -, apesar de boa parte se encontrar carregada de elementos do senso comum e mesmo superficiais, revela como Herbert de Souza, agregando sua imagem à da Campanha, foi capaz de aglutinar a confiança dos brasileiros. A sociedade, de alguma maneira, via nele a personificação de alguém confiável, algo pouco comum entre figuras públicas na sociedade brasileira. Confiável a tal ponto que as pessoas se sentiam confortáveis para expor suas ideias nas cartas remetidas.

Sobre as "soluções", para finalizar, é interessante observar a correspondência de um homem de Florianópolis que propõe cuidar bem das crianças por meio do auxílio do aparato institucional das forças armadas:

\begin{abstract}
Betinho, propósito desta carta é o de apresentar-lhe uma proposta corajosa, eu diria mesmo, ousada, que somente uma pessoa como você seria capaz de transformá-la em realidade (...). A única saída para o Brasil é cuidar, desde já, de sua infância, de suas crianças, mas cuidar mesmo e não de forma demagógica ou cinematográfica como as campanhas da Rede Globo que só servem para promover seus patrocinadores e promotores, sobrando muito pouco para quem realmente precisa (...). Você já parou para pensar que existe no país uma organização, legalmente constituída e espalhada por todo território nacional, com infraestrutura prontinha para receber centenas, talvez milhares de crianças, e prestar-lhes assistência médica, social, lazer, educação, alimentação, abrigo, etc, e tudo isto ao alcance das mãos com um simples decreto presidencial? Não! Pois eu lhe digo já: são as forças armadas (CPDOC/FGV, Arquivo HS ac/c 1993.01.02, folha II 89).
\end{abstract}

A Campanha da Ação da Cidadania, além de se revelar como fruto das decorrências da evolução e compreensão política de Betinho, perspectiva pela qual foi observada neste trabalho, mostrou ser capaz de impactar a sociedade, por dialogar e sensibilizar um público mais amplo que aquele tradicionalmente mobilizado pelos movimentos sociais e instituições políticas tradicionais.

Realizando uma leitura do inconformismo da sociedade com as injustiças sociais, mas de semelhante maneira, compreendendo sua descrença quanto às formas tradicionais de engajamento, a Campanha, a partir de um mote diferenciado, propõe-se a rediscutir os problemas da injusta estrutura social 
brasileira, compreendendo que certamente existia uma capacidade de ação na sociedade.

A Campanha ocupou um vácuo de ação, de uma disposição latente na sociedade que, em geral, se via angustiada diante da desigualdade e da miséria e não enxergava nas formas tradicionais de ação política uma opção de mudança concreta ou confiável. Como observado em uma das correspondências enviadas por uma mulher do Rio de Janeiro:

E é por isso que eu estou aqui. Quero me unir a você e ao seu grupo. Quero tentar fazer alguma coisa por eles, preciso fazer isto! Preciso parar de chorar a noite embaixo do cobertor, quentinho, enquanto muitos estão lá fora, no sereno e no frio (CPDOC/FGV, Arquivo HS ac/c 1993.01.02, Folha, I-63).

O sentimento de renascimento da esperança de que a ação coletiva pudesse trazer à sociedade uma virtude ética já supostamente perdida é um sentimento que aparece no diálogo da população com Betinho.

Se a política partidária convencional encontrava-se desacreditada por parte significativa da população como poder capaz de propor efetivas mudanças sociais, a Campanha, partindo da mobilização da sociedade, mostrava-se capaz de trazer luz aos destituídos de esperança. Como observado em uma correspondência vinda de Bauru, São Paulo:

Sabe Betinho, fui um jovem que passou um bom tempo desacreditando num Brasil melhor. Mas de repente, vi você levantando a bandeira da Campanha Contra a Fome e, quase toda a sociedade colaborando; vi novamente a nossa cultura renascendo (...) de repente, eu tive um ataque de "brasileirismo" e passei a acreditar novamente em nossa pátria! $\mathrm{E}$ você é a principal pessoa que me devolveu a esperança (CPDOC/FGV, Arquivo $\mathrm{HS}$ ac/c 1993.01.02, Folha I-103).

Chama a atenção também, no conjunto das correspondências, a disposição para a ação, ainda que de forma não muito clara. Mesmo sem saber como, as pessoas sentiam-se tocadas pelo discurso da Campanha que era o de pessoalizar cada 
potencial militante, de reconhecer que cada um, ainda que de forma muito simples, poderia se mobilizar para ajudar naquilo que lhe fosse possível.

A chamada à negação do inconformismo e da passividade diante da situação do país ganhou a sociedade não apenas porque a Campanha teve a felicidade de contar com o apoio de artistas, publicitários e dos grandes veículos de comunicação, mas porque a disposição para a mobilização já existia na sociedade. O mérito de Betinho e da Campanha foi saber compreendê-la.

Uma correspondência paradigmática neste sentido é de uma senhora de São Paulo que, mesmo desempregada, se coloca à disposição para colaborar com a Campanha:

Infelizmente eu não possuo poder aquisitivo para auxiliar aqueles que necessitam, e ainda por cima encontro-me desempregada como milhares de pessoas no Brasil, porém, se de alguma outra forma, eu puder colaborar, gostaria que você me escrevesse dizendo como e onde posso me engajar nessa maravilhosa campanha (CPDOC/FGV, Arquivo HS ac/c 1993.01.02 Folha, II 10).

$\mathrm{Na}$ experiência da Campanha, a sociedade demonstrou que, quando acredita numa causa, quando vê credibilidade numa orientação, de pronto se coloca à disposição para intervir. Pode-se também, neste caso, observar que o oposto é verossímil. Muito da falta ou pouco interesse da sociedade na política partidária, eleitoral, por exemplo, poderia ser explicada pelo descrédito, pelo distanciamento das instâncias dos poderes executivo e legislativo em relação ao cotidiano dos brasileiros.

Nesse sentido, o discurso de Betinho, que fazia coro uníssono com sua ação, encontrou eco e adesão na sociedade, uma vez que se diferenciava das mazelas, tanto das instituições do Estado, distantes da sociedade, quanto do mercado. Esta dimensão também pode ser encontrada na correspondência de um homem de meia idade de Campos dos Goytacazes, no estado do Rio de Janeiro:

Diante da impunidade que corre solta no meio dos poderosos endinheirados e, diante de um governo insensível que venera o capital e esquece o homem, temos uma voz que brada corajosamente em defesa dos pobres, das minorias, dessa multidão de desesperados 
brasileiros (CPDOC/FGV, Arquivo HS ac/c 1993.01.02 Folha, III - 149).

Outro aspecto que chama a atenção nas correspondências da população a Betinho está naquelas vindas de crianças e adolescentes, alguns dos quais, efetivamente, se mobilizaram na arrecadação de alimentos em ações conjuntas em suas escolas.

Destaco duas experiências de correspondências mais significativas de mobilizações em escolas. Uma, a do Colégio Diocesano Pio XII, em João Pessoa, que se mobilizou no auxílio à Campanha e, posteriormente, com a ajuda do corpo docente, os alunos da $7^{\text {a }}$ série do Ensino Fundamental, na maioria adolescentes de cerca de 13 anos, enviaram correspondências individuais a Betinho, felicitando-o pela Campanha - total de 79 correspondências enviadas.

Outra, a dos alunos do Centro Educacional Evangélico de Jaraguá do Sul (SC) que participaram da Campanha organizada na Escola, onde realizaram inclusive um evento a fim de promover a Campanha. Descrevemos abaixo a carta assinada coletivamente pelos alunos: Betinho:

\begin{abstract}
Muito sensibilizados com a atual situação da miséria em que vive o povo brasileiro, resolvemos integrar-nos na Campanha 'Ação da Cidadania contra a miséria e pela vida', lançada nacionalmente por você. Envolvemos todas as turmas de nosso colégio, realizando, inclusive um evento denominado NOITE DA SOLIDARIEDADE, no qual houve diversas apresentações artísticas culturais e foi estabelecido como ingresso um quilo de alimento não perecível, obtendo muito sucesso. Arrecadamos durante as três semanas de campanha alimentos, brinquedos, gibis, revistas e livros (...). Na mesma época em que realizávamos a campanha, criou-se também em nossa escola o grêmio estudantil que pretende continuar participando da campanha em 1994. Esperamos que tenhamos contribuído para restabelecer a cidadania e conscientizar as pessoas de nosso convívio da dura realidade que por hora enfrentamos. Desejamos a você muita força e saúde para continuar exercendo esta liderança tão importante para nosso país e que já obteve tão grandes resultados (CPDOC/FGV, Arquivo HS ac/c/ 1993.01.02, Folha, I 97).
\end{abstract}

Tais correspondências chamam a atenção para o efeito didático da Campanha que, certamente, influenciou muitos outros adolescentes a iniciar a prática cidadã 
e solidária, fatores que constituem o fundamento da democracia. Estas ações, na experiência de cada um desses adolescentes certamente tiveram efeitos que superam a simples doação de alimentos.

Por fim, é necessário também destacar o quanto a proposta de descentralização e fortalecimento da Campanha pela base, sem uma estrutura hierárquica rígida, possibilitou o empoderamento de cada cidadão que, ao participar da Campanha, dava o primeiro passo para a experiência cidadã constituída pela solidariedade, mesmo com todas as questões e problemáticas organizacionais que a isso pudessem acarretar, como visto no início deste capítulo.

A Campanha ganhou ampla adesão da sociedade também pelo fato de pessoalizar os que nela militaram. Ao aderirem à Campanha, as pessoas não constituíam apenas mais um número dentro de uma organização impessoal, mas na relação desenvolvida nos comitês, no contato com os receptores, as pessoas incorporavam a proposta da Campanha, identificando nas experiências concretas o problema ao qual a Campanha se propunha a enfrentar.

As características inovadoras da Campanha, à margem das vias tradicionais, abraçando a sociedade, foi compreendida por uma mulher que participou da Campanha e, em correspondência a Betinho, traduz como os atores envolvidos se percebiam neste processo:

\begin{abstract}
Feliz por saber que eu e todas as pessoas que aceitamos a convocação que você nos fez formamos hoje contigo algo de novo: um movimento social onde as pessoas contam. Um movimento que se recria a cada dia a partir das inspirações e intuições de seus participantes. Um movimento onde todos são criadores, onde não há 'dirigentes' que supõem saber melhor que todos os outros qual é o melhor caminho. Por ter sido, e ainda me sentir parte de tudo isto, eu me sinto feliz (CPDOC/FGV, Arquivo HS ac/c 1993.01.02, folha, II 100).
\end{abstract}

As correspondências, nesse sentido, traduzem o quanto a Campanha se mostrou como uma alternativa para buscar os mesmos propósitos de transformação social a partir de novas práticas. O quanto a prática empírica pode e deve caminhar junto à busca utópica. O quanto, a despeito das críticas, a sociedade acolheu a proposta de Betinho. 
Sua experiência revela que, muito diferente do que se pensa, no senso comum, os brasileiros não são acomodados, nem resignados passivos, mas profundamente propensos à ação, ao engajamento, necessitando apenas de uma liderança proba e com credibilidade.

\subsection{Distinção entre caridade e solidariedade}

Um dos debates mais comuns quando se fala da experiência da Campanha da Ação da Cidadania encontra-se numa recorrente acusação à Campanha, a de assistencialismo que, além de não contribuir para modificar as estruturas econômicas e sociais que criavam e mantinham a miséria e as desigualdades, promoveria uma espécie de conformidade e contínua subserviência dos necessitados, além de não atacar o "mal maior".

O suposto caráter assistencialista da Campanha foi uma acusação presente e permanente com a qual ela teve de conviver desde seu início, fato que sempre esteve presente no debate em torno de sua eficácia (LANDIM, 1998, p. 245). Boa parte das vozes críticas vinham da esquerda, que frequentemente percebia a Campanha como uma espécie de desvio - de maneira oportunista ou não - dos problemas e questões mais estratégicos, as chamadas "questões estruturais", tidas como aquelas mudanças mais profundas na estrutura social que, a longo prazo, modificariam as situações concretas de injustiça e desigualdade.

Ocorre que tais mudanças altamente complexas demandariam uma escala de tempo medida em gerações, mas, como gostava de lembrar Betinho, a fome é uma necessidade urgente. Assim, este debate conhecido como emergencial versus estrutural permeou a trajetória da Campanha.

Apesar da existência constante desta polêmica, na visão de Betinho, estes aspectos nunca foram opostos. Ao contrário, eram complementares. Ambas constituíam batalhas de uma mesma guerra. Ainda em 1993, Betinho posicionavase da seguinte maneira: 


\begin{abstract}
A luta contra a miséria tem uma dupla dimensão emergencial e estrutural. A articulação entre essas duas dimensões é complexa e cheia de astúcias. Atuar no emergencial sem considerar o estrutural é contribuir para perpetuar a miséria. Propor o estrutural sem atuar no emergencial é praticar o cinismo de curto prazo em nome da filantropia de longo prazo (SOUZA, 1993, p.1).
\end{abstract}

Se por um lado Betinho não deixou de reconhecer - seja em sua trajetória de vida, seja na Campanha -, a importância fundamental do aspecto estrutural como chave principal das mudanças na sociedade, é verdade também que as ações emergenciais eram percebidas como um dos maiores elementos motivadores da ação. E a ação constituía o elemento essencial para a promoção das mudanças.

Como visto no capítulo inicial, a partir do exílio no Chile, Betinho permite-se realizar uma autocrítica em relação à sua própria experiência e à da esquerda, que falava com frequência em mudanças estruturais, revoluções, sem que a realidade lhes desse o mínimo de aval para pensar mudanças de tal amplitude.

Com o decorrer das experiências do exílio e da própria maturidade, Betinho desenvolveu a compreensão de que se pode mudar não apenas pela via do Estado, mas da sociedade, não apenas colocando na arena as lutas que envolviam o debate estrutural, mas também o emergencial. Além do mais, o grande movimento de avanço realizado por Betinho e, possivelmente, esquecido por seus objetores da esquerda consistiu em identificar os problemas emergenciais e estruturais como faces de uma mesma moeda.

Esse movimento de autocrítica realizado por Betinho desde a experiência no Chile, seguido de seu regresso ao Brasil na Campanha da Ação da Cidadania, constitui uma das chaves para a compreensão de sua identificação como um dos pensadores (e realizadores) mais importante para o Brasil contemporâneo.

Nesse sentido, em relação às criticas colocadas quanto ao suposto assistencialismo e falta de intervenção nas estruturas complexas, Betinho argumentou sempre em favor da defesa destas questões, como a reforma agrária por exemplo. Em sua concepção, o combate à fome não era antagônico à luta por empregos ou à democratização do acesso à terra (NITSCH, 2000, p. 334). 
As críticas aos métodos de ação da Campanha vinham de todas as direções. Se por um lado a esquerda o acusava de assistencialista, por outro a lógica do senso comum, baseada em argumentos de cunho reacionário dizia, desde aquela época, que para mudar era preciso "ensinar a pescar" ao invés de "dar o peixe".

Nesse sentido, algumas das correspondências da população a Betinho traziam esta questão. Junto às congratulações pela disposição do propósito da Campanha, vinham objeções no sentido de que simplesmente doar alimentos estimularia o ócio, além de não resolver completamente o problema. A seguir, uma carta remetida por um homem de meia idade, de São Paulo, japonês que havia emigrado para o Brasil, que, como outras, continha comentários a este respeito:

\begin{abstract}
Problema, principalmente está com povo mesmo. Talvez, senhor pode não concorda a mim. Senhor está fazendo campanha muito bom, bom de mais. Mas, não pode continuar dando só peixes (alimentos). Precisa ensinar algo mais, útil. Tem que dar bom emprego, para todos, com bom salário? Impossível - sim quase impossível (CPDOC/FGV, Arquivo HS ac/c 1993.01.02, folha II 2).
\end{abstract}

As críticas que atribuíam caráter supostamente paternalista estavam muito presentes, sobretudo no primeiro ano da Campanha. Fazendo frente a elas, a Campanha demonstrou ser possível distinguir a solidariedade do assistencialismo. Demonstrou que, para conseguir pescar, era necessário encontrar-se vivo e com saúde e que eram as mudanças do cotidiano que construiriam as mudanças estruturais (SOUZA apud PLASENCIA, 1998, p. 68).

Além de não se colocar contrário a essas questões, Betinho buscava associar o contexto da Campanha às dimensões emergenciais e estruturais do problema da fome e da miséria no Brasil.

Em sua defesa, Betinho utilizava-se, com frequência, do argumento empírico da questão biológica, imortalizada em sua célebre afirmação de que "quem tem fome, tem pressa, e a fome não espera". Essa urgência presente naquele período não poderia ser simplesmente ignorada em favor do argumento - como os setores reacionários sempre fizeram, especialmente durante a ditadura militar - que deslocava a mudança para o futuro, um futuro inalcançável para os destituídos daquele tempo. 
$\mathrm{O}$ problema era a urgência. $\mathrm{O}$ argumento que tinha e que mantenho é o seguinte: se você chega numa família e percebe que ela não tem o que comer, primeiro, você dá comida e depois você passa para a solução do problema. Eu dava o exemplo tirado da classe média: você chega em casa e você descobre que o seu filho sumiu: você vai voltar para o trabalho? Não vai. Você larga tudo até encontrar o garoto e ai você vai continuar a sua vida. A situação da fome, eu vejo nesta condição, é uma emergência da emergência (SOUZA, 1996, p.171 b).

Pensar essas dimensões estrutural e emergencial de forma articulada consistiu uma das propostas mais importantes e menos compreendidas da Campanha, tanto pelos setores reacionários que a viam como avessa ao trabalho, como da esquerda que a percebia como assistencialista e desviante das "grandes questões".

O grande debate de Betinho era com os setores da esquerda que mantinham, em geral, a posição que Betinho já havia problematizado e, em grande medida, superado desde o exílio no Chile. Em outubro de 1994, os problemas de setores da esquerda que permaneciam com um discurso monocromático, de visão platônica e pseudo-revolucionária que era incapaz de pensar e agir no agora são problematizados:

Talvez nossa grande aprendizagem seja a de articular o emergencial com o estrutural, porque nós somos oriundos de uma extração da esquerda e a esquerda sempre pensou muito a longo prazo. Para a esquerda, o que vale, o importante, o fundamental é o campo estrutural. $\mathrm{O}$ emergencial é visto como uma espécie de acidente ou algo que não é de minha responsabilidade. Na verdade, era como se, na sociedade não houvesse o emergencial. $O$ emergencial era uma espécie de desastre. Não previsto. Eu, com a experiência dos últimos tempos, vejo que não sabemos nada sobre a emergência (...). Pois nós, com a Campanha Contra a Fome, descobrimos várias coisas. Em primeiro lugar, percebemos que o emergencial é a expressão do estrutural. Uma é a expressão da outra. Portanto, se queremos mudar o estrutural, precisamos atacar o emergencial (...). Não creio que possa haver alguma opção estrutural que não passe pelo hoje..., pelo aqui, pelo agora (SOUZA apud PLASENCIA, 1998, p. 68 e 69).

Pensar a emergência de uma nova sociedade, de um novo país passava por respeitar as etapas dessas mudanças. O grande debate de Betinho com os setores de esquerda que o acusavam de promover o assistencialismo, ou de supostamente se afastar das questões estruturais, remetia àquilo que ele havia em grande medida, superado em sua própria experiência, mas que permanecia em alguns que 
insistiam em conservar o pensamento acrítico e a crença de que as grandes mudanças eram incompatíveis com ações simples.

Este pensamento se caracterizava por ter pressa de chegar ao futuro. No entanto, como se poderia vislumbrar um futuro no trágico quadro social brasileiro do início da década de 1990 cuja miséria e indigência exprimiam a caminhada rumo a um grande naufrágio social e político? (SOUZA, 1994, p. 32 d).

A proposta de mudança de Betinho na Campanha passava pela superação das injustiças na estrutura econômica e social brasileira, tendo como parâmetro não apenas a disposição para superar tais injustiças, mas concretizá-la a partir da solidariedade.

Não pode existir democracia sem solidariedade, compreendida a alteridade como expressão de ação na vida social. Aí é que se encontrava a grande diferença da Campanha contra a fome em relação a uma ação assistencialista. Ela partia desse ponto, da solidariedade para a mudança na estrutura social. Betinho, em entrevista na televisão, observou da seguinte forma as diferenças da Campanha em relação às acusações de assistencialismo:

\begin{abstract}
Eu acho que o assistencialista não quer acabar com a miséria, ele quer perpetuá-la de outra forma. Na verdade ele é uma espécie de gigolô da miséria e não quer promover quem ajuda. Eu acho que a solidariedade é uma coisa completamente diferente. E foi exatamente a confusão que muita gente estabeleceu, entre uma coisa e outra, que nos prejudicou muito no inicio da campanha. Porque eu dizia assim: 'quem tem fome tem pressa' e se você não oferece comida a quem está morrendo de fome, não adianta você pensar na reforma estrutural daqui a dez anos porque não vai ter população para viver a reforma (PANDOLFI; GAZIR; CORREA, 2012, p. 167).
\end{abstract}

A grande inovação na filosofia da Campanha estava em chegar ao debate estrutural utilizando primeiro o itinerário da inconformidade com as injustiças e com a miséria observadas no período até o questionamento da superestrutura que corroborava tais injustiças. Por isso, Betinho ignorava as acusações de assistencialismo e imediatismo vindas da esquerda.

Sua divergência com o assistencialismo também pode ser encontrada ainda nos tempos de sua juventude, mais especificamente em sua atuação na Juventude 
Católica (JEC e JUC). Neste período, já exprimia inclinação à parcela progressista da Ação Católica, que estabelecia diferenciação entre uma proposta meramente assistencial e a defesa da emergência de uma sociedade fundada a partir da noção de solidariedade. Nesse sentido, pode-se compreender que, desde então, já estava claro para Betinho as profundas diferenças entre caridade e solidariedade:

\begin{abstract}
A substituição de caridade por solidariedade não é simplesmente uma questão semântica. É a substituição de ação de caráter assistencialista para a ação que busca autonomia do ser humano, trazendo a ideia de ação generalizada e impessoal que visa a emancipação dos indivíduos daquelas situações que levam à exclusão ou à marginalização. Enquanto a ética da caridade individual deixa inalterado o sistema de dominação que promove relações altamente desiguais, minorando apenas temporariamente as necessidades dos excluídos, a ética da solidariedade o potencial de conduzir à mudança social mais efetiva, na medida em que se busca, através da ação social impessoal, a promoção do ser humano em sua totalidade (PAIVA, 2003, p. 191 e 192).
\end{abstract}

Tal argumento alude também a um fato que chamava muito a atenção de Betinho, o qual ele considerava como um paradoxo de nossa sociedade, a saber, a existência, entre nós, de uma incrível disposição para pensar as mudanças e transformações sociais e o descompasso de sua implementação prática. No momento de projetar as mudanças, éramos muito profícuos, mas, na hora de tirálas do papel, de praticá-las, nos mostrávamos infrutíferos, acanhados, dizia Betinho.

A inclusão da Campanha como chamamento à ação buscava, em grande medida, partir desta problemática, pensando a transformação dos problemas estratégicos no mesmo plano dos urgentes, isto é, pensando uma nova teoria para a sociedade que começasse a ser posta em prática conjuntamente.

A proposta da Campanha, tão radical quanto qualquer discurso de transformação social, tinha como inovação fundamental a inclusão da solidariedade como pano de fundo da transformação e das ações simples, porém efetivas como caminho para as ações e transformações complexas. Acabar com a fome constituía o primeiro objetivo de uma proposta de radicalização da democracia, que implicava em fazê-la existir para todos, não apenas para alguns. 
Por isso, acabar com a fome não é só dar comida, e acabar com a miséria não é só gerar emprego; é reconstruir radicalmente toda a sociedade, começando por incorporar agora 32 milhões de seres humanos ao mapa da cidadania. Assim como a miséria foi sendo construída com a indiferença frente à exclusão e à destruição de pessoas, a negação da miséria começa a se realizar com a prática cotidiana, ampla e generosa da solidariedade (SOUZA, 1994, p. 24).

O que se insere nesta discussão vai além da dicotomia emergencial x estrutural. Encontra-se, aqui, o projeto de construção de outra sociedade. Este projeto se mostrou inovador por ser diferente de outros que tinham o intento de mudar a sociedade, porque começava por agir com o efetivo apoio da sociedade. Ele não falava em nome da sociedade como tantos outros movimentos. $\mathrm{O}$ projeto foi abraçado por ela como nos revelam a pesquisa IBOPE, realizada à época, e as correspondências da população enviadas a Betinho.

Por fim, Betinho escreve em artigo publicado no mesmo período o resumo desta acusação que, no entanto, se localizou muito mais nos círculos partidários e ideológicos, não atingindo a sociedade que majoritariamente apoiara e abraçara a Campanha:

A campanha demonstrou que é possível distinguir assistencialismo de solidariedade humana. Que para pescar é preciso estar vivo. Que a solidariedade humana é fundamental na emergência dos que morrem de fome enquanto aguardam a materialização das propostas de mudanças de estruturas. E essas reformas estruturais só acontecem quando as mudanças do dia a dia ocorrem pela ação das pessoas. Mais do que isso, a campanha ganhou a alma e a mão da população brasileira, abrindo as duas para a solidariedade (SOUZA, 1994, p.41 c).

A Campanha, que tantas vezes teve de lidar com críticas que a associavam a uma ação assistencialista, foi capaz de estabelecer diferenças fundamentais entre o conceito de solidariedade e assistencialismo, cuja ideia pressupõe favor, hierarquia e clientela, aspectos que não se associavam à natureza da Campanha contra a fome. Pois, o que perpassava a relação entre quem dava e quem recebia era regido pela concepção da solidariedade como combustível da cidadania (LANDIM, 1998, p. 245). 
Para além das opiniões expostas por ambos os lados, a simples existência desta polêmica possibilitou o debate em torno da Campanha, estimulando debates, declarações, e centenas de textos de intelectuais sobre o tema (LANDIM, 1998, p. 245).

Além do fato de que a existência deste debate foi importante também para o processo de expansão e exposição do tema, sobretudo em relação à miséria e à desigualdade que, na década de 1990 ainda não figura como prioridade na agenda social e política brasileira. Os impactos da Campanha, ainda que indiretos, contribuíram para fortalecer a agenda social em nossa sociedade, especialmente num momento em que a agenda econômica parecia dominar o conjunto das preocupações.

\subsection{Consequências, desdobramentos e legados da Campanha para a relação Estado x Sociedade no Brasil}

Experimentou-se em terras brasileiras a construção de uma organização social em que o Estado, mesmo sendo muitas vezes distante dos problemas locais, se constituiu como expressão primaz na organização social. Se colocados lado a lado, Estado e sociedade, é possível perceber que, historicamente há predominância do primeiro em relação ao segundo, sendo esta, incompleta e subordinada aos ditames daquele.

E não raro, as mudanças realizadas pelo Estado e na esfera do Estado guardavam pouca ou nenhuma relação com o contexto da sociedade, fazendo com que as páginas da história brasileira fossem contadas em contextos distantes dos vivenciados pela sociedade (CARVALHO, 1987).

Os capítulos mais importantes de nossa história pós 1500 foram escritos, em geral, pela mão do Estado, de forma quase solitária: Independência, República, 
garantia dos direitos trabalhistas ${ }^{24}$ (CLT). Diante do Estado, a sociedade representava um elemento minúsculo, frequentemente compreendido como subordinada a ele.

Mesmo no contexto dos movimentos de reivindicação política, o lugar de destaque, o lócus fundamental para as mudanças, era o Estado. Com exceção do movimento anarquista que teve forte presença nos movimentos de reivindicação do início do século XX, os demais movimentos, em geral, olhavam para o Estado como a "menina dos olhos" das transformações.

Como visto no capítulo inicial, a própria experiência de Betinho é pontuada por esta questão. A forma mais paradigmática desta análise encontra-se no contexto anterior a sua saída da Ação Popular que junto a algumas centenas de militantes, no auge dos anos de chumbo da ditadura, ainda assim, acreditavam ter condições de promover a tomada do Estado brasileiro.

Estas observações ilustram como, no Brasil, a sociedade foi percebida de forma desproporcional em relação ao Estado. Nesse sentido, um dos legados mais relevantes de Betinho e da Campanha da Ação da Cidadania é o de trazer a sociedade como protagonista de um processo social, de fazê-la compreender sua dimensão e seu lugar.

Ela constitui uma das mais importantes ações de movimentos que possuíam uma proposta efetiva de transformação social, cuja atenção e organização de seu discurso fugia da órbita do Estado, atribuindo centralidade inédita à força de mobilização da sociedade e para a sociedade. A mudança do Estado seria consequência da transformação da sociedade.

Seu discurso, de certa maneira, alcançou êxito devido ao contexto histórico, em que havia a demanda por vozes que aglutinassem a insatisfação e a desconfiança que o Estado gerara na população. O contexto do final da década de 1980 e início

\footnotetext{
${ }^{24}$ Consolidação das Leis Trabalhistas, promulgada pelo governo em 1 o de maio de 1943, foi fruto de décadas de lutas do insipiente movimento operário brasileiro, que se desenvolveu nas primeiras décadas do século $X X$, a partir da influência dos imigrantes sobretudo italianos que traziam forte influência do movimento anarquista. No entanto, apesar de gestada pelos movimentos de trabalhadores, esse conjunto de direitos só foi reconhecido quando legitimado pelo Estado, reconhecendo e garantindo alguns direitos dos trabalhadores por meio desta lei.
} 
dos anos 90, a despeito da redemocratização, tinha ainda a viva lembrança do Estado opressor e totalitário da ditadura e de um Estado corroído pelo enorme arrocho lançado, sobretudo, aos setores mais empobrecidos no governo Sarney, além do surgimento de denúncias de corrupção e do desencantamento com o governo do presidente Collor cujo desfecho foi a cassação de seu mandato.

As soluções tradicionais ${ }^{25}$ vindas do campo da esquerda enxergavam, em geral, somente o Estado como caminho para a efetivação das mudanças. A singularidade da Campanha da Ação da Cidadania esteve em ocupar um espaço até então pouco explorado e que possuía uma potencialidade para consolidar a força de mobilização da sociedade como base para promover mudanças, inclusive no próprio Estado.

Ao fixar o eixo de suas preocupações na sociedade, Betinho e a Campanha da Ação da Cidadania mobilizaram uma força em potencial, que já havia demonstrado nas campanhas favoráveis ao fim da ditadura, nas diretas e no impeachment como a sociedade possuía uma força capaz de promover mudanças e que poderia ser utilizada com mais frequência.

Dessa forma, se era verdade que a insatisfação e a descrença da sociedade aumentavam quanto às organizações político-partidárias e as esferas institucionalizadas, é igualmente notável que a capacidade de indignação da sociedade não se encerrava com tais desconfianças.

Apesar de o assunto merecer reflexão mais aprofundada, pode-se afirmar que, ao longo das últimas duas décadas - ainda que a descrença quanto à política partidária e o distanciamento das instituições da sociedade e até mesmo de alguns setores dos movimentos sociais tradicionais que haviam perdido muito de sua capacidade de mobilização, por conta da ligação orgânica e institucional com o governo, sobretudo, os movimentos sindicais e estudantis (CUT e UNE) desenvolveram-se novas formas de mobilização com dinâmicas distintas.

\footnotetext{
${ }^{25}$ a mais em voga no momento, consistia na emergência de governos de esquerdas para um caminho que buscasse as transformações pela via eleitoral. No Brasil, ela se concentrava em Lula e no PT que tinha sólida base nos movimentos sociais, associações sindicais e círculos intelectuais
} 
Estruturar o centro de suas ações e atenções na sociedade, à margem dos canais institucionais de participação, vistos com desconfiança por alguns setores de movimentos políticos e sociais, permitiu à Campanha da Ação da Cidadania captar, em boa medida, um sentimento já presente na sociedade. Hoje, vinte anos depois, pode-se observar que muitos dos aspectos que caracterizaram as manifestações (ou jornadas) de junho de 2013 refletiam, em alguma medida, um sentimento semelhante ao de uma juventude que não se sentia representada por partidos políticos ou instituições tradicionais.

A Campanha, que nasce como resultado do Movimento pela Ética na Política, o qual propunha uma nova relação do Estado com a sociedade, contribuiu também para a modificação do universo simbólico no sentido de incluir novas formas de organização e de contestação política, cujas instituições tradicionais (partidos, governo, parlamento, sindicatos) foram substituídas por campanhas em que não figuram líderes ou mandatários. Este tipo de organização nos ajuda a pensar os novos movimentos sociais, sobretudo as jornadas de junho que traziam uma agenda com algumas semelhanças, sobretudo na recusa às lideranças tradicionais.

Analisando o perfil geral dos jovens brasileiros que participaram dos protestos pelo Brasil em 2013, Gohn (2014) observa como a agenda comum entre eles se concentrava numa nova relação com o Estado a partir de um tipo, pouco comum, de organização descentralizada, sem estruturas hierárquicas rígidas:

\begin{abstract}
Eles querem outro país, onde a ética e a política andem juntas. Querem uma revolução na forma de operar a política(...) Querem mudanças na política via atuação diferenciada do Estado no atendimento à sociedade(...). Não confiam na política atual nem nos partidos. Não se sentem representados no plantel politico institucional existente (...). A linguagem política dos manifestantes é outra. Seus códigos não se enquadram em planilhas, organogramas, planejamentos, siglas de planos e projetos (GOHN, 2014, p.65).
\end{abstract}

A criação de formas específicas e inéditas de organização e mobilização desenvolvidas ao longo da experiência da Campanha da Ação da Cidadania permitiu à sociedade pensar formas de legitimidade e representatividade distintas das modalidades clássicas de representação por delegação. Sua organização descentralizada e flexível incentivou e empoderou os indivíduos, que percebiam 
poder participar e intervir sem estarem subordinados a autoridades hierárquicas (LANDIM, 1998, p. 251).

A experiência da Ação da Cidadania vai, então, muito além de suas ações na década de 1990. Ela deixa um legado para a mobilização da sociedade mais profundo e complexo. Pensar a mobilização a partir da sociedade com formas de organização pouco usuais; reivindicar do Estado e de suas instituições uma postura uma postura ética como elemento necessário às transformações sociais; pensar a mudança da estrutura social a partir da força de mobilização da sociedade, constituem os elementos mais importantes no conjunto dos legados da Campanha da Ação da Cidadania. Legados que encontram-se indissociados da biografia de Betinho. 


\section{Conclusão}

A escolha do tema desta dissertação surgiu recentemente, devido à experiência do conjunto das manifestações de 2013 que constituiu interesse significativo, não apenas por contrariar qualquer previsão sociológica sobre tais ações, mas porque pudemos testemunhar os eventos.

Passados os eventos de maior amplitude, uma questão particularmente chamou atenção: a significativa rejeição dos manifestantes quanto à presença de partidos políticos. Se num primeiro momento os gritos "sem partido, sem partido" soaram com relativa desconfiança, os meses seguintes levaram à reflexão sobre este comportamento.

Foi a partir do encontro com a biografia de Betinho escrito por Carla Rodrigues que essas questões começaram a fazer sentido. Surgiu não apenas a certeza do tema desta dissertação, mas também a percepção de como o estudo da trajetória de Betinho e da Campanha da Ação da Cidadania poderiam trazer elementos para compreender algumas das questões presentes nos protestos de 2013.

Reexaminar a experiência da Ação da Cidadania com as ferramentas que dispõe o conhecimento sociológico ajuda-nos a pensar como ela oferece meios para compreender as mudanças nas dinâmicas de contestação política, assim como a emergência de novas formas de representatividade.

Como ao propor uma nova tipologia de engajamento político, que se mobilizava orientada por questões de responsabilidade para com o outro e com a coletividade, não necessariamente ou diretamente orientada por uma plataforma político-partidária específica, a Campanha realizou um exercício de sensibilização mostrando o desgaste das formas tradicionais de ação política, aquelas referidas à política partidária tradicional.

Buscar entender a Campanha e seus efeitos para além da mobilização de doação de alimentos foi o elemento buscado neste trabalho. Nesse sentido, algumas das questões que se buscou responder foram as seguintes: 1) de que 
maneira a Campanha contribuiu para influenciar as formas de ação política na sociedade? 2) população compreendeu a mensagem fundamental da Campanha a que se propunha, isto é, que para resolução da natureza dos problemas era necessário ir além da doação de alimentos?

Tomando estas duas questões como provocação à reflexão, deve-se então, problematizar as novas formas de ação política na sociedade animadas pela Campanha, assim como as demais implicações para além da doação de alimentos.

De maneira geral, observa-se que uma das influências mais significativas da Campanha da Ação da Cidadania foi a "criação", a "produção" de novos militantes. Ao expor o problema da miséria e da fome, ela fez um chamado à sociedade a quesionar-se sobre o escândalo que era a questão da miséria e da exclusão. Então, uma inovação de ação política, visto aqui como um de seus grandes legados foi o de retratar para um contingente muito maior de pessoas o tamanho dos problemas sociais brasileiros.

Em relação à segunda questão, as correspondências analisadas ajudaram a confirmar a hipótese inicial deste trabalho, a de que a população que se propôs a ajudar na doação de alimentos compreendeu em grande medida a mensagem fundamental da Campanha, ou seja, que a doação de alimentos constituía apenas o primeiro e mais urgente passo em direção à transformação social. Como visto em diversas correspondências, ao indicar uma série de soluções e sugestões, as pessoas, em geral, mostraram ter assimilado um dos pressupostos mais fundamentais da Campanha: a resolução dos problemas sociais, e modificação da estrutura social iam muito além da doação de alimentos. Nesse sentido a Campanha foi vitoriosa pois conseguiu mobilizar as pessoas para a gravidade da coexistência com a miséria e a desigualdade.

Neste trabalho, buscou-se identificar como os aspectos fundamentais da Campanha, que iam além da doação de alimento, tiveram a perspicácia de compreender um movimento, um desejo de mudança e de dialogar com a sociedade utilizando uma linguagem acessível e convergente com seus anseios. 
Nesse sentido, para pensar as ideias fundamentais da Campanha tornou-se imperativo buscar na biografia de Betinho a origem de tais mudanças. Apesar de, em alguma medida a importância da prática cidadã constituir aspecto para a organização social e da questão da necessidade da superação das desigualdades já estarem presentes em Betinho desde a juventude, até o exílio, elas eram buscadas priorizando a via do Estado. As mudanças que aparecem como fruto da compreensão da necessidade de uma nova tipologia de ação política que - anos depois se materializaria na Campanha - surgem a partir de seu exílio no Chile, experiência fundamental para compreender como a sociedade civil passa a ter no pensamento de Betinho, importância cada vez maior.

Tal como observado no primeiro capítulo, Betinho migra de uma visão de ação política, na qual a mudança era percebida como um caminho traçado unicamente pela via do Estado, para uma visão que só com a participação cidadã da sociedade se pode realizar mudanças significativas.

No conjunto dessas mudanças, Betinho passa a se identificar como democrata, passando a reivindicar uma ideia de democracia desenvolvida por ele em que as noções de solidariedade, participação, liberdade e sobretudo cidadania se constituem como elementos fundamentais de sua concepção de democracia.

A importância da sociedade civil como instância de ação social e política surge no horizonte de Betinho como aquela que mais se aproxima de uma concepção de democracia fundada na cidadania, na participação. A essencial participação da sociedade na Campanha da Ação da Cidadania revelou como ela constituiu um momento de cristalização dessa concepção.

Finalmente, o exame das correspondências da população enviadas a Betinho, de maneira geral, mostrou como as pessoas abraçaram a ideia da Campanha e como também queriam agir, "fazer alguma coisa" em meio ao escândalo da miséria e da desigualdade abissal que se faziam presentes na sociedade brasileira.

Ao longo deste trabalho, que se propôs a investigar a natureza, o conteúdo e as proposições da Campanha da Ação da Cidadania, tornou-se imperativo, para compreendê-la em sua totalidade, a necessidade de relacioná-la à própria 
experiência de Betinho que, ao longo de sua vida como militante, teve momentos bem definidos em sua forma de ação e compreensão política.

A campanha, nesse sentido, representa a coroação, o ponto alto de uma nova estratégia de ação política. Colocada no eixo central de sua ação, a força da sociedade revela que a ação política diferenciada, à margem do universo das organizações estruturadas de maneira vertical ou com discurso salvacionista, a Campanha revelou como, a partir da sociedade, se poderia transformar o país.

Aparece em seu caminho a noção de democracia, uma democracia que além de representativa, poderia ser participativa e constituída pelos valores da solidariedade, um ideal de democracia que, mesmo sendo fundamentalmente utópica por nunca estar completa, só poderia existir se fosse para todos, sendo incompatível com a exclusão.

Nesse sentido, a Campanha da Ação da Cidadania contra a Fome, a Miséria e pela Vida, na década de 1990, encontrava-se inexoravelmente inserida neste contexto. Ela tinha como pano de fundo o chamamento à defesa da criação de uma sociedade que integrasse os princípios e os requisitos elencados por Betinho para ser efetivamente democrática.

A Campanha, que inicialmente propunha a reunião de esforços para encarar de forma direta o problema urgente da fome e da miséria no país, não se bastava nesta agenda inicial. A Campanha contra a fome era intrínseca à inclusão dos setores historicamente excluídos. Mais que a fome, seu horizonte buscava pôr fim a uma sociedade excludente:

\begin{abstract}
Se o tema inicial da reinserção do Betinho no cenário político brasileiro foi o da fome e, com ele, o da solidariedade, logo se acrescentaram o da terra e o emprego. Resgatava-se uma parte substancial do que o Brasil tinha como dívida histórica acumulada com a grande maioria de sua população, recicladas de forma a lutar por sua realização. Não por acaso, as reivindicações do Betinho se encontravam com as do Movimento dos Sem Terra, esse movimento no qual os mais alijados da vida social e política brasileira começam a expressar seus direitos básicos (SADER, 2000, p. 344).
\end{abstract}

Essa finalidade é buscada por um caminho diferente, não mais o da pura e simplesmente tomada do Estado, mas da conquista da sociedade, pois era somente 
a partir dela que se poderiam realizar as mudanças fundamentalmente radicais, inclusive no Estado.

Nesse percurso, surgem na análise da Campanha duas convergências que se colocam como um interessante exercício de reflexão sobre sua experiência: primeiro, sua forte relação com o estímulo à ação política por meio de canais até então pouco explorados, como a participação direta pela sociedade, sem necessitar de instituições tradicionais. A segunda, também relacionada à primeira, em que se torna impossível analisá-la sem levar em conta a biografia de Betinho, considerando como fundamental o movimento de revisão de suas ideias realizado no período do exílio para compreender as bases de seu pensamento que culminou na realização da Campanha da Ação da Cidadania.

Muito além de uma campanha de doação de alimentos, ela significava a proposta de edificação de um outro projeto de sociedade, onde a solidariedade constituía o alicerce da vida social. A democracia constituía para Betinho um projeto contínuo, mas sobretudo, onde todos, indiscriminadamente, teriam seus direitos mais fundamentais garantidos. A Campanha Contra a Fome constituiu a materialização do pensamento de Betinho, de ação e de busca por um fazer quase utópico que tinha início nas ações simples.

Analisar a Campanha em todas as suas dimensões, assim como em seus pormenores constituiria um exercício demasiado grande e pretensioso. Portanto, o objetivo foi o de buscar concentrar-se na experiência da Campanha como uma forma de ação política que ia além da proposição do emergencial, mas que almejava uma proposta de vivência democrática.

O desenvolvimento da crença na importância do engajamento da sociedade civil no processo de reivindicação política e consequentemente na mudança social, da qual a campanha se fez como um movimento de ação concreta, não pode ser devidamente compreendido se não considerada a experiência de Betinho e o exercício de reavaliação de suas ações após o exílio.

O exercício de análise sobre a experiência da Ação da Cidadania conduz-nos à experiência de Betinho, em que a observação da sociedade brasileira, muitas vezes 
tida como acomodada, não condiz com a realidade, revelando que ela sempre esteve reelaborando e buscando novas formas de reivindicação. $\mathrm{O}$ mérito de Betinho em identificar novas possibilidades de ação política foi um dos temas no qual este trabalho procurou se debruçar. 


\section{Referências bibliográficas}

AVRITZER, Leonardo Além da dicotomia Estado/Mercado: Habermas, Cohem e Arato, in: "Revista novos estudos /CEBRAP", 36, Julho de 1993, São Paulo, pp. 213-222.

BOBBIO, Norberto 0 conceito de sociedade civil, 3a reimpressão, ed. Graal, Rio de Janeiro, 1984.

BOMENY, Helena Darcy Ribeiro: sociologia de um indisciplinado, ed. UFMG, Belo Horizonte, 2001.

Salvar pela escola: Programa Especial de Educação, in: Marieta de Morais Ferreira (Org), "A força do povo: Brizola e o Rio de Janeiro", ALERJ/CPDOC - FGV, Rio de Janeiro, 2008.

CARVALHO, José Murilo Os bestializados: o Rio de Janeiro e a República que não foi, 3aㅡ ed., Ed. Companhia das Letras, São Paulo, 1987.

Cidadania no Brasil: o longo caminho, 16 ${ }^{\mathrm{a}} \mathrm{Ed} ., \mathrm{Ed}$. Civilização Brasileira, Rio de Janeiro, 2013.

COSTA, Sergio As cores de Ercília: esfera pública, democracia, configurações pós nacionais, Ed. UFMG, Belo Horizonte, 2002.

COUTINHO, Carlos N. Gramsci: um estudo sobre seu pensamento político, ed. Civilização Brasileira, Rio de Janeiro, 1999.

CPDOC/FGV, Centro de Pesquisa e Documentação - Fundação Getúlio Vargas, Arquivo pessoal Herbert de Souza- Betinho. 
FERNANDES, Thiago Faça o que eu digo, não faça o que eu faço: o debate sobre o CIEP na sociedade brasileira, monografia em Ciências Sociais, Departamento de Ciências Sociais, PUC-Rio, 2011.

FICO, Caros Ibase: usina de ideias e cidadania, Ed. Garamond, Rio de Janeiro, 1999.

FREIRE, Américo O. G. Intelectuais, democratização e combate à pobreza no Brasil contemporâneo, in: Revista Brasileira de História, vol. 33, no 65, São Paulo, 2013.

GOHN, Maria da Glória Novas teorias dos movimentos sociais, ed. Loyola, São Paulo, 2008.

Movimentos sociais e redes de mobilizações civis no Brasil contemporâneo, $7^{a}$ ed., Ed. Vozes, Petrópolis, 2013.

, Manifestações de junho de 2013 no Brasil e praça dos indignados no mundo, Ed. Vozes, Petrópolis, 2014.

GONTIJO, Ricardo Sem vergonha da utopia: conversas com Betinho, Ed. Vozes, Petrópolis, 1988.

HABERMAS, Jurgen Mudança estrutural na esfera pública: investigações quanto a uma categoria de sociedade burguesa, Ed. Tempo brasileira, Rio de Janeiro, 1984.

Três modelos normativos de democracia, in: Lua Nova: revista de cultura e política, n‥36, 1995 
HIRSCHMAN, Albert As paixões e os interesses: argumentos políticos a favor do capitalismo antes de seu triunfo, Ed. Record, Rio de Janeiro, 2002.

LANDIM, Leilah Notas sobre a Campanha do Betinho: ação cidadã e diversidades brasileiras, in: Leilah Landim (Org.), "Ações em sociedade: militância, caridade, assistência, etc", ed. Nau, Rio de Janeiro, 1998.

LIMA NETO, Fernando Cardoso O sentido das ONGs no Brasil: justiça social, filantropia e ecologia, Tese de doutorado em Sociologia, IFCS UFRJ, 2013.

MAGALHÃES, Rosana Enfrentando a pobreza, reconstruindo vínculos sociais: as lições da Ação da Cidadania Contra a Fome e a Miséria e pela Vida", in: Cadernos de saúde pública, vol.18, Rio de Janeiro, 2012.

MAQUIAVEL, Nicolau O príncipe, Ed. Martin Claret, São Paulo, 2006.

MARX, Karl; ENGELS, Friedrich A ideologia alemã, Ed. Boitempo, São Paulo, 2007.

MARX, Karl 018 brumário de Luis Bonaparte, Ed. Boitempo, São Paulo, 2011.

Critica da filosofia do direito de Hegel, $2^{\underline{a}}$ ed., Ed. Boitempo, São Paulo, 2010. 
MOREIRA NETO, Estevam A. Sobre a sociedade civil em Hegel, Marx e Grasmci, in: Anais do IV simpósio Lutas sociais na América Latina UEL, Londrina, 2010.

NAKANO, Maria; ROITMAN, Ari (Orgs) Estreitos nós: lembranças de um semeador de utopias, Ed. Garamond, Rio de Janeiro, 2001.

NAKANO, Maria Betinho: a trajetória do dogmatismo à democracia, in: Ligia Chiappini; Antonio Dimas; Berthold Zilly (Orgs.) Brasil, país do passado?, Ed. Boitempo, São Paulo, p.322,- 331, 2000.

NOVAES, Rubens Novas possibilidades para o exercício da cidadania, in: Jayme Pinsky; Carla Bassanezi (Orgs), "História da Cidadania", Ed. Contexto, São Paulo, 2013.

NITSCH, Manfred De trabalho e luta a cidadania e democracia: "aggionamento" da esquerda, in: Ligia Chiappini; Antonio Dimas; Berthold Zilly (Orgs.) Brasil, país do passado?, Ed. Boitempo, São Paulo, p.332-340, 2000.

PAIVA Angela R. Católico, protestante, cidadão: uma comparação entre Brasil e Estados Unidos, Ed. UFMG, Belo Horizonte, 2003.

PANDOLFI, Dulce; GAZIR, Augusto; CORREA, Lucas (Orgs) O Brasil de Betinho, Mórula editorial - IBASE, Rio de Janeiro, 2012.

PANDOLFI, Dulce; HEYMANN, Luciana Um abraço Betinho, ed. Garamond, Rio de Janeiro, 2005.

PLASENCIA, Janett Ação da Cidadania - comitê Rio: uma experiência de educação na e para a cidadania, Dissertação de mestrado Departamento de Educação - PUC-Rio, 1998. 
POLANYI, Karl A grande transformação: as origens de nossa época, $2^{\mathrm{a}}$ ed., Ed. Campus/Elsevier, Rio de Janeiro, 2012.

PERLATTO, Fernando Habermas, a esfera pública e o Brasil, in: "Revista de estudos políticos", n4, 2012/1, Rio de Janeiro, pp. 78-94.

RODRIGUES, Carla Betinho - sertanejo, mineiro, brasileiro, Ed. Planeta, São Paulo, 2007.

SADER, Emir A vida e a morte de Betinho. Entre o Brasil solidário e o Brasil solitário, in: Ligia Chiappini; Antonio Dimas; Berthold Zilly (Orgs.) Brasil, país do passado?, Ed. Boitempo, São Paulo, p.341-346, 2000.

SANTOS, Milton Por uma outra globalização: do pensamento único à consciência universal, 19a ed., ed. Record, Rio de Janeiro, 2010.

SEMERARO, Giovanni A primavera dos anos 60: a geração de Betinho, Ed. Loyola, São Paulo, 1994.

SENNETT, Richard 0 declínio do Homem público: as tiranias da intimidade, Companhia das Letras, São Paulo, 1988.

A corrosão do caráter: consequências pessoais do

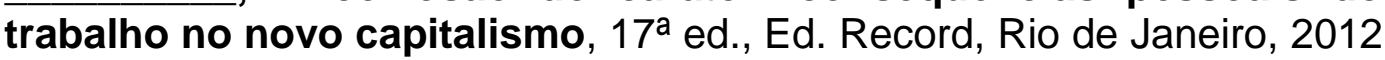
a. Juntos: os rituais, prazeres e a política da cooperação, $1^{1}$ ed., Ed. Record, Rio de Janeiro, 2012 b. 
SOUZA, Herbert de, Betinho - Depoimentos, in: CAVALCANTI, Pedro C. U.; RAMOS, Jovelino "Memórias do exílio: Brasil 1964 - 19??", Ed. Livramento, São Paulo, 1978.

, Construir a utopia: proposta de democracia, Ed. Vozes, Petrópolis, 1987.

A democracia no Brasil, in: Escritos indignados: democracia e neoliberalismo no Brasil, Ed. Rio fundo/IBASE, Rio de Janeiro, 1991.

Ação e reação contra a miséria, CPDOC/FGV, Arquivo Herbert de Souza, Caderno HS PI, 1993.04.22, 1993.

A Alma da fome é política, in: SOUZA, Herbert; RODRIGUES, Carla (Orgs.), "Ética e cidadania”, Ed. Moderna, São Paulo, 1994 a.

Opção pela sociedade, in: "Jornal da Cidadania", Ano I, no, Rio de Janeiro, setembro de 1994 b.

Pela ética no trabalho, in: SOUZA, Herbert; RODRIGUES, Carla (Orgs.), "Ética e cidadania”, Ed. Moderna, São Paulo, 1994 c.

O pão nosso, in: SOUZA, Herbert; RODRIGUES, Carla (Orgs.), "Ética e cidadania”, Ed. Moderna, São Paulo, 1994 d. 
A resposta da sociedade, in: SOUZA, Herbert; RODRIGUES, Carla (Orgs.), "Ética e cidadania", Ed. Moderna, São Paulo, 1994 e.

; RODRIGUES, Carla Ética e Cidadania, Ed. Moderna, São Paulo, $1994 \mathrm{f}$

, Democracia e cidadania, in: Democracia: cinco princípios e um fim, Carla Rodrigues (Org.), Ed. Moderna, São Paulo, 1996 a.

Janeiro, 1996 b.

No fio da navalha, Col. Quem é, ed. Revan, Rio de

TONET, Ivo Do conceito de sociedade civil, visualizado em 22/11/2014, disponível em: http://ivotonet.xpg.uol.com.br/arquivos/do conceito de sociedade civil.pdf, 2006.

WEBER, Max Os três tipos puros de dominação legítima, in: COHN, Gabriel, “Weber”, ed. Ática, São Paulo, 1986.

WEFFORT, Francisco Por que democracia?, Ed. Brasiliense, São Paulo, 1984.

WOLFE, Alan Três caminhos para o desenvolvimento: mercado, Estado e sociedade civil, in: "A democracia como proposta", IBASE, Rio de Janeiro, 1991. 